\title{
Interim Report on Development of a Model to Predict Dissolution Behavior of the Titanate Waste Form in a Repository and Compilation of Data from SPFT Ceramic Dissolution Tests
}

W.L. Bourcier

December 8, 1999

U.S. Department of Energy

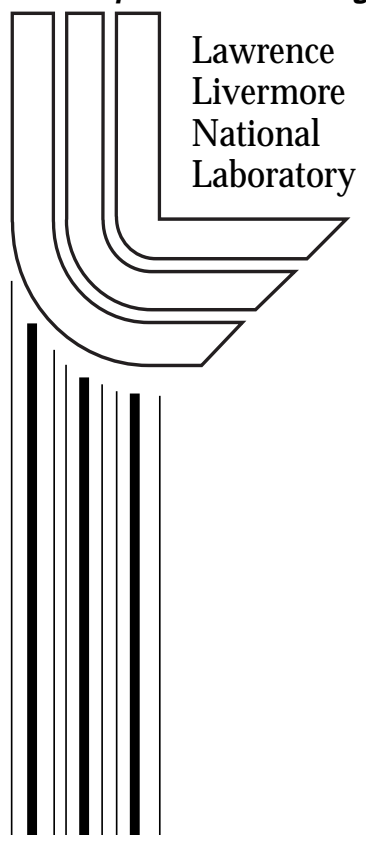




\section{DISCLAIMER}

This document was prepared as an account of work sponsored by an agency of the United States Government. Neither the United States Government nor the University of California nor any of their employees, makes any warranty, express or implied, or assumes any legal liability or responsibility for the accuracy, completeness, or usefulness of any information, apparatus, product, or process disclosed, or represents that its use would not infringe privately owned rights. Reference herein to any specific commercial product, process, or service by trade name, trademark, manufacturer, or otherwise, does not necessarily constitute or imply its endorsement, recommendation, or favoring by the United States Government or the University of California. The views and opinions of authors expressed herein do not necessarily state or reflect those of the United States Government or the University of California, and shall not be used for advertising or product endorsement purposes.

Work performed under the auspices of the U. S. Department of Energy by the University of California Lawrence Livermore National Laboratory under Contract W-7405-Eng-48.

This report has been reproduced directly from the best available copy.

Available to DOE and DOE contractors from the

Office of Scientific and Technical Information

P.O. Box 62, Oak Ridge, TN 37831

Prices available from (423) 576-8401

http://apollo.osti.gov/bridge/

Available to the public from the National Technical Information Service

U.S. Department of Commerce 5285 Port Royal Rd., Springfield, VA 22161 http://www.ntis.gov/

OR

Lawrence Livermore National Laboratory Technical Information Department's Digital Library http://www.llnl.gov/tid/Library.html 


\title{
Interim Report on Development of a Model to Predict Dissolution Behavior of the Titanate Waste Form in a Repository and Compilation of Data from SPFT Ceramic Dissolution Tests
}

\author{
William L. Bourcier \\ Lawrence Livermore National Laboratory
}

December 8, 1999. 



\begin{abstract}
Dissolution testing performed to date on a titanate waste form under development for plutonium immobilization reveals the following: (1) The wasteform is very durable. Many of the test results have shown the dissolution rate to be below detection or less than background levels of the constituent elements; (2) elemental release is non-stoichiometric with $\mathrm{Pu}, \mathrm{U}, \mathrm{Ca}$, and $\mathrm{Gd}$ released faster than $\mathrm{Ti}$ and $\mathrm{Hf}$ at most $\mathrm{pH}$ conditions; (3) dissolution rates measured in flow-through tests sometimes show a continuous decrease with time in tests of up to two years duration; (4) attempts to model the dissolution as a transport-controlled process with diffusion through a leached layer as the rate limiting mechanism show reasonable agreement at low $\mathrm{pH}$ conditions but poor agreement at neutral to alkaline pHs.
\end{abstract}

Based on present uncertainties in our understanding of rate control, we have provided conservative estimates of radionuclide release rates based on the fastest observed release rates measured in short-term tests. These dissolution rates under repository-relevant conditions are in the range of $10^{-3}$ to $10^{-6} \mathrm{~g} / \mathrm{m}^{2} /$ day.

\title{
I. Introduction
}

This report summarizes dissolution testing performed to date on a titanate ceramic waste form under development for the disposition of surplus plutonium. The test data are used to develop a mechanistic interpretation of the ceramic dissolution process, and to establish dissolution rates for use in performance assessment calculations of the ceramic waste form in the candidate Yucca Mountain repository. This report provides both release rates of radionuclides (and other elements) from the ceramic, and qualitative information on relative rates of release of fissile elements $\left({ }^{239} \mathrm{Pu}\right.$ and $\left.{ }^{235} \mathrm{U}\right)$ and neutron absorbers ( $\mathrm{Gd}$ and $\left.\mathrm{Hf}\right)$.

Because data collection is in progress, this paper serves as a status report of our understanding of the ceramic dissolution process. Our conclusions and recommendations are based on data obtained to date. We do not yet have tests with durations longer than about two years and these appear to not have yet reached steady state. We also have very little information on characterization of alteration layers that form on the reacted ceramic. The reason for this is that the alteration layers are extremely thin, on the order of tens of Angstroms in thickness, and analytical methods previously used to study, for example, spent fuel and glass alteration layers do not resolve the layers on the ceramics.

Characterization of these surface alteration layers is important for two reasons. The first is that the dissolution data suggest possible transport control of the dissolution rate of the ceramic, probably by diffusion of elements such as $\mathrm{U}$ and $\mathrm{Pu}$ through a Hf- and Ti-rich surface layer. It will clearly be important to document the existence of this hypothetical layer. The second reason is that the key performance assessment question for this waste form has to do with the potential for criticality. The ceramic itself will contain a small number of Curies relative to the other HLW forms slated for disposal in the repository, and its durability is orders of magnitude better than both borosilicate glass and spent fuel (Stout and Leider, 1998; Shaw, 1999). Absolute release rates of radionuclides are therefore not of great concern for repository safety analysis. The key question for this waste form has to do with separation of the actinides from the neutron absorbers and the potential for criticality. 
Therefore we need information that allows us to predict whether elements leached from the ceramic end up in the alteration layer, in secondary phases, as colloids, or in solution ${ }^{1}$. We need this information in order to predict whether there are scenarios in which significant accumulations of the fissile elements, in the absence of neutron-absorbing elements, could occur. For this reason, identification of how the actinides and fissile elements partition between solution, alteration layer, alteration phases, and colloids is critical.

In spite of these existing uncertainties involving release mechanisms and rate control, we have used the existing data to provide input for performance assessment. Where key questions remain unresolved, we make conservative assumptions to bound maximum possible dissolution rates, or maximum differences in dissolution rates of fissile elements vs. neutron absorbers. Our aim is to provide data for worst-case conditions, as well as most probable values. The analysis of worst-case scenarios can be used to guide future experimental and modeling work into potential problem areas.

\section{Summary of experimental results}

Several types of tests have been used to measure the durability of the titanate ceramic waste form. These include single-pass flow-through tests (SPFT), static tests with monoliths (MCC-1) and powders (PCT), and tests in which the ceramic reacts with water vapor at high temperatures (VHT). We have also performed tests with other repository materials present, such as the pressurized unsaturated flow test (PUF) and static tests, in which the ceramic is sandwiched between layers of high-level waste glass. Most of the discussion of test results here will focus on the SPFT tests because their purpose is to provide model parameters. The purposes of the other tests include determining the relative durabilities of differing product formulations, direct comparisons with other repository waste forms, formation of more substantial alteration layers to help in their characterization, and model validation. A discussion of these other test results will be limited to their implications for dissolution mechanism and determination of rate parameters.

The ceramic waste form to be used for Pu disposition contains several minerals (see Table 1) having average grain sizes on the order of 5-50 microns. This presents a problem in interpretation of dissolution test results because the elemental leach rates are made up of contributions from all the minerals in the ceramic that contain that element. For example, the observed uranium leach rate for the baseline ceramic is really the weighted sum of the $\mathrm{U}$ releases from pyrochlore, zirconolite, and brannerite. In the absence of other information, the relative amounts leached from each phase are not known. For this reason, we have also performed dissolution tests on single-phase materials, and intend to deconvolute the signal from the multi-phase ceramic using these results when the relevant tests have been completed. This condition should be kept in mind when comparing results of tests of different formulations. The bulk compositions of all the ceramics referred to in this report are given in Table 2.

\footnotetext{
${ }^{1}$ In this paper, "alteration layer" refers to a structurally intact surface layer that has been depleted in one or more elements due to selective leaching; "secondary phases" are phases which precipitate from material dissolved from the ceramic.
} 
Table 1. Dominant minerals present in ceramic waste form.

\begin{tabular}{|c|c|c|}
\hline Mineral & & Composition \\
\hline & Normative & In Waste From \\
\hline Zirconolite & $\mathrm{CaZrTi}_{2} \mathrm{O}_{7}$ & $(\mathrm{Ca}, \mathrm{Gd}, \mathrm{Pu})(\mathrm{Hf}, \mathrm{Pu}, \mathrm{U}) \mathrm{Ti}_{2} \mathrm{O}_{7}$ \\
\hline Pyrochlore & $\begin{array}{ll}------ \\
\end{array}$ & $(\mathrm{Ca}, \mathrm{Gd}, \mathrm{Pu})(\mathrm{Hf}, \mathrm{Pu}, \mathrm{U}, \mathrm{Gd}) \mathrm{Ti}_{2} \mathrm{O}_{7}$ \\
\hline Brannerite & $\mathrm{UTi}_{2} \mathrm{O}_{6}$ & $(\mathrm{Hf}, \mathrm{Pu}, \mathrm{U}) \mathrm{Ti}_{2} \mathrm{O}_{6}$ \\
\hline Rutile & $\mathrm{TiO}_{2}$ & $(\mathrm{Ti}, \mathrm{Hf}) \mathrm{O}_{2}$ \\
\hline
\end{tabular}

Another factor that complicated the interpretation of dissolution tests of this ceramic is its very low reaction rate. This increases the difficulty of performing dissolution tests, and necessitates maintaining low background contamination levels, and requires very low detection limits for the analytical equipment.

The low release rates also affect how we interpret the data. The dissolution rate of the typical pyrochlore-based ceramic at $90^{\circ} \mathrm{C}$ has been measured to be between $10^{-4}-10^{-2}$ $\mathrm{g} / \mathrm{m}^{2} /$ day. If this were uniform surface dissolution, the rate of removal of the surface layer would be between 6 and 600 Angstroms/month. (For comparison, the atomic radii of most atoms are on the order of 1 to 2 Angstroms.) This is an extremely low rate. It is possible that instead of dissolution of a homogeneous surface layer of ceramic, we are actually measuring dissolution from grain boundaries and disturbed surface material generated during grinding. Grinding of crystalline oxides is known to change the atomic structure of some of the outer-most atomic layers, which makes this material less durable because of an increase in dislocation density (Hochella, 1990; Velbel, 1986). This is analogous to the decrease in durability of glasses versus their crystalline counterparts. With less durable solids, dissolution of these low-durability sites shows up as an elevated pulse early in time that decays away to a level indicative of surface dissolution of bulk material. It may be that for these ceramics, even tests of several months duration continue to measure disturbed layer or grain boundary release rates, and that we have not yet seen in these tests true dissolution rates for the bulk material, which are the rates most relevant for predicting longterm behavior of the waste form in the repository. Such long-term rates would be expected to be slower than the rates measured in these tests.

Alternatively, because the ceramics are multi-phase, the short-term release may be dominated by one or more of the minor phases early on. As these phases disappear, the release rates slow down and give rise to the curvature of the release rate vs. time plots. This hypothesis is difficult to evaluate until we have completed our rate measurements for the individual phases. 
Table 2. Compositions of ceramics used in SPFT tests in element wt $\%$.

\begin{tabular}{|l|c|c|c|c|c|c|c|c|}
\hline & $\mathrm{A}$ & $\mathrm{B}$ & $\mathrm{C}$ & $\mathrm{D}$ & $\mathrm{E}$ & $\mathrm{F}$ & $\mathrm{G}$ & $\mathrm{H}$ \\
\hline & $\mathrm{Ce}-\mathrm{U}$ & $\mathrm{Pu}-\mathrm{U}$ & Pyrochlore & Zirconolite & $\begin{array}{c}\text { Brannerit } \\
\mathrm{e}\end{array}$ & Pu-84 & BSL3 & PY12 \\
\hline & LLNL & LLNL & LLNL & LLNL & ANSTO & ANSTO & PNNL & PNNL \\
\hline $\mathrm{Ti}$ & 20.61 & 21.52 & 21.7 & 21.28 & 22.29 & 19.7 & 24.78 & 23.91 \\
\hline $\mathrm{U}$ & 25.65 & 20.8 & 21.38 & 14.23 & 55.38 & & & \\
\hline $\mathrm{Pu}$ & -- & 10.5 & -- & -- & & 49.1 & -- & - \\
\hline $\mathrm{Ce}$ & 7.54 & & 6.86 & 5.19 & & & 21.85 & 28.8 \\
\hline $\mathrm{Hf}$ & 9.61 & 8.99 & 10.6 & 21.53 & & & 9.43 & 2.63 \\
\hline $\mathrm{Gd}$ & & 6.85 & 7.05 & 6.0 & & & 7.95 & 11.55 \\
\hline $\mathrm{Zr}$ & & & & & & & & \\
\hline $\mathrm{Ca}$ & 8.63 & 7.08 & 7.49 & 6.92 & & 8.2 & 8.2 & 5.88 \\
\hline $\mathrm{Mo}$ & & & & & & & 0.06 & 0.07 \\
\hline $\mathrm{O}$ & 27.96 & 24.26 & 24.92 & 24.85 & 22.33 & 23.00 & 27.73 & 27.16 \\
\hline
\end{tabular}

A related problem is that of contamination. Acidified samples of leachates from these tests can readily become contaminated in the laboratory. For example, a typical $\mathrm{Ca}$ concentration for a leachate is a few tens of parts per billion. For a five-milliliter sample, $20 \mathrm{ppb} \mathrm{Ca}$ would be generated by dissolution of a 20 -micron radius particle of calcium, a size well within the range of airborne dust particles. Clearly, contamination can be a problem, especially with more common elements. For this reason, we have not used calcium release rates from any of the tests to extract rate information. Calcium background levels are too high (i.e. Appendix C of Bakel et al., 1999c). Instead, we have used less common elements such as $\mathrm{U}, \mathrm{Pu}, \mathrm{Gd}$, and $\mathrm{Ce}$, which have lower blank levels because they are less common in the environment.

\section{Single-Pass Flow-Through Test Results}

These tests measure the release rates of elements dissolved from powdered ceramic into flowing $\mathrm{pH}$-buffered solutions. They are designed to measure the dissolution rate far from equilibrium where rates are not affected by saturation effects. This is done by adjusting the flow rate and surface area of the sample and is not always possible for low solubility oxides. They are not designed to mimic repository conditions. They are instead designed to extract model parameters for a kinetic model of ceramic dissolution. A more complete discussion of the SPFT method can be found in Appendix A of this report or Knauss and Wolery, 1986; McGrail, 1999, and Bourcier, 1998).

\section{Multi-Phase Ceramics}

Results for SPFT tests at different solution $\mathrm{pHs}$ on a pyrochlore-based Ce-surrogate ceramic ('A' in Table 2) are shown in Fig 1 . The tests were performed at $25^{\circ} \mathrm{C}$ in solutions with $\mathrm{pH}$ values of $2,4,6,8,8.7,10$, and 12 . The material contained dominantly pyrochlore (> 80 volume $\%$ ), with lesser amounts of zirconolite, brannerite and rutile. The plots are of normalized release rate $v s$. time. The normalized release rate is defined as:

$$
N R_{i}=\frac{C_{i} * Q_{i}}{S * m * X_{i} * \rho}
$$


where $C_{i}$ is the blank corrected concentration of element $i$ in the buffered leach solution, $Q$ is the solution flow rate, $S$ is the BET-measured specific surface area of the ceramic, $m$ is the mass of ceramic, $X_{i}$ is the weight fraction of element $i$ in the ceramic, and _is the density of the solution. Normalized rates are given in Table A3 in units of $\mathrm{g} / \mathrm{m}^{2} /$ day.

These data show that at $\mathrm{pH} 2$, release of all elements except $\mathrm{Hf}$ is nearly congruent. They all are released at about the same rate. This may indicate that the hydrolysis of the Ti-O bonds at the solution-ceramic interface is so rapid that a leached layer does not build up at the surface. A leached layer will form when some elements are relatively insoluble and are left behind on the surface, or that the Ti-O framework of the ceramic remains relatively intact and released elements must diffuse through it in order to be released. The normalized release rates are also nearly independent of flow rate, indicating their release rates are not solubility controlled. It follows from the definition of normalized release rate that an element whose release is solubility controlled (has a constant concentration in solution, $\mathrm{c}_{\mathrm{i}}$, regardless of flow rate) would have a normalized release rate value that correlates with the system flow rate. At both $\mathrm{pH} 2$ and 4, Hf exhibits this type of behavior, and may be solubility controlled. We would expect to see a Hf-rich surface alteration layer on the altered ceramic or precipitation of a Hf-phase in the system if this is true.

As the $\mathrm{pH}$ increases, the dissolution becomes more and more incongruent (Fig. 1). All the elements are released at differing rates. In many cases, their concentrations are below detection, especially $\mathrm{Ti}, \mathrm{Hf}$, and $\mathrm{Ce}$. These data suggest that the elements that are released more slowly are left behind in a leached layer, probably as a Ti- and Hf-enriched surface layer.

Note the large amount of scatter in the data for $\mathrm{Ca}$, which is probably due to contamination. Many $\mathrm{Ca}$ analyses had background corrections comparable to the measured values. The release data for $U$ appear to be the best in terms of reproducibility, consistent trends, and signal-to-noise ratio. $U$ is also generally one of the fastest released elements. For this reason we have used the $U$ release rates to calculate overall dissolution rates for the ceramic. 

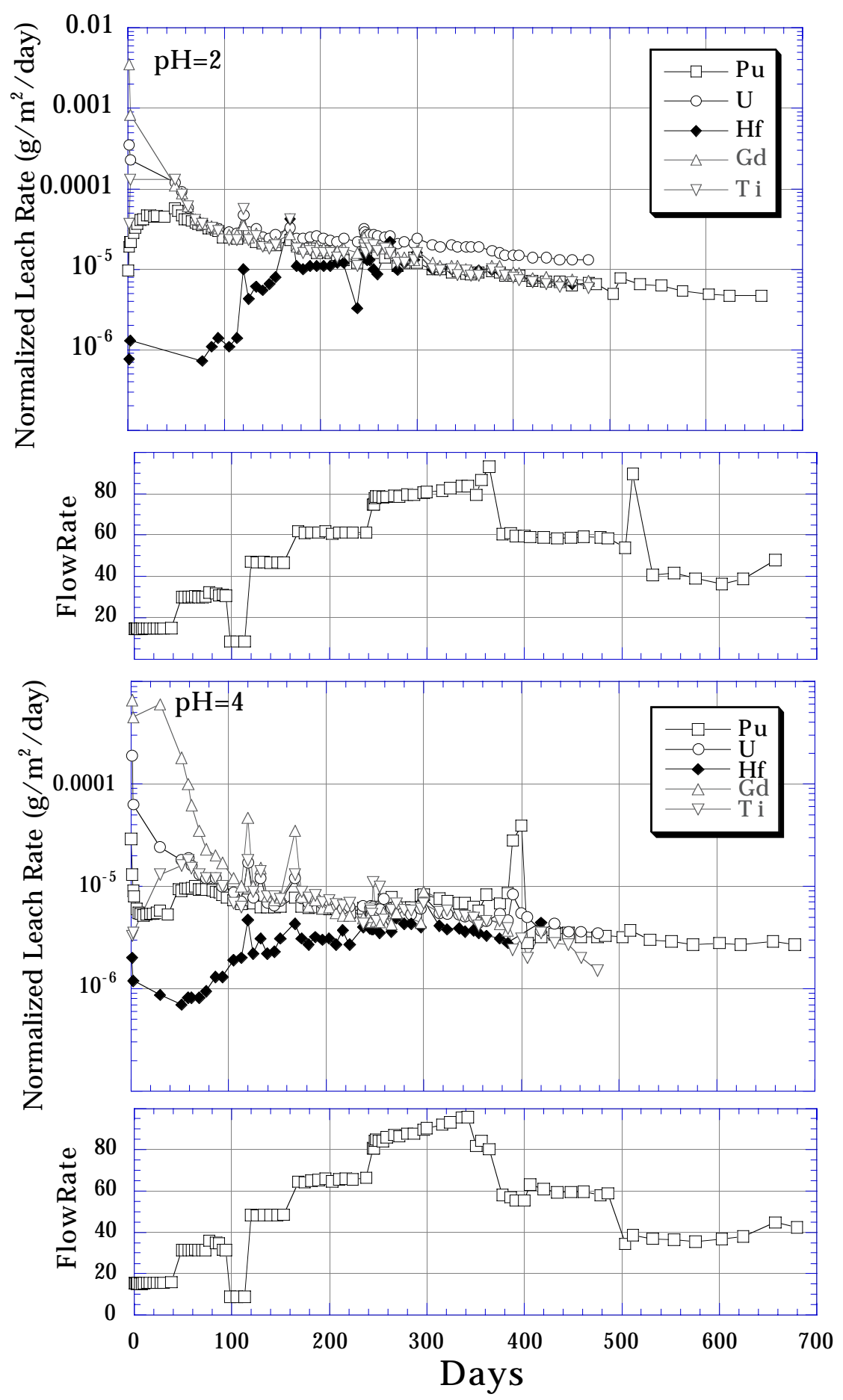

Figure 1. Normalized release rates $\left(\mathrm{g} /\left(\mathrm{m}^{2}\right.\right.$ day $\left.)\right)$ and flow rates $(\mathrm{mL} /$ day) for single-pass flow-through tests of a Cesurrogate pyrochlore-based ceramic formulation in $\mathrm{pH}$ buffer solutions from 2 to 12 . 

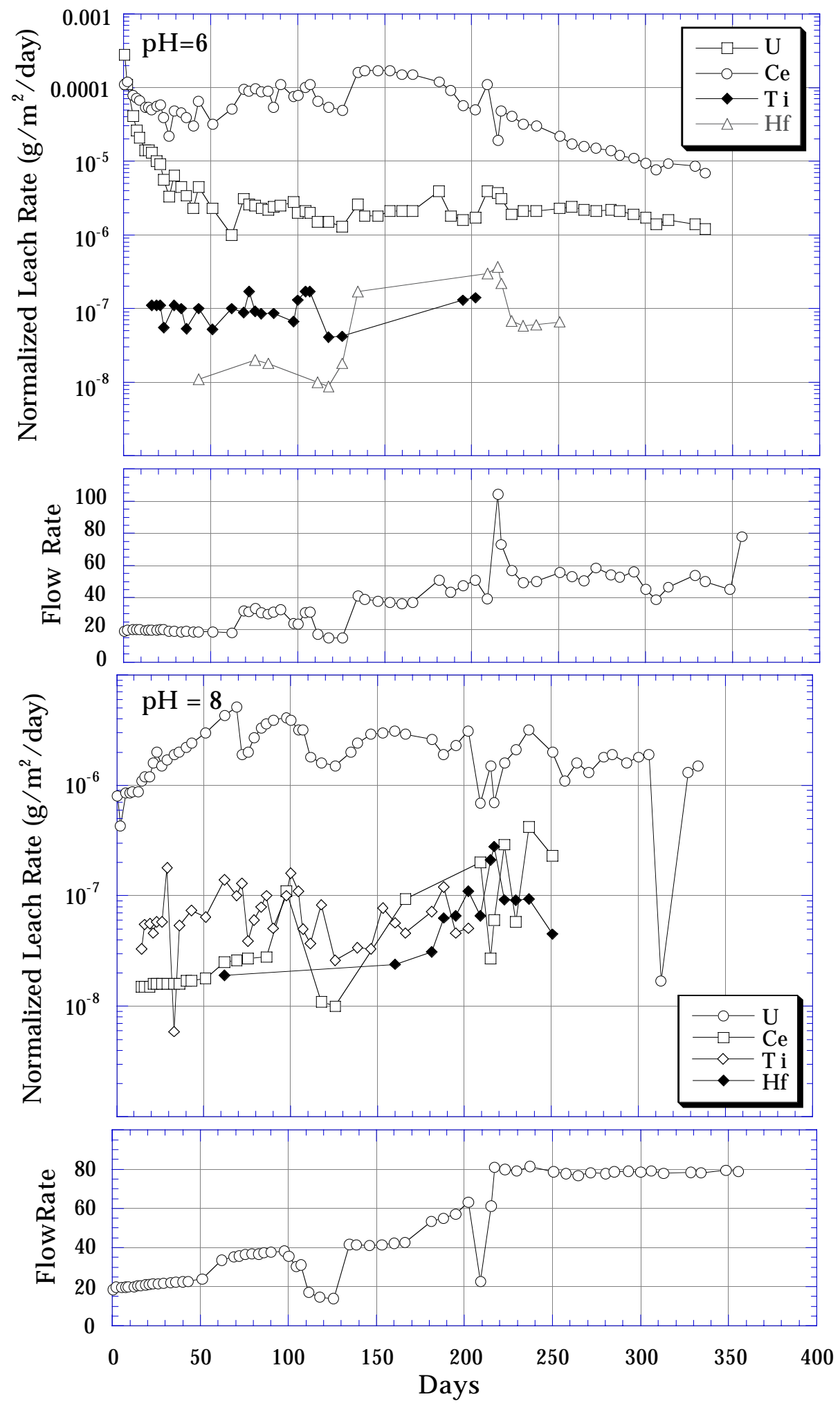

Figure 1. (cont.) 

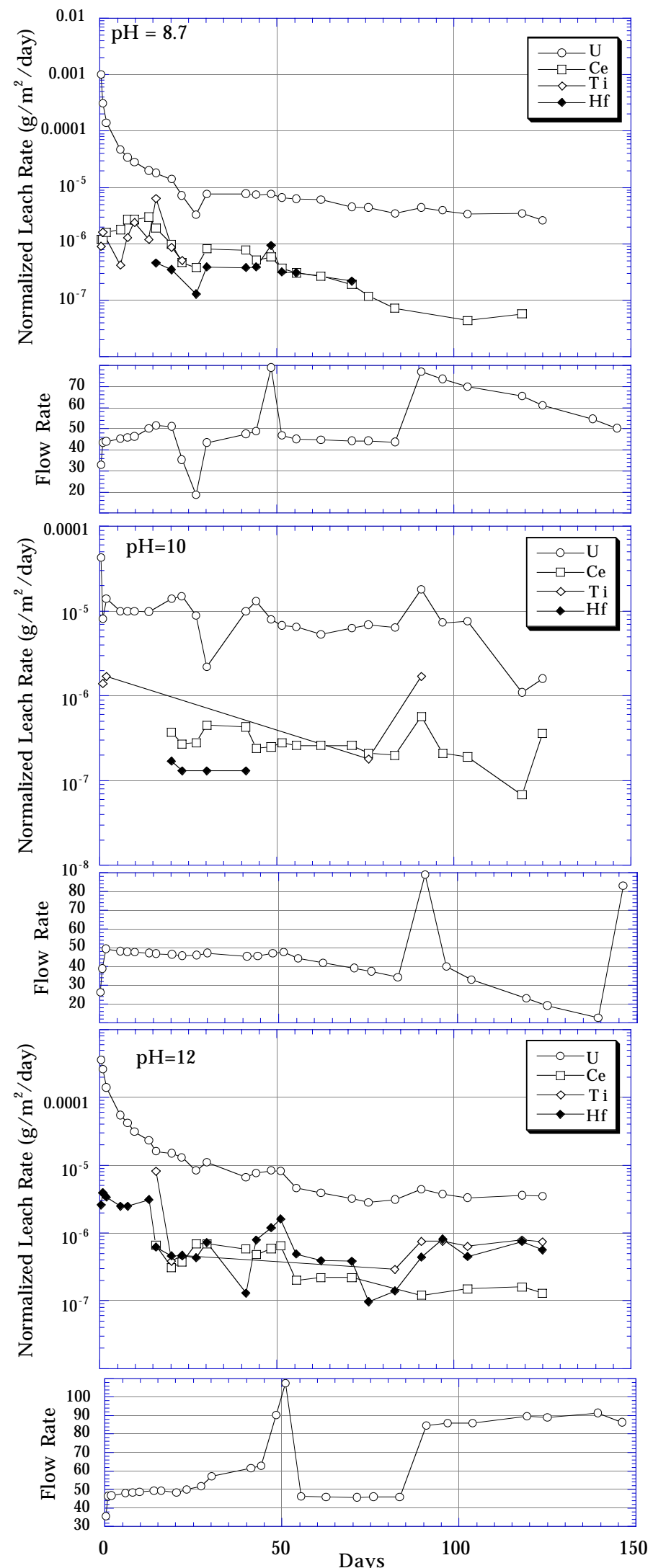

Figure 1. (cont.) 
The data also show a decrease in rate with time. This trend continues throughout the duration of the tests. This trend is also clear in two-year tests of U-Pu ceramic (composition B in Table 2) under similar test conditions in which release rates of both $\mathrm{U}$ and $\mathrm{Pu}$ continue to decrease over time (Fig. 2). Figure 3 which shows only the uranium release data from the $\mathrm{Ce}-\mathrm{U}$ tests of Figure 2 indicates that the dissolution rate is not a strong function of $\mathrm{pH}$, and further suggests that the rate dependence on $\mathrm{pH}$ gets smaller with time. A pH difference of 4 units ( $\mathrm{pH}$ of 2 to 6 ) changes the dissolution rate by a little less than a factor of ten. The dissolution rates of oxides for which the rate-limiting step for dissolution involves a surface reaction typically show a much greater dependence on $\mathrm{pH}$. For example, the HLW borosilicate glass dissolution rate changes by a factor of one thousand over the same $\mathrm{pH}$ range (Knauss et al., 1990). However, some silicates, such as albite, show about the same dependence of dissolution rate on $\mathrm{pH}$ as the pyrochlore-based ceramic (Knauss and Wolery, 1986).

To test the effect of anion content on dissolution rate, we used three different $\mathrm{pH} 12$ buffer solutions containing three types of anions. In addition to pure 0.1 molar $\mathrm{NaOH}$, we used solutions of carbonate and phosphate at the same $\mathrm{pH}$. Both carbonate and phosphate are strong complexing agents of actinides and rare earth, and could potentially affect the dissolution rates of the titanate ceramics. Figure 4 shows that over the 150 day time period of the tests, there appears to be no significant effect of the anions on dissolution rates at high $\mathrm{pH}$.

\section{$\underline{\text { Single Phase Test Results }}$}

The test results shown in Figs. 1 and 2 are for the multi-phase pyrochlore-based ceramics. Release rates for a given element therefore are the surface-area-weighted sum of the release rates from all the minerals that contain that element. To deconvolute these data, we are in the process of measuring dissolution rates of single-phase materials.

Figure 5 shows U-release rate data for single-phase pyrochlore, zirconolite, and brannerite at various temperatures after 4 weeks of reaction. We also include data from tests of the multi-phase ceramic at 25 and $90^{\circ} \mathrm{C}$. A comparison of the data for single-phase zirconolite and pyrochlore at 25,50 and $75^{\circ} \mathrm{C}$ show that pyrochlore is a factor of about 2-3 times less durable than zirconolite at $\mathrm{pH}$ values less than 8 , but has comparable durability above that $\mathrm{pH}$. A comparison of the data for the composite ceramics with the single-phase results at $25^{\circ} \mathrm{C}$ (Fig. 5a) shows comparable dissolution rates for both the single-phase and multiphase materials. This is consistent with the observations that the multi-phase ceramics are primarily pyrochlore and zirconolite, and that most of the uranium dissolved from all these materials originates in the pyrochlore and zirconolite phases. 

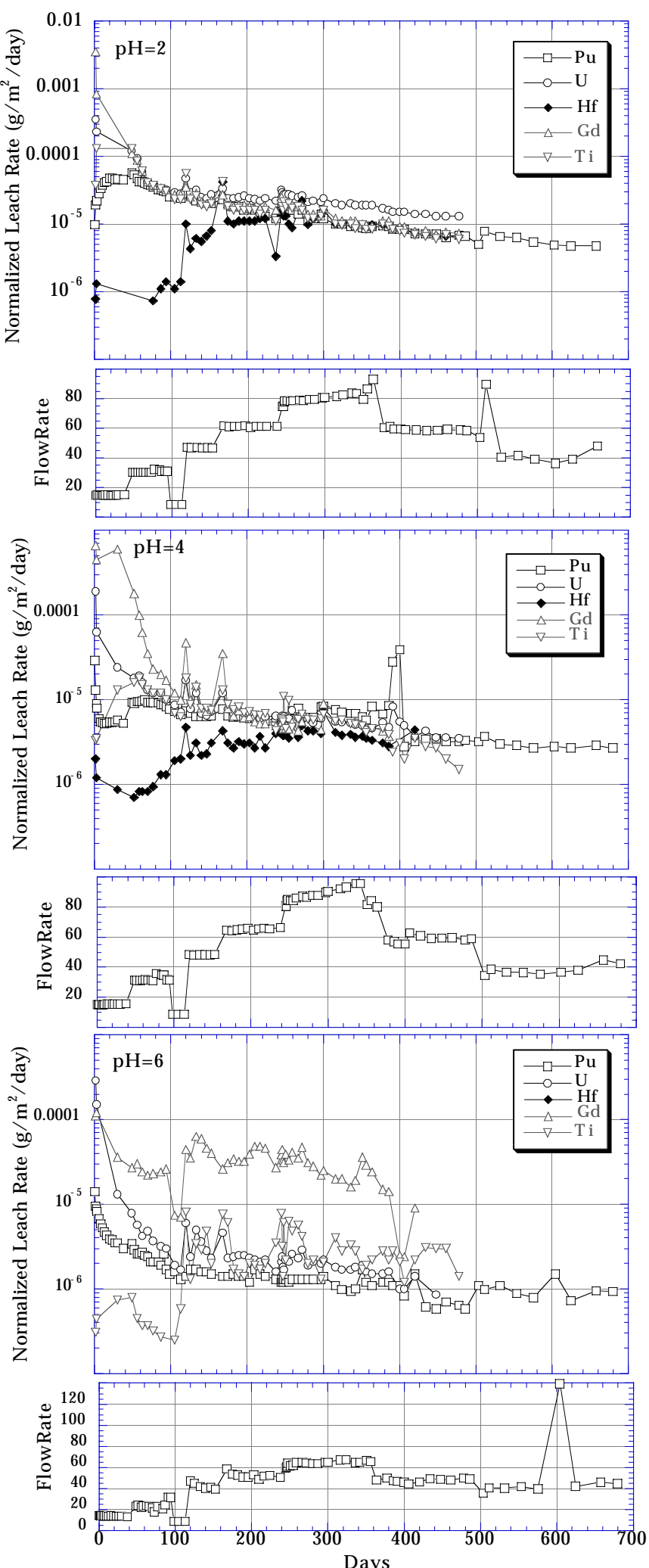

Figure 2. SPFT test results showing normalized leach rates in units of $\mathrm{g} / \mathrm{m}^{2} /$ day for a $\mathrm{Pu}-\mathrm{U}$ pyrochlore-based ceramic at $\mathrm{pH} 2,4$, and 6 , (a-c), All tests were performed at $25^{\circ} \mathrm{C}$. 


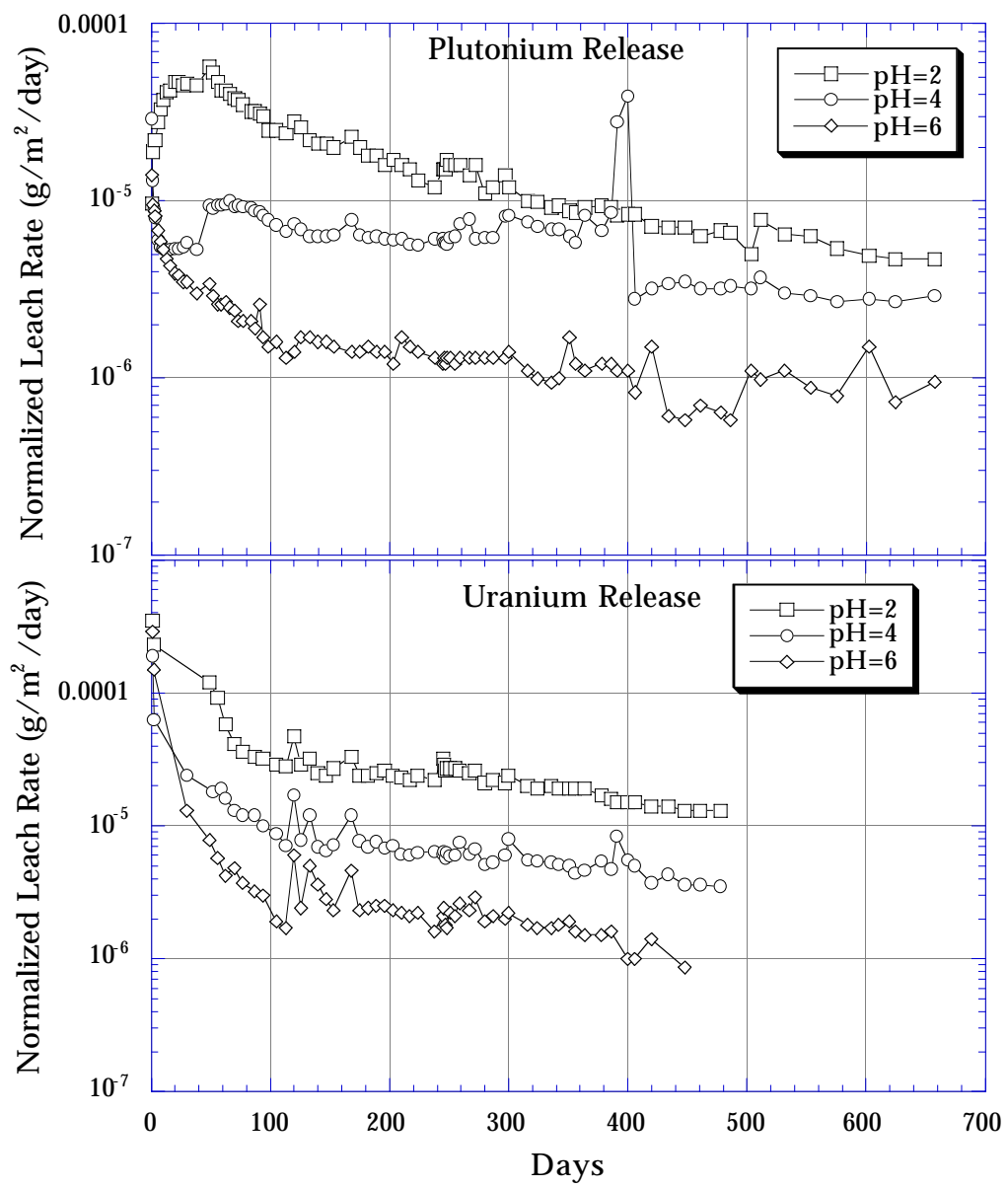

Figure 3. Comparison of normalized release rates for $\mathrm{Pu}$ and $\mathrm{U}$ from ceramic $\mathrm{B}(\mathrm{Pu}-\mathrm{U}$ multiphase ceramic) at $\mathrm{pH} \mathrm{2,} \mathrm{4,} \mathrm{and} 6$.

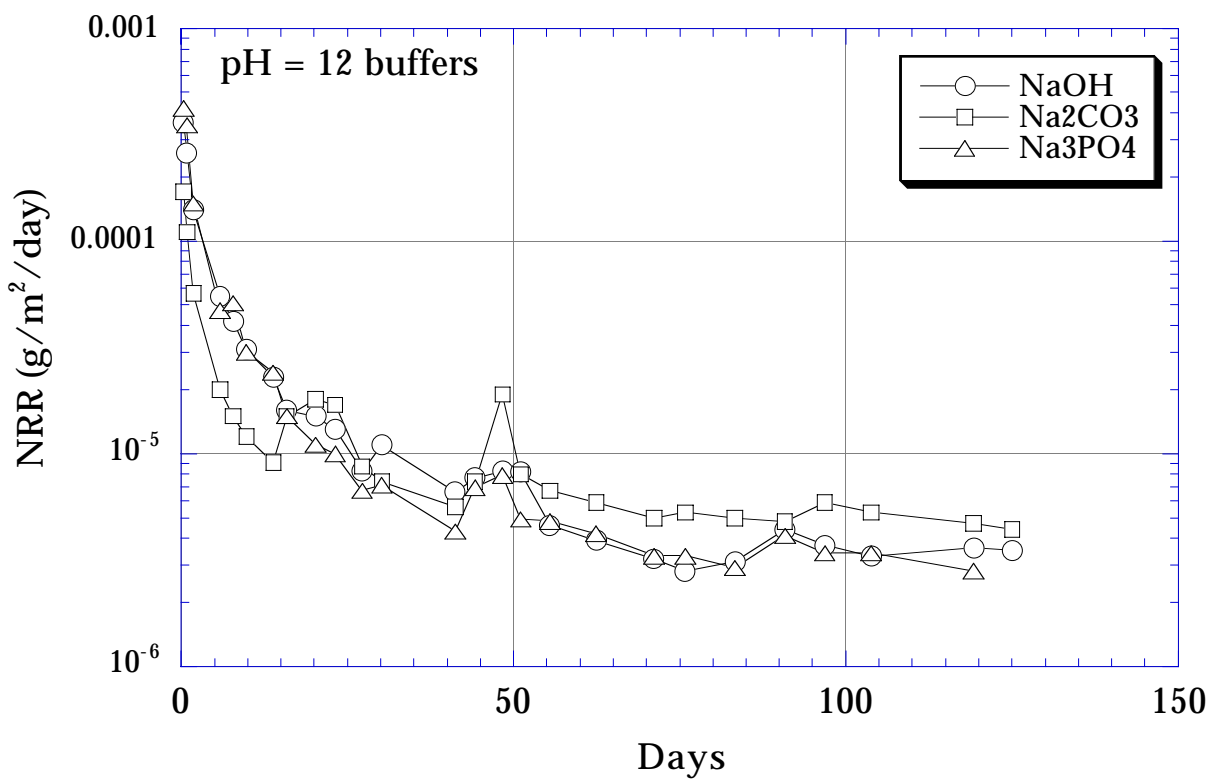

Figure 4. Comparison of SPFT test results for $3 \mathrm{pH} 12$ buffers; $\mathrm{NaOH}$, $\mathrm{Na}_{2} \mathrm{CO}_{3}$ and $\mathrm{KH}_{2} \mathrm{PO} 4$ solutions. Buffer compositions given in Table A2. 

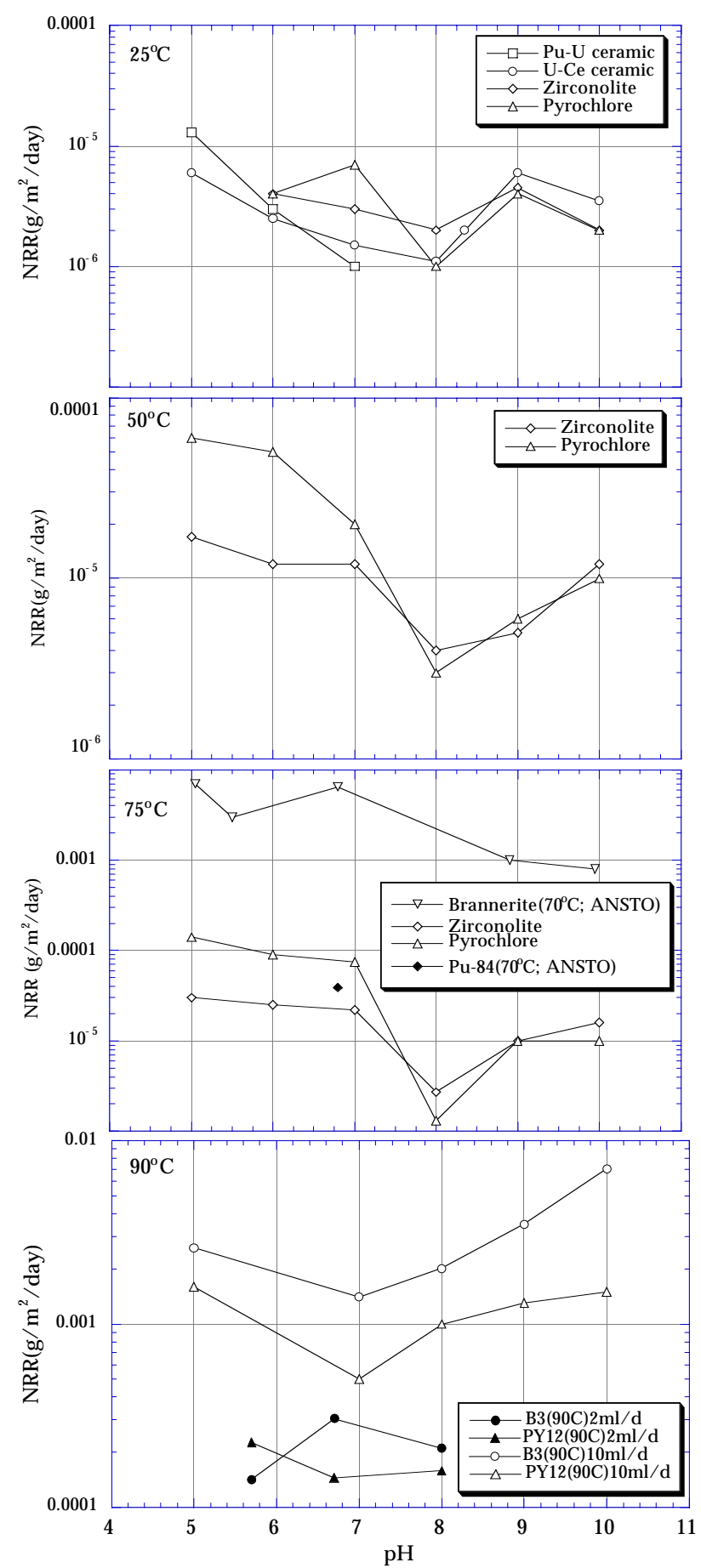

Figure 5. SPFT test results for single-phase pyrochlore and brannerite at 25,50 , and $75^{\circ} \mathrm{C}$ in $\mathrm{pH} 2-12$ buffer solutions. Also shown are the data for the pyrochlore-based $\mathrm{Ce}-\mathrm{U}$ and $\mathrm{Pu}-\mathrm{U}$ ceramics tested at $25^{\circ} \mathrm{C}$, data at $70^{\circ} \mathrm{C}$ for brannerite and a pyrochlore-based ceramic, and data at $90^{\circ} \mathrm{C}$ for two multi-phase ceramics at two different flow rates given in the legend. Data from Appendix 1 and Hart et al., 1999a. 
Single-phase brannerite appears to be significantly less durable than either zirconolite or pyrochlore based on the $70^{\circ} \mathrm{C}$ SPFT data shown in Fig. 5c (Hart et al., 1999a). This is consistent with the MCC-1 test results of brannerite-rich multiphase ceramics (Bakel et al., 1999 b) which show increased release rates of $U$ release relative to brannerite-poor ceramics. We have further tests in progress at other temperatures to confirm this trend. If this is confirmed, it may imply the need to impose more stringent controls on the quantity of brannerite acceptable in the ceramic product.

Figure 6 shows the rate data for single-phase pyrochlore with calculated error bars that represent the standard deviation of the concentration values measured over the duration of the test. This error is much greater than analytical error of the ICP or $\mathrm{pH}$ measurements, which were therefore not included in these error estimates. By including the early data in the calculated error estimates, we obtain a conservative estimate of both the error and the value of the release rate. Because the proper method with which to evaluate error depends on what model we use to interpret the results, we have chosen to use this simple conservative approach to estimate error at this time. The error for the $25^{\circ} \mathrm{C}$ tests is substantial, due mainly to the low dissolution rates and low concentration levels. Estimated uncertainties for the higher temperature data are much smaller and suggest the $\mathrm{pH}$ and temperature trends shown are real.

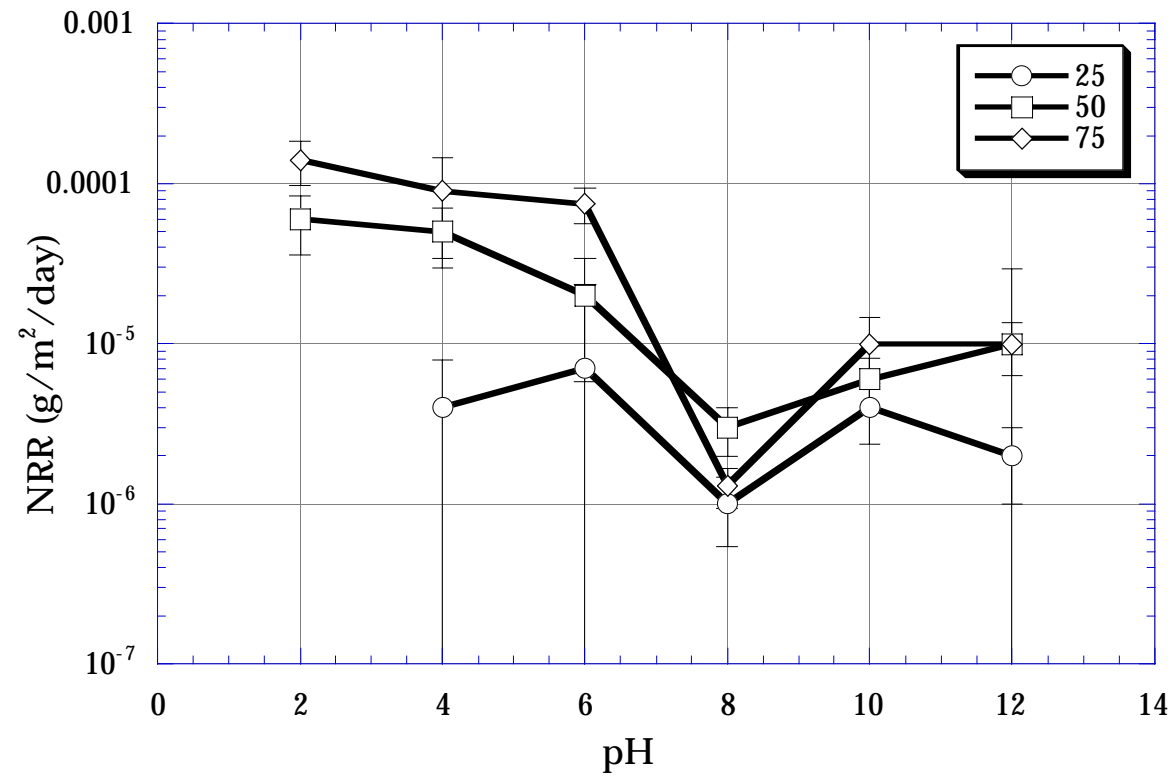

Figure 6. Dissolution rates for single phase pyrochlore at 25,50 , and $75^{\circ} \mathrm{C}$ with error bars showing the calculated standard deviation of data collected over 120 days.

If the ceramic forms a Ti-rich surface layer during dissolution, it might be expected that the measured titanium concentrations would approach the solubility of some Ti-containing phase as the reaction proceeds. Figure 7 shows measured titanium values in solution compared with calculated rutile $\left(\mathrm{TiO}_{2}\right)$ solubilities based on the data of Knauss et al., (1999). The range of data points at each $\mathrm{pH}$ corresponds to the measured values of Ti over time. In general, the values start high and get progressively lower, as can be seen in Figures 1 and 2. Note that the solubility of anatase, a less stable polymorph of $\mathrm{TiO}_{2}$, but one that commonly forms at low temperatures instead of rutile, is about one log unit higher. The 
data suggest possible solubility control at some $\mathrm{pH}$ values and that the saturating phase more closely resembles rutile than anatase, but the data are not conclusive.

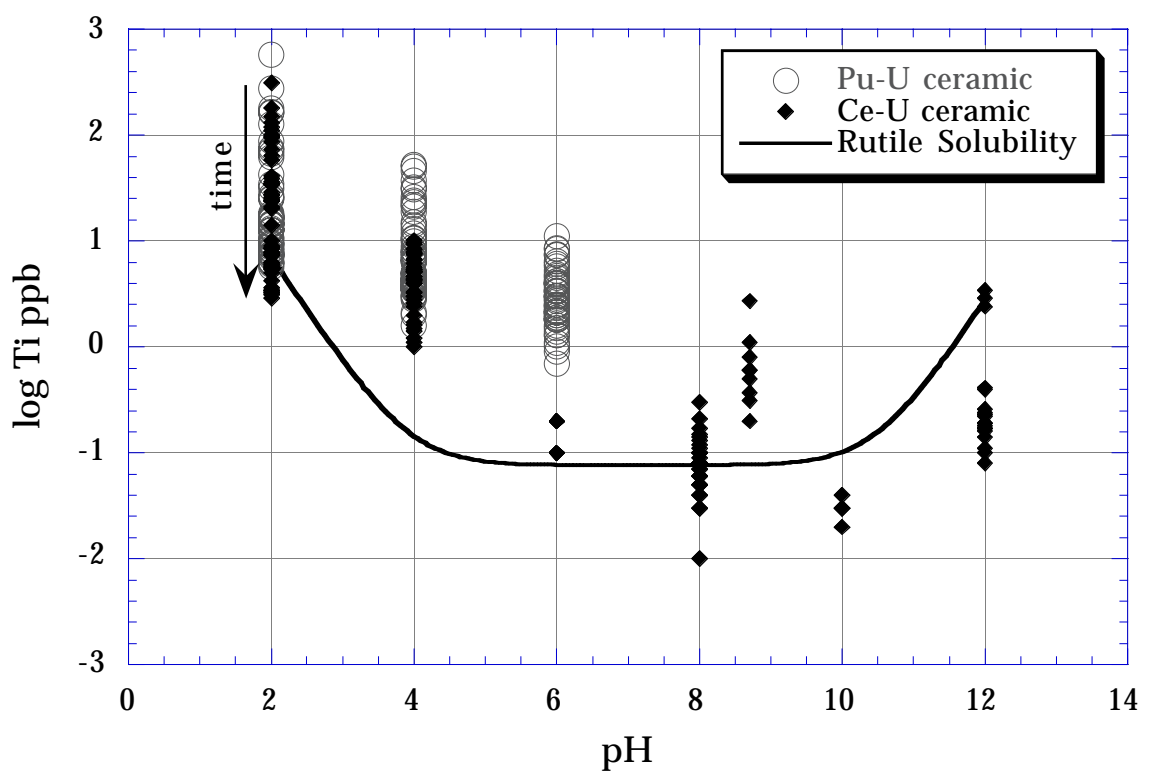

Figure 7. Titanium analyses for $25^{\circ} \mathrm{C}$ SPFT tests compared the solubility curve for rutile $\left(\mathrm{TiO}_{2}\right)$ Data for the $\mathrm{Pu}-\mathrm{U}$ ceramic are in red, data for the $\mathrm{Ce}-\mathrm{U}$ ceramic are in black. The solubility curve for anatase (a less stable $\mathrm{TiO}_{2}$ polymorph), would be about one log unit higher.

\section{$\underline{\text { Surface Area Measurements }}$}

In order to compare the surface areas of ceramics used in our tests to the surface areas to be used in performance assessment calculations, we need some method to relate gas adsorption surface areas (BET) to other types of surface area estimates, such as simple geometric calculations. In Table 3 we compare our $\mathrm{N}_{2}$ BET values with values calculated assuming smooth spherical particles of radius 32 microns, which results in a "geometric" surface area estimate. To calculate the geometric surface area, we assumed that all the particles are spheres that have a diameter equal to the average of the two mesh sizes used to sieve the powder. Other assumptions are possible. Our measured BET values, which take into account surface roughness, are higher than the geometric values by a factor of between about 3 and 10. A similar factor should be used to correct our BET surface areas to a related surface area calculated using some geometric assumption.

Table 3. Surface areas of ceramics in $\mathrm{m}^{2} / \mathrm{g}$.

\begin{tabular}{|llll|}
\hline Ceramic & A $($ Ce-U) & C Pyrochlore & D Zirconolite \\
BET $\left(\mathrm{cm}^{2} / \mathrm{g}\right)$ & 976 & 3461 & 2346 \\
Geometric & 375 & 347 & 347 \\
BET/Geom. & 2.6 & 10 & 6.8 \\
\hline
\end{tabular}

\section{Alteration Layers and Precipitates}


Because of the slow reaction rates of the ceramics with aqueous fluids, characterization of the alteration layers and secondary phases has been difficult. For example, the thickness of the surface alteration layer for a SPFT test can be estimated based on the differences in release rates of elements. Table 4 shows such a calculated layer thickness for one year $25^{\circ} \mathrm{C}$ tests of a pyrochlore-based ceramic (Ceramic A in Table 2). The calculation makes the simple assumption that uranium is completely removed from a surface layer to some depth, and uses the cumulative amount of uranium released to calculate that depth. The residual alteration layer is presumably composed of more slowly released elements such as $\mathrm{Hf}$ and $\mathrm{Ti}$, which are often below detection limits in solution. As can be seen, the estimated thickness are very small, ranging from 0.2 to $4 \mathrm{~nm}$ (2-40 Angstroms) for a one year test duration at $\mathrm{pH}$ values as low as 2 . Although layers of this thickness might seem to be too thin to provide a barrier to continued dissolution, oxide layers of this thickness are responsible for the passivation of metal surfaces and the consequent corrosion resistance of substances such as Ti metal and stainless steel (Magnussen and Behm, 1999; Ryan et al., 1999). It is therefore plausible that they may be responsible for the time dependence of corrosion behavior of the titanate ceramics reported here.

Attempts to characterize this alteration layer on samples reacted at temperatures up to $250^{\circ} \mathrm{C}$ (to enhance layer formation) using surface-sensitive electron-yield-mode x-ray absorption spectroscopy have failed to detect a difference in surface layer composition between reacted and unreacted samples (P. Allen, pers. com.). The sensitivity of this technique is believed to be 200-400 Angstroms. This work suggests that the layers, if they exist, are very thin and have thicknesses consistent with our estimates based on the release rate data.

Table 4. Calculated leached layer thicknesses after one year of reaction.

\begin{tabular}{|lccccccc|}
\hline $\mathbf{p H}=$ & $\mathbf{2}$ & $\mathbf{4}$ & $\mathbf{6}$ & $\mathbf{8}$ & $\mathbf{8 . 7}$ & $\mathbf{1 0}$ & $\mathbf{1 2}$ \\
Thickness $(\mathbf{n m})$ & 4 & 1.3 & 0.7 & 0.2 & 0.3 & 0.2 & 0.3 \\
\hline
\end{tabular}

Fig. 8 shows before and after SEM images of ceramic grains that have been reacted for one year in $\mathrm{pH} 2$ solutions. Again, we see little evidence of reaction. Most crystalline and glassy silicate solids reacted under similar conditions would show rounded edges and smooth surfaces, with small-sized grains dissolved away. At the resolution of these SEM 

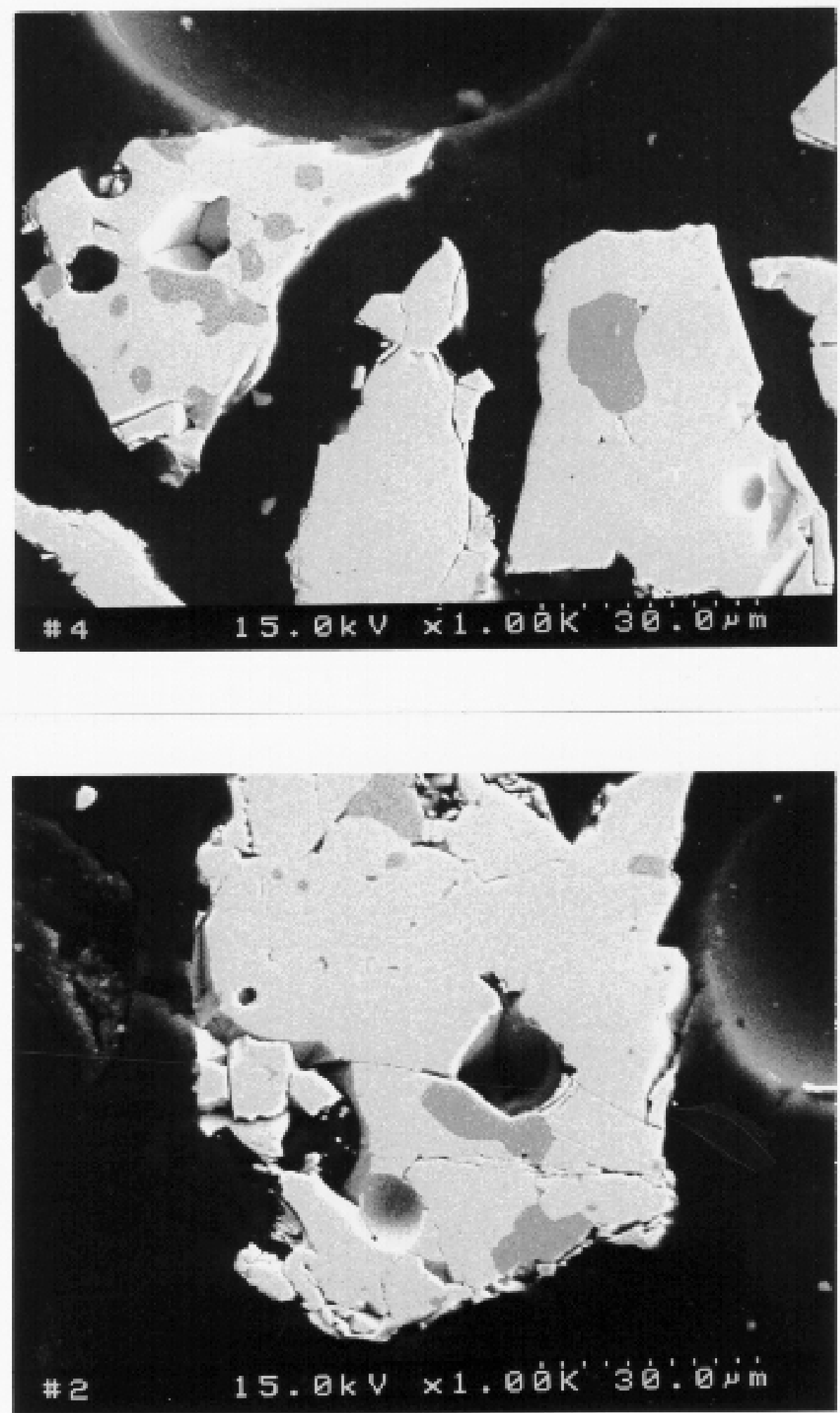

Figure 8. Unreacted (a) and reacted (b) samples of Ce-U ceramic. (sample A of Table 2). Reacted sample was leached in $\mathrm{pH} 2$ buffer solution in SPFT tests for one year. The reacted sample appears identical to the unreacted, with no obvious rounding or smoothing of edges and pits. 
images (note 30-micron scale bar), alteration layers of tens to hundreds of Angstroms would not be observable.

Static tests are expected to generate larger and better-developed secondary phases than flow-through tests because the ceramic remains in contact with the solution, which can therefore reach saturation with respect to secondary phases. Therefore, more effort has been made to characterize secondary minerals that form in these types of tests.

Unfortunately, because of the slow reaction rates, few data that can be used to characterize the reaction products have been obtained. In long-term static tests of the early zirconolite ceramic (Bakel et al., 1999a), rutile was tentatively identified as an alteration product. In high temperature $\left(200^{\circ} \mathrm{C}\right)$ vapor hydration tests (VHT) (Bakel et al., 1999a), small amounts of phosphates and iron oxides were found. Neither iron nor phosphate were intended to be constituents of the ceramic and must have been present as impurities. Also observed in the VHT were Ti-rich rinds in contact with zirconolite (Fig. 9). A similar Tienriched alteration layer was observed on brannerites reacted at $70^{\circ} \mathrm{C}$ in SPFT tests (Hart et al., 1999b). Natural analog studies of brannerite from several locations have identified anatase, rutile, and an $\mathrm{Al}+\mathrm{Si}+\mathrm{P}$-enriched Ti-oxide phase (Hart et al., 1999b).

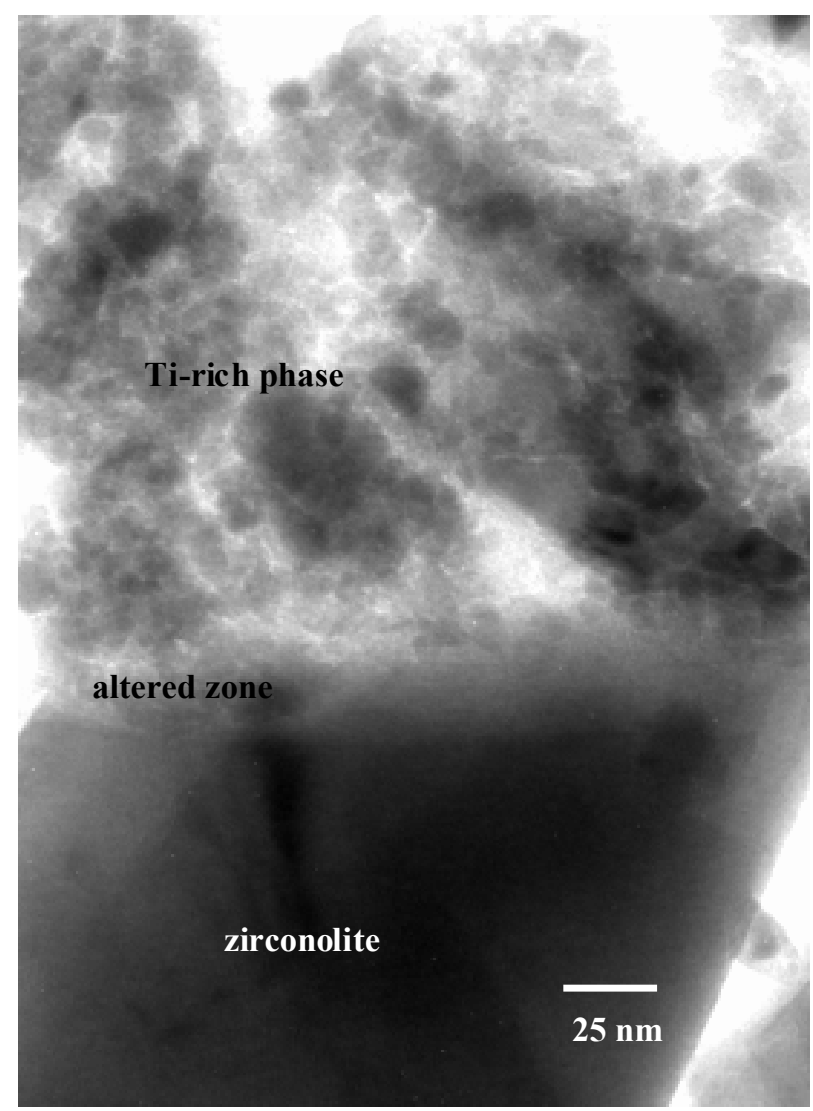

Figure 9. Ti-enriched reacted layer on a corroded zirconolite surface (Bakel et al., 1999a) from $200^{\circ} \mathrm{C}$ vapor hydration test of an early zirconolite-based ceramic formulation. 


\section{Effects of impurities}

Static tests conducted to compare the baseline formulation with the same formulation doped with impurities have revealed no significant differences in durability. This is confirmed by MCC-1 testing of a baseline ceramic with added $8 \mathrm{wt} \%$ impurities (Bakel et al., 1999c). The impurities consist of $\mathrm{Al}, \mathrm{Cr}, \mathrm{Fe}, \mathrm{Ni}, \mathrm{Zn}, \mathrm{Cu}, \mathrm{F}, \mathrm{Mg}, \mathrm{Mo}, \mathrm{Na}, \mathrm{P}, \mathrm{Pb}$, and $\mathrm{Si}$. No difference in durability between the pure and impure ceramic was found. Similar tests of impure ceramics containing additional $\mathrm{Ni}, \mathrm{Nd}, \mathrm{Zn}, \mathrm{La}, \mathrm{Si}, \mathrm{Na}, \mathrm{Mg}, \mathrm{Fe}, \mathrm{Al}, \mathrm{Cr}, \mathrm{K}$, Mo, Ta, W, Sn, Ba, and P also show no measurable difference in dissolution rates (Hart et al., 1999a). These data suggest that at these levels of impurities, the added elements either: (1) fit into existing lattice sites in the major phases of the ceramic without significant destabilization; (2) form a separate, relatively durable phase that dissolves no faster than the titanate matrix; or (3) form a relatively non-durable phase that does not contain any of the actinides or neutron absorbers. Phase identification and characterization work suggests that both the first and last explanations explains the test data in most cases (Bakel, 1999b).

\section{Effects of radiation damage}

A previous study, which summarizes work on the effects of radiation damage on mineral corrosion, recommends that a factor of between 10 and 30 be used to correct dissolution rates of undamaged minerals to their radiation-damaged equivalents (Van Konynenburg, 1997). This number is based on a small quantity of short-term laboratory data and some information from field investigations of natural pyrochlores and zirconolites. Recent durability data on rare earth element pyrochlores (Y, Gd and $\mathrm{Lu}$ ) that have been irradiated with heavy ions show that in SPFT tests at $90^{\circ} \mathrm{C}$ the ceramics dissolved up a factor of 5 times faster than the unirradiated ceramics (McGrail et al., 1999) Attempts to use MCC-1 tests to measure a difference in dissolution rates between ion-irradiated and unirradiated samples of the ceramic intended for Pu immobilization were (Crawford et al. 1999). The dissolution rates of both materials were below detection limits, which were limited by the background concentrations of the elements of interest. All that can be said from these tests is that there does not appear to be a large increase in corrosion rate of the ceramic due to the effects of radiation damage. Our previous input for repository performance assessments recommend a value of 30 times to account for the possible increase in reaction rate of the radiation-damaged ceramic versus the non-irradiated. This value appears to be conservative and should continue to be used. Work is in progress using ${ }^{238} \mathrm{Pu}$-containing ceramics to better determine the effects of radiation damage.

\section{Effects of other repository materials}

Some experimental data are available from tests designed to determine the effects of other repository materials on ceramic performance. Vapor hydration tests conducted for 28-56 days on small disks of ceramic sandwiched between two disks of glass showed no effect of the glass on ceramic behavior (Mertz et al., 1999). Although the glass added significant amounts of dissolved species to the thin surface film of adsorbed water, and raised the $\mathrm{pH}$ of the film, the ceramic appeared to be unaffected.

Results from pressurized unsaturated flow (PUF) tests of DHLW glass with the older zirconolite-based ceramic may show some evidence of an enhanced dissolution rate of the ceramic due to interaction with the glass (Mc Grail et al., 1999). Barium release rates 
appear to correlate with $\mathrm{pH}$ excursions related to precipitation of alteration phases on the glass. (Barium was only present in the ceramic in these tests.) However, this interpretation is preliminary and the implied increase in dissolution rate as a function of $\mathrm{pH}$ does not agree with relatively small $\mathrm{pH}$ dependence found in SPFT tests. Other mechanisms, such as a coupled hydrologic and chemical process involving periodic flow through restricted pore spaces may better explain the data.

\section{Dissolution mechanism}

In order to make reliable long-term extrapolations of dissolution rates over repository time frames, it is of key importance to determine the underlying rate-controlling mechanism for waste form dissolution. Short-term trends measured in the laboratory cannot be extrapolated reliably unless the correct mechanistic model is used as the basis of extrapolation. Most experimental dissolution rate data sets are too noisy to allow extraction of long-term trends using a purely statistical methodology. Any change in rate, such as a continual decrease due to surface layer buildup, or increase in rate due to precipitation of alteration minerals and consequent change in reaction affinity, will never be correctly predicted by a purely statistical approach. For this reason, it is important to try to develop a fundamental understanding of the dissolution process(es) from our experiments.

The dissolution mechanism for oxides dissolving in water is believed to be rate-limited either by the rate of breakage of network bonds (surface reaction control), or the rate of transport of species through either a surface leached layer or through the aqueous solution. For the titanate ceramic, surface reaction control would imply that the rate of hydrolysis of the Ti-O structural bond determines the dissolution rate. Transport control would imply that it is transport (diffusion) of elements such as $U$ through a surface alteration layer that controls the rate of $U$ release. Characteristic changes in the dissolution rate as a function of certain environmental parameters can be used to differentiate between these rate-limiting mechanisms.

\section{Temperature Effects}

The effect of temperature on a reaction that is rate controlled by some mechanism generally follows an Arrhenius relationship characterized by a linear dependence of the log of the rate with reciprocal temperature. If the rate-limiting mechanism changes, there will be a break in slope at the transition temperature between the two mechanisms. Arrhenius plots are useful for determining whether it is valid to extrapolate a reaction rate measured at one temperature in the laboratory to some other temperature. In addition, the magnitude of the activation energy, given by the slope of the $\log ($ rate $) v s .1 /$ T plot, can also be indicative of the rate-limiting mechanism. Activation energies for transport through aqueous solutions

are about $5 \mathrm{kcal} / \mathrm{mole}$. Dissolution reactions having this rate dependence on temperature are likely to be controlled by this mechanism. Activation energies of $15-25 \mathrm{kcal} / \mathrm{mole}$ are characteristic of surface reaction control (i.e., hydrolysis of network-forming bonds in an oxide structure), although there are exceptions (see (Lasaga, 1998, Table 1.3). Activation energies for diffusion though crystalline solids can be much higher. Although knowledge of the activation energy does not uniquely identify the rate control, it helps select between various types of control, and it is also necessary for extrapolating rate data to other temperatures. 
Figure 10 is an Arrhenius plot for the titanate ceramic, based on averaged SPFT data at temperatures of $25,50,75$, and $90^{\circ} \mathrm{C}$. (Note that the data includes results for both singlephase and multi-phase ceramics. It would be best to plot only data for a single phase were it available). The slope can be used to derive an apparent activation energy for the dissolution reaction of about $16 \mathrm{kcal} / \mathrm{mole}$. Better data, as a function of $\mathrm{pH}$, would allow us to evaluate the activation energy as a function of $\mathrm{pH}$; however, this cannot be done given the uncertainties in the existing data. Silicate minerals are known to have different activation energies for dissolution at different $\mathrm{pH}$ values (Lasaga, 1998), and by implication, different rate-limiting reaction mechanisms.

\section{Release Rate Behavior over Time}

In flow-through tests, surface-reaction-controlled minerals should show constant dissolution rates with time (when corrected for decreasing surface area as the mineral grains shrink during dissolution), whereas minerals rate-limited by diffusion through a thickening leached layer should show rates that continually decline as a transport-limiting leached layer thickens with time. Eventually, the transport-limited rate would also become constant when the rate of dissolution of the outer layer of leached material equals the rate of leached material formation, and steady-state conditions are achieved. Our data show qualitative agreement with a diffusion control, in that the dissolution rates continue to decrease even after two years of testing.

We can better evaluate diffusion of ions through a leached layer as a potential rate-limiting mechanism by comparing our dissolution rate measurements over time with model

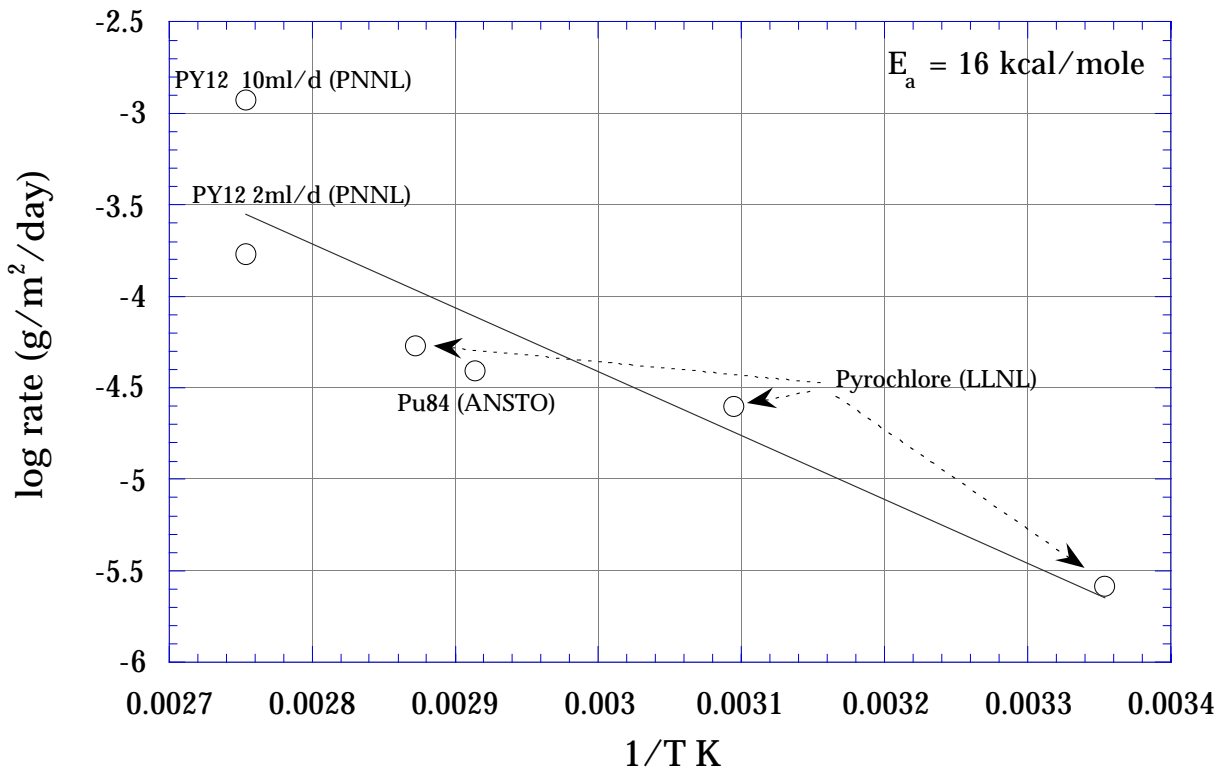

Figure 10. Arrhenius plot of $\log$ reaction rate $v s .1 / \mathrm{T}$ for pyrochlore and pyrochlore-based multi-phase ceramics at temperatures from 25 to $90^{\circ} \mathrm{C}$ based on $\mathrm{U}$ release and averaged values over entire $\mathrm{pH}$ range of tests. The data are best fit by an apparent activation energy for dissolution of $16 \mathrm{kcal} / \mathrm{mole}$ (Data from Appendix 1 of this report, Mc Grail et al., 1999, and Hart et al., 1999a).

predictions based on the equations which describe diffusion. Given a sufficiently thin surface diffusion layer where the radius of the particle is much greater than the thickness of 
the layer (which is the case for our data), our problem reduces to a one-dimensional solution for the conditions shown in Figure 11 and discussed below.

For this problem, we need a solution to Fick's second law:

$$
\frac{\partial C}{\partial t}=D \frac{\partial^{2} C}{\partial x^{2}}
$$

where $\mathrm{C}$ is the concentration of some component of interest (i.e. uranium), $\mathrm{t}$ is time, $\mathrm{D}$ is the diffusion coefficient assumed constant throughout the diffusion layer, and $\mathrm{x}$ is position where $\mathrm{x}=0$ at the ceramic-solution interface. Our solution must satisfy the boundary condition

$\mathrm{C}=0, \mathrm{x}<0, \mathrm{t}>0$

and initial condition

$\mathrm{C}=\mathrm{C}_{0}, \mathrm{x}>0, \mathrm{t}=0$.

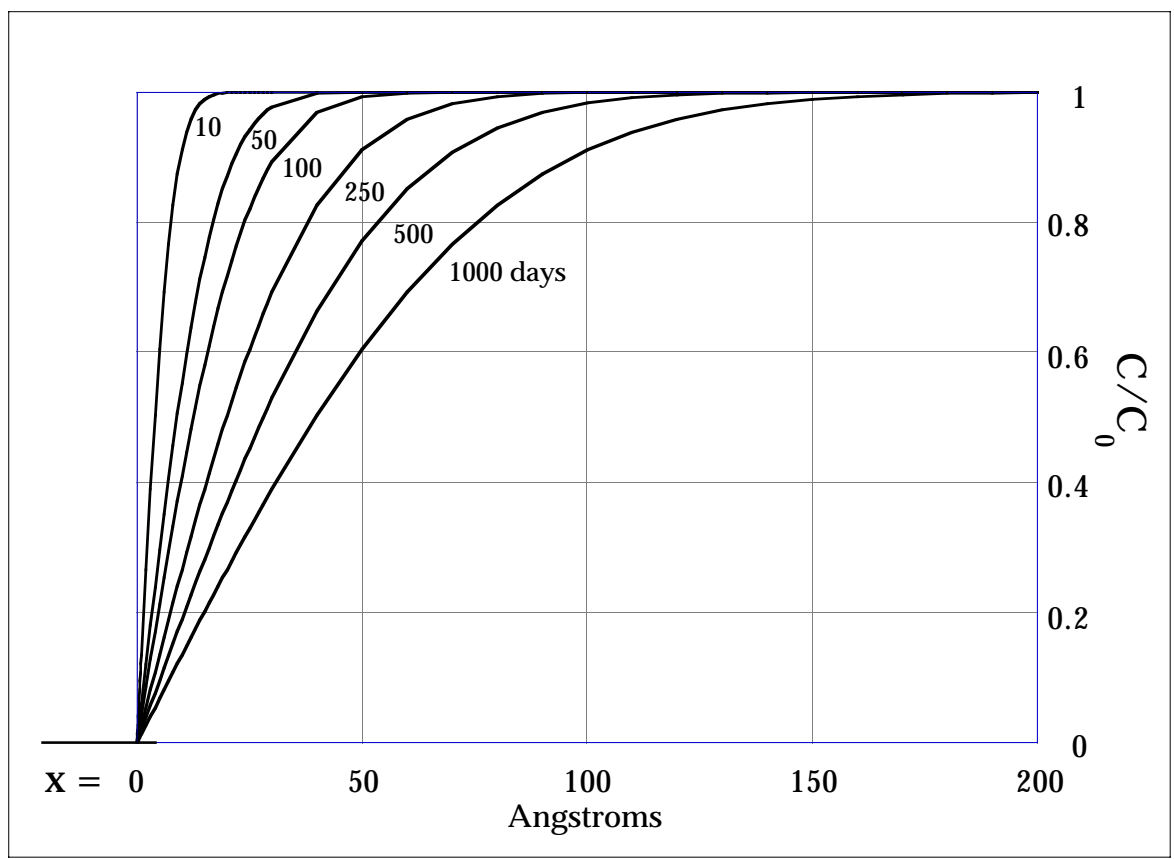

Figure11. Schematic of initial and boundary conditions for diffusion problem used to model uranium release rate data for SPFT tests. Boundary condition imposed is that elemental concentrations are zero at leached layer-solution interface $(x=0)$ at all times. Ceramic is treated as infinite slab of constant uranium concentration $\left(\mathrm{C}_{0}\right)$. Also shown are six calculated profiles for reaction times of 10 to 1000 days for uranium in $\mathrm{Ce}-\mathrm{U}$ ceramic at $\mathrm{pH} 2$ using the diffusion constant given in Figure 12.

The solution is (page 21, Eqn. 2.45 in Crank, 1975): 
$C=C_{0} \operatorname{erfc} \frac{x}{2 \sqrt{D t}}$

The flux of a component into solution is obtained using this solution (3) and Fick's first law:

$J=-D_{i} \frac{\partial c_{i}}{\partial x}$

where $\mathrm{J}$ is the flux of some component through the diffusion layer with concentration gradient $\mathrm{dc}_{\mathrm{i}} / \mathrm{dx}$ and diffusion coefficient $\mathrm{D}$. At the solution-boundary interface the flux of some component into solution is simply the concentration gradient times the diffusion coefficient. The concentration gradient is given by the derivative of (3) evaluated at $x=0$ :

$$
\frac{\partial C}{\partial x}=\frac{C_{0}}{\sqrt{\pi D t}} \bullet \exp \left(\frac{-x^{2}}{4 D t}\right)
$$

which, at $\mathrm{x}=0$, the solution-solid interface, reduces to:

$$
\frac{\partial C}{\partial x_{x=0}}=\frac{C_{0}}{\sqrt{\pi D t}}
$$

so that the flux at the boundary is:

$$
J=C_{0} \sqrt{\frac{D}{\pi}} \cdot \frac{1}{\sqrt{t}}
$$

where $\mathrm{J}$ is the experimentally determined dissolution rate in $\mathrm{g} / \mathrm{m}^{2} /$ day given in Eqn. 1 . It follows from Eqn. 7 that if the release rate is diffusion controlled, a plot of $\mathrm{p}\left(\mathrm{J} / \mathrm{C}_{0}\right)^{2} \mathrm{vs}$. $1 /$ time should lie along a straight line which has a slope equal to the diffusion coefficient. Such plots of our release rate data for $25^{\circ} \mathrm{C}$ tests of the baseline ceramic (same data as shown in Figure 1) for uranium are shown in Figure 12. Uranium data were used because they are believed to have the smallest analytical error and smallest amount of background contamination. Uranium is the only element that was detected in all the experiments at all $\mathrm{pH}$ values. The plots show reasonably good fits to the diffusion model for the best data sets, especially at low $\mathrm{pH}$ values. The data at $\mathrm{pH} 8$ and 10 have a very large experimental error and therefore are not useful for testing rate models.

The values of the diffusion coefficients are shown in Figure. 12 as the linear regression parameter ' $\mathrm{D}$ ' in units of $\mathrm{cm}^{2} / \mathrm{sec}$ (i.e. at $\mathrm{pH} 2, \mathrm{D}=8 \times 10^{-22} \mathrm{~cm}^{2} / \mathrm{sec}$ ) They vary with $\mathrm{pH}$ and range in value from $10^{-21}$ to $10^{-23} \mathrm{~cm}^{2} / \mathrm{sec}$ (excluding the $\mathrm{pH}=8$ data set which had the largest uncertainties and erratic trend with time). These values are much higher than would be expected for bulk diffusion coefficients based on extrapolation to room temperature of high temperature data for oxides and silicates (Lasaga, 1998, Freer, 1980) where values are commonly 10-30 log units lower than what we derive here. Our measured values are in better agreement with grain boundary diffusion rates which can be 
$10 \log$ units higher than bulk diffusion rates. It may be that if a surface layer is limiting dissolution rates, it is composed of a microcrystalline, defect-ridden and hydrated material, which would be expected to have a diffusion coefficient in better agreement with our calculated values.

This analysis of the release rate data assumes several simplifications:

- the diffusion coefficient is constant throughout the leached layer.

- the rate of dissolution of the leached layer at the solution-solid interface is zero

- no account is taken for fast-dissolving fines and disturbed surface material at early times

Fine particles and disturbed material would dissolve faster than bulk ceramic early at early times, and experimental data which reflects this higher rate would tend to plot above the diffusion lines in Figure 12. Furthermore, if the leached layer is dissolving at some finite rate, rather than not dissolving at all as we assume in the model, dissolution rates would tend to level off and reach a steady-state rate higher than what is predicted by the simple diffusion model. Therefore, qualitatively, a combination of these two factors suggests that the experimental data should follow a concave upward curved trend relative to the diffusion model line. Such trends can be seen in plots for $\mathrm{pH}$ 2, 6, 8.7, and 12.

In Figure 11 we also plot the calculated thickness of the leached layer for the Ce-U ceramic at $\mathrm{pH} 2$ using our regressed diffusion constant. Lines are drawn for times of 10 to 1000 days. Note the calculated leached layer thicknesses are very thin, less than 200 Angstroms, and consistent with the thicknesses estimated from the release data. This does not confirm the validity of the model, it just demonstrates that it correctly reproduces data used as input.

A more visually-based test of the goodness of the diffusion model is shown in Figure 13 where uranium release rate is plotted vs. time. The line is a regression through the data having the form $\mathrm{A}+\mathrm{B} / \mathrm{t}^{1 / 2}$. The constant term allows some flexibility in the fit to the early time data where there may be contributions from small particles and high surface energy material. The diffusion constant for this regression (derived from the B regression parameter) is consistent with the value determined in Figure 12 for the same data set.

Whether release rates are diffusion controlled or not has important implications for performance assessment. With diffusion control, rates are expected to continually decrease with time as the leached layers thicken. Eventually, when the rate of dissolution of the leached layer itself equals the rate of formation of the layer, a steady state would be achieved in which the release rates become constant. We could therefore justify our use of short-term laboratory data as conservative upper bounds on release rates. Even if the leached layers eventually thicken and spall from the dissolving ceramic, rates would not be expected to ever be higher than the short-term rates. This is unlike the case for surface reaction control, in which changes in solution composition can cause dissolution rates to increase, and our ability to predict these increases depends upon our ability to predict fluid chemistry in the evolving repository.

Better evaluation of diffusion control can be obtained by a more detailed analysis of the hypothetical surface leached layer. Key data would be measurements of the thickness and composition of the layer, as well as elemental profiles through it. 


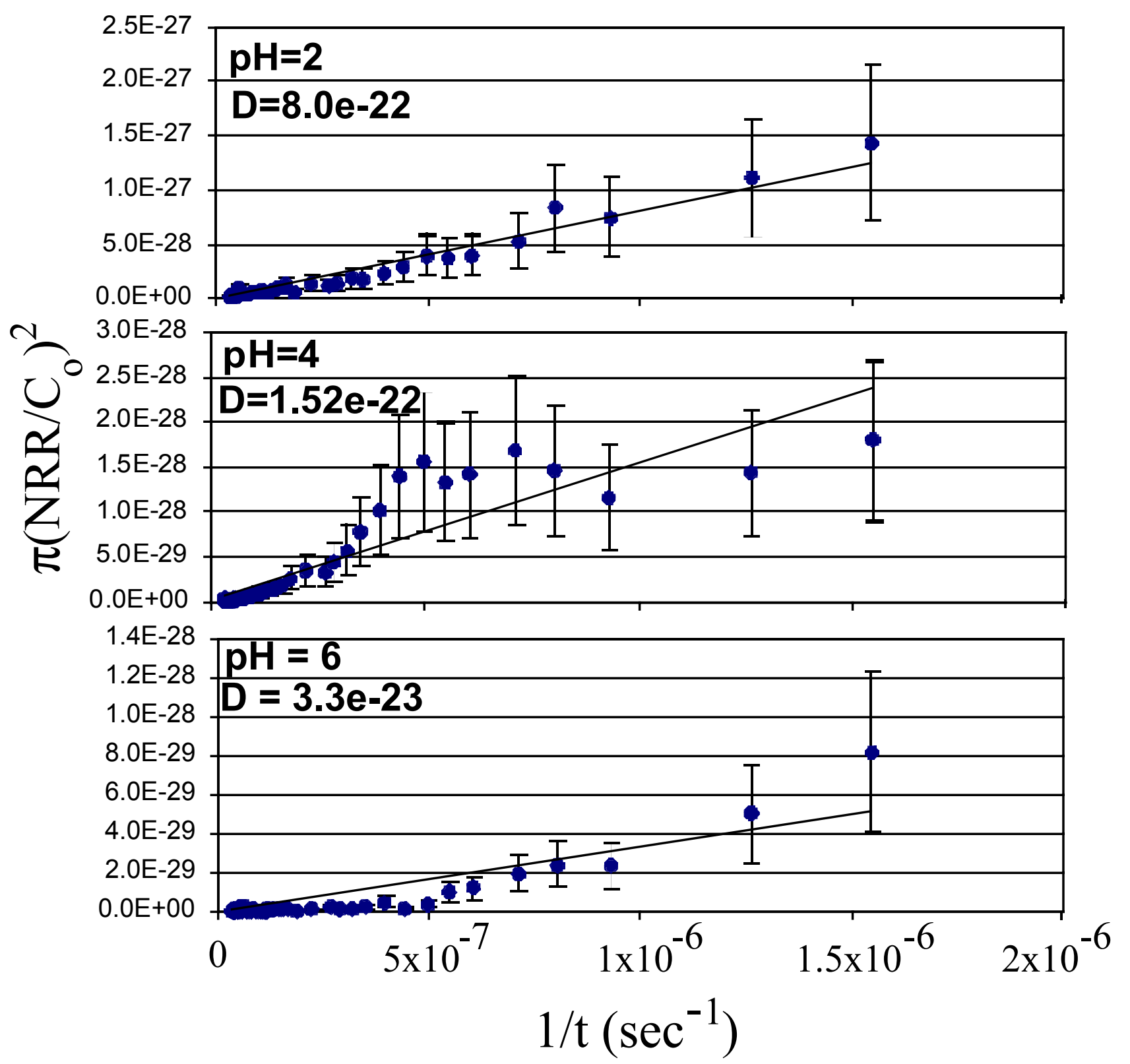

Figure 12. Plots of release rates of $U\left(\left(-\mathrm{J} / \mathrm{C}_{0}\right)^{2}\right)$ vs. $1 /$ time from $25^{\circ} \mathrm{C}$ tests of the $\mathrm{Ce}-\mathrm{U}$ multi-phase ceramic (composition $\mathrm{A}$ in Table 2). The retrieval of diffusion coefficients from the regression assumes no dissolution of the leached layer at the solution boundary and therefore that the layer thickness continues to increase with time. The estimated diffusion coefficient (D) is given for each $\mathrm{pH}$. The uranium concentration in the ceramic used in this calculation is $1.5 \mathrm{~g} / \mathrm{cm}^{3}$. The error bars shown are $50 \%$ of the measured values for all data and are based on average reproducibility for measured uranium concentrations over time. 

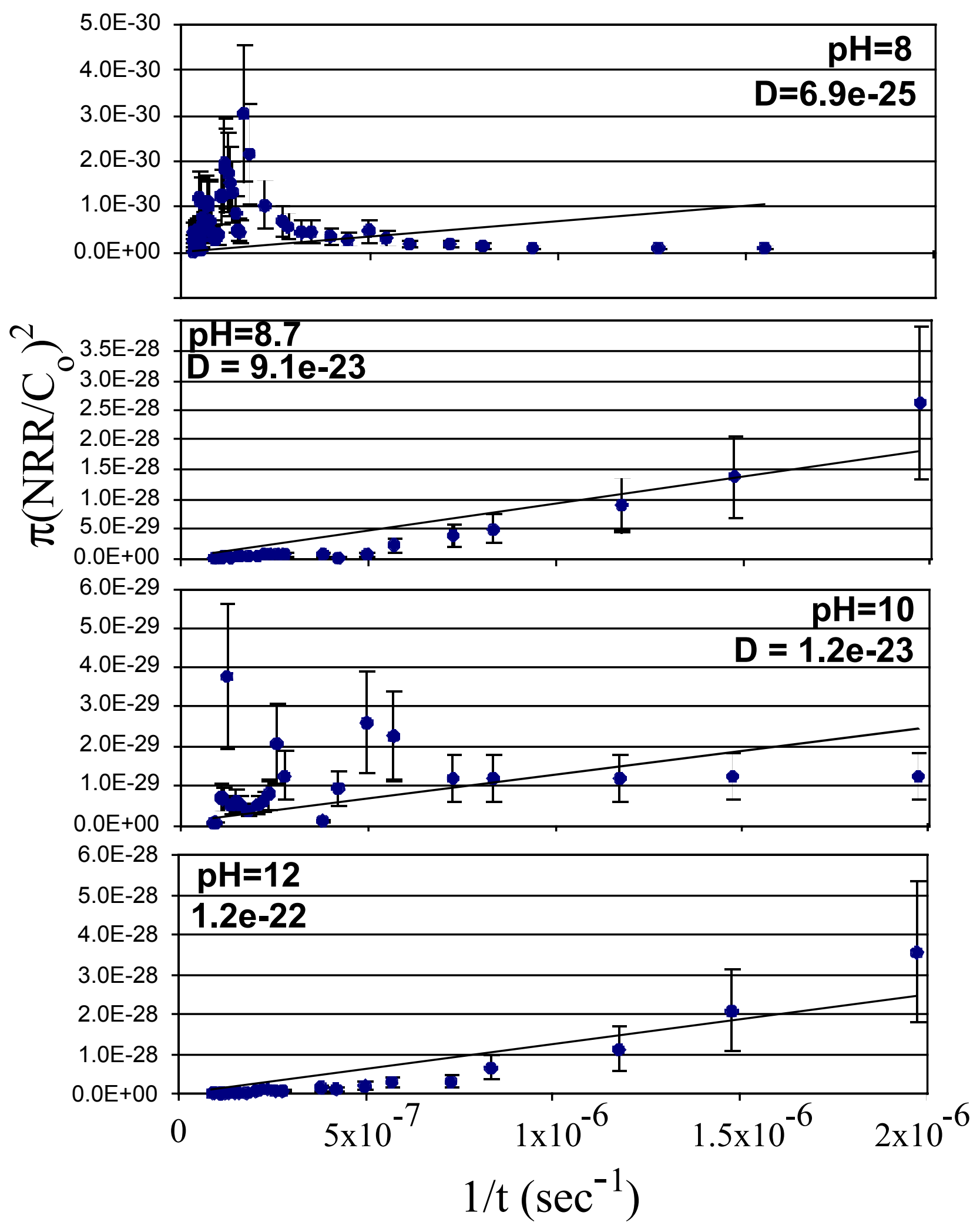

Figure 12. cont. 


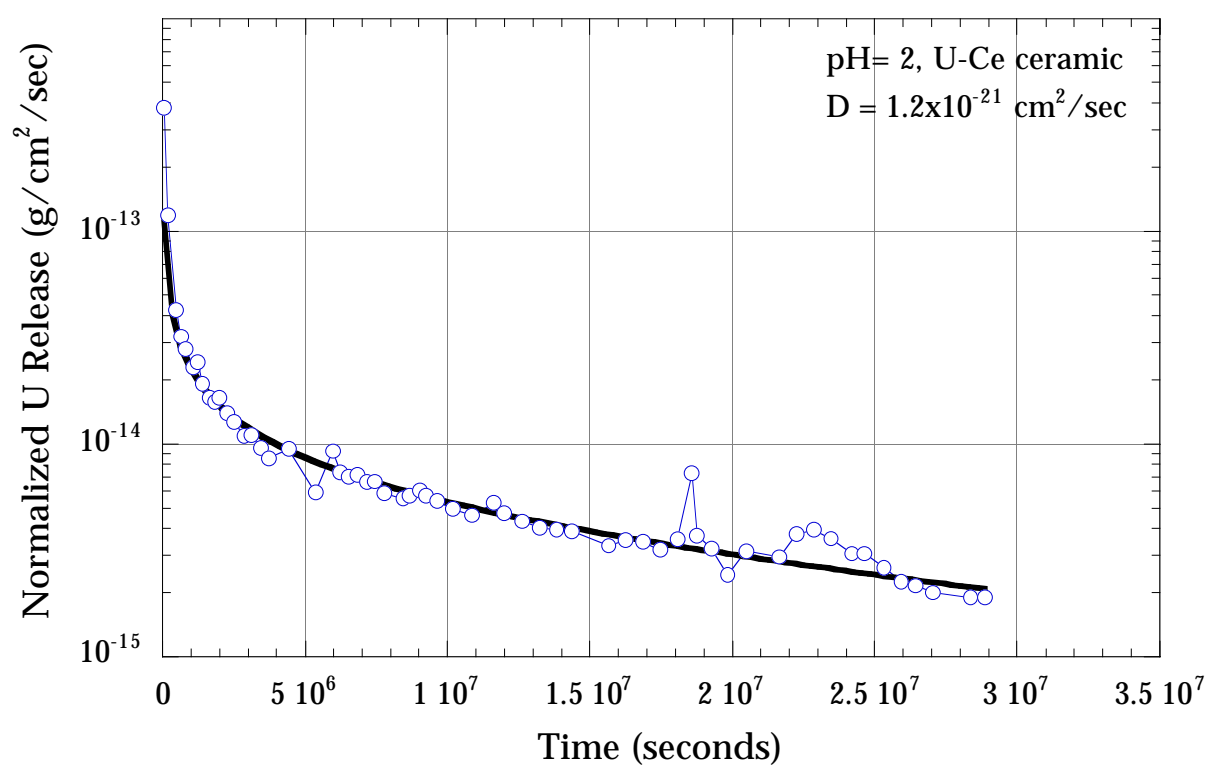

Figure 13. Measured uranium release from the Ce-U ceramic at $\mathrm{pH} 2$ vs. time and a fit to the data of the form $\mathrm{A}+\mathrm{B} / \mathrm{t}^{1 / 2}$.

Alternatively, we know that grinding up our ceramic solids for use in dissolution tests creates high-free-energy material (Hochella, 1990; Velbel, 1986). In addition, there is some quantity of very fine-grained material that is known to dissolve faster than larger grains. Because ceramic dissolution rates are so low, it is possible that our long-term data are simply showing the removal of the fast-dissolving material, and that we have not yet reached the dissolution rate plateau characteristic of the bulk ceramic. Whereas with faster dissolving materials such as borosilicate glasses, we see a decay lasting only a few days, with the titanates, it may last several months to years. The releases we have observed may be dominated by surface energy, defects and fine-grained material, all dissolving at a rate controlled by the hydrolysis rate of the Ti-O bond.

\section{Recommended Parameters for Performance Assessment}

We clearly do not yet adequately understand what controls the rate of dissolution of the titanate waste form. We therefore cannot provide a mechanistically based model for use in performance assessment. For this reason, we have chosen to make some conservative assumptions based on our existing data that should be valid for any of the likely dissolution- rate-limiting mechanisms. We have used our short-term release rate data from SPFT tests (shown in Fig. 14) for temperatures of $25,50,70$, and $75^{\circ} \mathrm{C}$ for both ceramics and single phases. We have excluded brannerite from the data set because of the current small quantity of data for it. We have used an activation energy consistent with the Arrhenius plot in Figure 10 (16 kcal/mole) to fit these data as shown by the dashed lines in Figure 14. Note that the dissolution rates generally show a minimum at neutral to slightly alkaline $\mathrm{pH}$ values. Table 5 provides the equations for the "V"-shaped $\mathrm{pH}$-dependent rates at $25^{\circ} \mathrm{C}$ for use as input into geochemical modeling codes such as EQ3/6 (Wolery, 1992). The rate should be calculated as a sum of these two linear terms. Higher temperature data can be obtained by using the $25^{\circ} \mathrm{C}$ data, an activation energy of $16 \mathrm{kcal} / \mathrm{mole}$ and the Arrhenius relationship: 


$$
\ln \frac{k_{2}}{k_{1}}=-\frac{E_{a}}{R}\left(\frac{T_{2}-T_{1}}{T_{1} T_{2}}\right)
$$

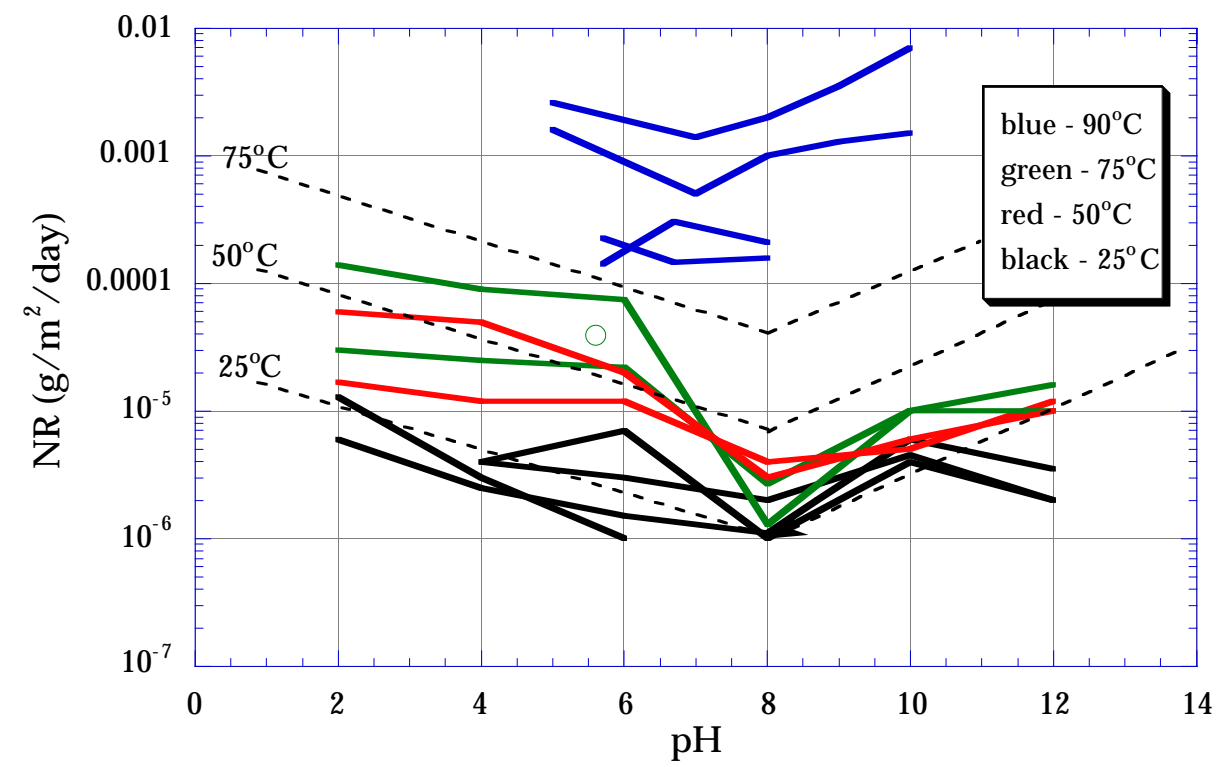

Figure 14. SPFT data for all tests of pyrochlore-based composite ceramics and single-phase zirconolite and pyrochlore. Dashed lines provide $\mathrm{pH}$ and temperature dependence of average rates. Data are from Appendix 1 of this report, Hart et al., 1999a, and McGrail et al., 1999.

Our SPFT and static test data have also been used to provide qualitative information on the relative release rates of actinides and neutron absorbers from the waste form (Table 6). The data show that $\mathrm{Hf}$ is always released more slowly than either $\mathrm{Pu}$ or $\mathrm{U}$ for all the conditions that have been investigated. We have no reliable data for $\mathrm{Hf}$ release rates at high $\mathrm{pHs}$. $\mathrm{Gd}$ generally is released at about the same rate as $U$ at acidic $\mathrm{pH}$ values, and at smaller rates at alkaline $\mathrm{pH}$ values. $\mathrm{Gd}$ appears to be released at about the same rate as $\mathrm{Pu}$ at most $\mathrm{pH}$ values. More data are needed to better define and quantify these relationships.

Table 5. Rate parameters for ceramic dissolution at $25^{\circ} \mathrm{C}$. Parameters are for use in equation $\log ($ rate $)=m * p H+b$

\begin{tabular}{|lcc|}
\hline & Slope (m) & Y-intercept (b) \\
Acid & -0.167 & -4.66 \\
Alkaline & +0.25 & -8 \\
\hline
\end{tabular}

Changes in recommended values from previous input for performance assessment

The most significant changes in our recommended parameters to use in performance assessment include:

1. A lower activation energy implying a slower increase in ceramic degradation rate as a function of temperature than previously estimated. The activation energy used in our previous input (which was estimated on the basis of very few data) was $24 \mathrm{kcal} / \mathrm{mole}$. Our experimental data now suggest a value closer to $16 \mathrm{kcal} / \mathrm{mole}$. 
2. The $\mathrm{pH}$ dependency of the rate is smaller than previously determined. This change results from a statistical evaluation of additional data from laboratories at PNNL, ANSTO, and LLNL.

3. We now provide qualitative data on relative release rates of actinides versus neutron absorbers.

Table 6. Relative release rates of actinides vs. neutron absorbers based on results from SPFT and PCT tests. Data from Appendix 1 of this report, Mc Grail et al. 1999, and Hart et al., 1999a.

\begin{tabular}{|ccccc|}
\hline \multicolumn{2}{c}{ Element vs. U } & \multicolumn{2}{c|}{ Element vs. Pu } \\
$\mathbf{p H}$ & $G d$ & $H f$ & $G d$ & $H f$ \\
$\mathbf{2}$ & $=\mathrm{U}$ & $=\mathrm{U}$ & $=\mathrm{Pu}$ & $=\mathrm{Pu}$ \\
$\mathbf{4}$ & $=\mathrm{U}$ & $<\mathrm{U}$ & $=\mathrm{Pu}$ & $=\mathrm{Pu}$ \\
$\mathbf{6}$ & $=\mathrm{U}$ & $<\mathrm{U}$ & $>\mathrm{Pu}$ & $<\mathrm{Pu}$ \\
$\mathbf{8}$ & $<\mathrm{U}$ & $<\mathrm{U}$ & $=\mathrm{Pu}^{-\#}$ & n.d. \\
$\mathbf{1 0}$ & $<\mathrm{U}$ & $<\mathrm{U}$ & n.d. & n.d. \\
$\mathbf{1 2}$ & $<\mathrm{U}$ & $<\mathrm{U}$ & n.d. & n.d. \\
\hline
\end{tabular}

n.d. no data available; \# - from PCT test results

\section{Conclusions and Outstanding Data Needs}

Although we have a significant database of dissolution rate measurements, there are some key data currently lacking that would help better define a mechanistic model for dissolution of our titanate ceramic.

1. We have no data on $\mathrm{Hf}$ release rates relative to $\mathrm{Pu}$ and $\mathrm{U}$ at high $\mathrm{pH}$ values $(\mathrm{pH}>8)$

2. We have very little information on the compositions and thicknesses of alteration layers. Do the layers thicken with time, or do they spall off, or do they exist at all?

3. We see incongruent dissolution under most conditions. We need to know where the elements released at slower rates are going; do they remain behind in a leached layer or precipitate in alteration minerals? This is important because elements that remain in an intact leached layer can be excluded from colloidal transport mechanisms.

3. Brannerite appears to dissolve much faster than pyrochlore and zirconolite, the other phases that contain most of the actinides. We need to confirm these data and quantify these results for feedback to waste form formulation.

Work over the next year should concentrate in these areas, as well as continue long-term tests.

\section{References}

Bakel A. J., Buck E. C., Merz C. J., and Chamberlain D. B., (1999a) Long-term testing of titanate ceramics for plutonium immobilization, ANL, Report Number PIP-99-073; 11 p.; June 1999. 
Bakel A. J., Buck E. C., Zyryanov V. N., Merz C. J., and and Chamberlain D. B., (1999b) Characterization and corrosion behavior of hafnium-cerium-uranium ceramics containing impurities., ANL, Report Number PIP-99-077; 44 p.; June 1999.

Bakel A. J., Mertz C. J., Nole M. K., and Chamberlain D. B., (1999c) Corrosion behavior of titanate ceramics in short-term MCC-1 tests: results from tests with zirconolite-rich baseline and impurity ceramics., ANL, Report Number draft; 45 p.; July 1999.

Bourcier W. L., (1998) generate models for release of radionuclides and neutron absorbers from titanate ceramic waste forms, LLNL, Report Number UCRL-ID134281; 26 p.; July 1998.

Crank J. (1975) The Mathematics of Diffusion. Clarendon Press.

Crawford C. L., Biddle N. E., and Bibler N. E., (1999) Durability testing of heavy-ionirradiated crystalline ceramics., Westinghouse Savannah River Company, Report Number WSRC-TR-99-00263 Rev. 0; 71 p.; August 1999.

Freer R. (1980) Self diffusion and impurity diffusion in oxides. J. Materials Science 15:803-824.

Hart K. P., Lumpkin G. R., Zhang Y., Loi E., and Leung S., (1999a) Durability and natural mineral studies carried out to support development of waste forms for immobilization of plutonium, ANSTO, Report Number Interim Report; 145 p.; April 30, 1999.

Hart K. P., Zhang Y., Loi E., Day R. A., Colella M., Lumpkin G. R., Stewart M. W., and Bourcier W. L. (1999b) Durability studies on pyrochlore-rich titanate ceramics designed to immobilize excess Pu. Materials Research Society, in press.

Hochella M. F. (1990) Atomic structure, microtopography, composition, and reactivity of mineral surfaces. In Mineral-Water Interface Geochemistry, Vol. 23 (ed. M. F. Hochella and A. F. White), pp. 88-132. Mineralogical Society of America.

Knauss K. G., Bourcier W. L., McKeegan K. D., Merzbacher C. I., Nguyen S. N., Ryerson F. J., Smith D. K., Weed H. C., and Newton L. (1990) Dissolution kinetics of a simple nuclear waste glass as a function of $\mathrm{pH}$, time, and temperature. Mat. Res. Soc. Symp. Proc. 176:371-381.

Knauss K. G., Dibley M. J., and Bourcier W. L., (1999) Ti(IV) hydrolysis constants derived from rutile solubility measurements made from 100 to 300C., LLNL, Report Number draft; 26 p.; June 1999.

Knauss K. G. and Wolery T. J. (1986) Dependence of albite dissolution kinetics on pH and time at $25^{\circ}$ and $70^{\circ}$ C. Geochim. Cosmochim. Acta 50:2481-2497.

Lasaga A. C. (1998) Kinetic Theory in the Earth Sciences. Princeton University Press. 811 p.

Magnussen O. and Behm R. J. (1999) Atomic-scale processes in Cu corrosion and corrosion inhibition. J. Mat. Res. Soc. 24(7):16-23.

McGrail B. P., Martin P. F., Icenhower J. P., Schaef H. T., Legore V. L., and Orr R. D., (1999) Evaluation of the long-term performance of titanate ceramics for immobilization of excess weapons plutonium: results from pressurized unsaturated flow and single pass flow-through testing, PNNL, Report Number PNNL-12240; 37 p.; July 1999.

Mertz C. J., Bakel A. J., Chamberlain D. B., Hash M. C., and Nole M. K., (1999) Status report: Vapor hydration interaction tests for the fissile materials disposition program., ANL, Report Number PIP 99-027; 19 p.; November 1998.

Ryan M. P., Toney M. F., Davenport A. J., and Oblonsky L. J. (1999) In situ X-ray diffraction studies of passive oxide films. Mat. Res. Soc. Bull. 24(7):29-35. 
Shaw H., (1999) Input for Yucca Mountain Total Systems Performance Assessment, Lawrence Livermore national Laboratory, Report Number PIP-99-107; 64 p.; August 1999.

Stout R. B. and Leider H. R., (1998) Waste Forms Characteristics Report, Lawrence Livermore National Laboratory, Report Number UCRL-ID-132375; 656 p.; December 1998.

Van Konynenburg R. A., (1997) Expected radiation effects in plutonium immobilization ceramic, Lawrence Livermore National Laboratory, Report Number UCRL ID 128580; 31 p.; September, 1997.

Velbel M. A. (1986) Influence of surface area, surface characteristics, and solution composition on feldspar weathering rates. In Geochemical Processes at Mineral Surfaces, Vol. 323 (ed. J. Davis and K. Hayes), pp. 613-634. American Chemical Society.

Wolery T. J., (1992) EQ3/6, A software package for geochemical modeling of aqueous systems:Package overview and installation guide, Lawrence Livermore National Laboratory, Report Number UCRL-MA-110662 PT 1; 66 p.; Sept 14, 1992. 


\section{Appendix A. Experimental results from single pass flow-through tests performed at Lawrence Livermore National Laboratory.}

\section{Experimental Methods}

The dissolution rates of baseline multiphase and single phase ceramics (pyrochlore, zirconolite, and brannerite) were measured in $\mathrm{pH}$-buffered solutions of $\mathrm{pH} 2,4,6,8,10$, and 12 at temperatures of 25,50 , and $75^{\circ} \mathrm{C}$ in flow-through reactors. The elemental composition of the ceramics tested are given in Table A1 and the buffer compositions in Table A2.

All the ceramics tested were cold pressed and sintered at $1350^{\circ} \mathrm{C}$ in air, except brannerite which was sintered at $1350^{\circ} \mathrm{C}$ in a $\mathrm{CO} / \mathrm{CO}_{2}$ gas mixture. They were then crushed, sieved, rinsed repeatedly in alcohol and distilled water, and the 10 - 20 micron grain size collected for the single pass flow-through tests (SPFT). The surface area of the ceramics measured by BET ranged from $0.2-0.35 \mathrm{~m}^{2} / \mathrm{g}$. The measured values for each ceramic are shown along with the experimental dissolution data in Table A3.

The single pass flow-through cell allows the powdered ceramic to react with $\mathrm{pH}$ buffer solutions traveling upward vertically through the powder (Fig. A1). Gentle rocking during sampling keeps the powder suspended and avoids clumping, and allows the system to behave as a continuously stirred reactor. For each ceramic phase, a cells was loaded with approximately one gram of the 10 - 20 micron size fraction of powdered ceramic and reacted with a buffer solution of the desired $\mathrm{pH}$. Tests were run at 25,50 , and $75^{\circ} \mathrm{C}$. A debubbler cell, which allows the gas exsolved during heating at elevated temperatures to escape, was placed in line for each buffer solution. The flow-through tests were run at various flow rates ranging from 10 to over $100 \mathrm{ml} / \mathrm{day}$. The flow rates are given in Table A3 for each test as a function of time. Peristaltic pumps were used to control flow rate. 
Figure. A1. Schematic of single pass flow through apparatus.

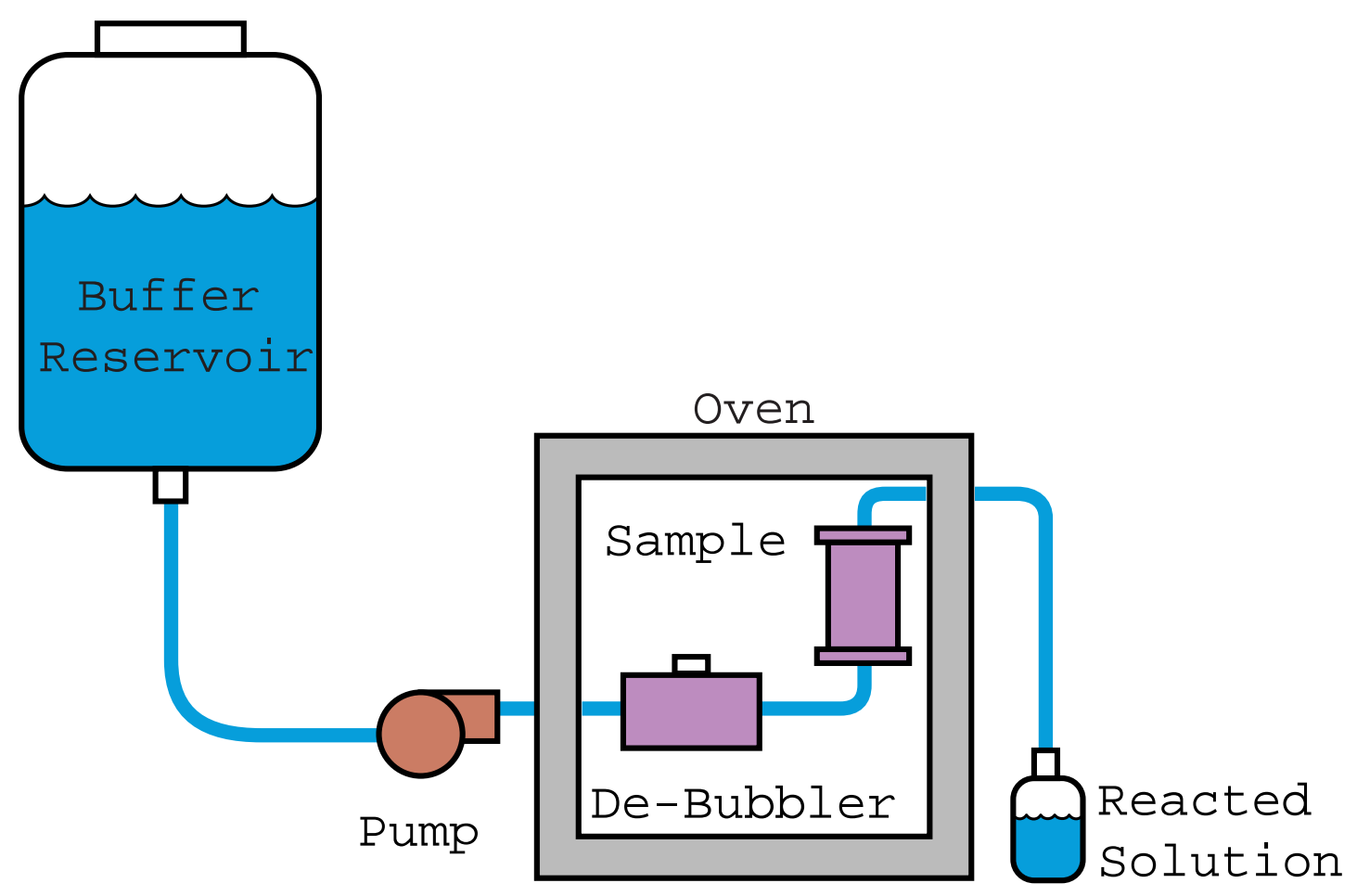

The reacted solution was periodically sampled, weighed to determine flow rates, and analyzed by ICP/MS for cerium, gadolinium, hafnium, titanium, and uranium. The concentration data were used to compute the normalized release rate is defined as:

$$
N R_{i}=\frac{C_{i} * Q_{i}}{S * m * X_{i} * \rho}
$$

where $C_{i}$ is the blank corrected concentration of element $i$ in the buffered leach solution, $Q$ is the solution flow rate, $S$ is the BET-measured specific surface area of the ceramic, $m$ is the mass of ceramic, $X_{i}$ is the weight fraction of element $i$ in the ceramic,.and $\mathrm{r}$ is the density of the solution. Normalized rates are given in Table A3 in units of $\mathrm{g} / \mathrm{m}^{2} / \mathrm{day}$. 
Table A1. Compositions of ceramics used in SPFT dissolution tests.

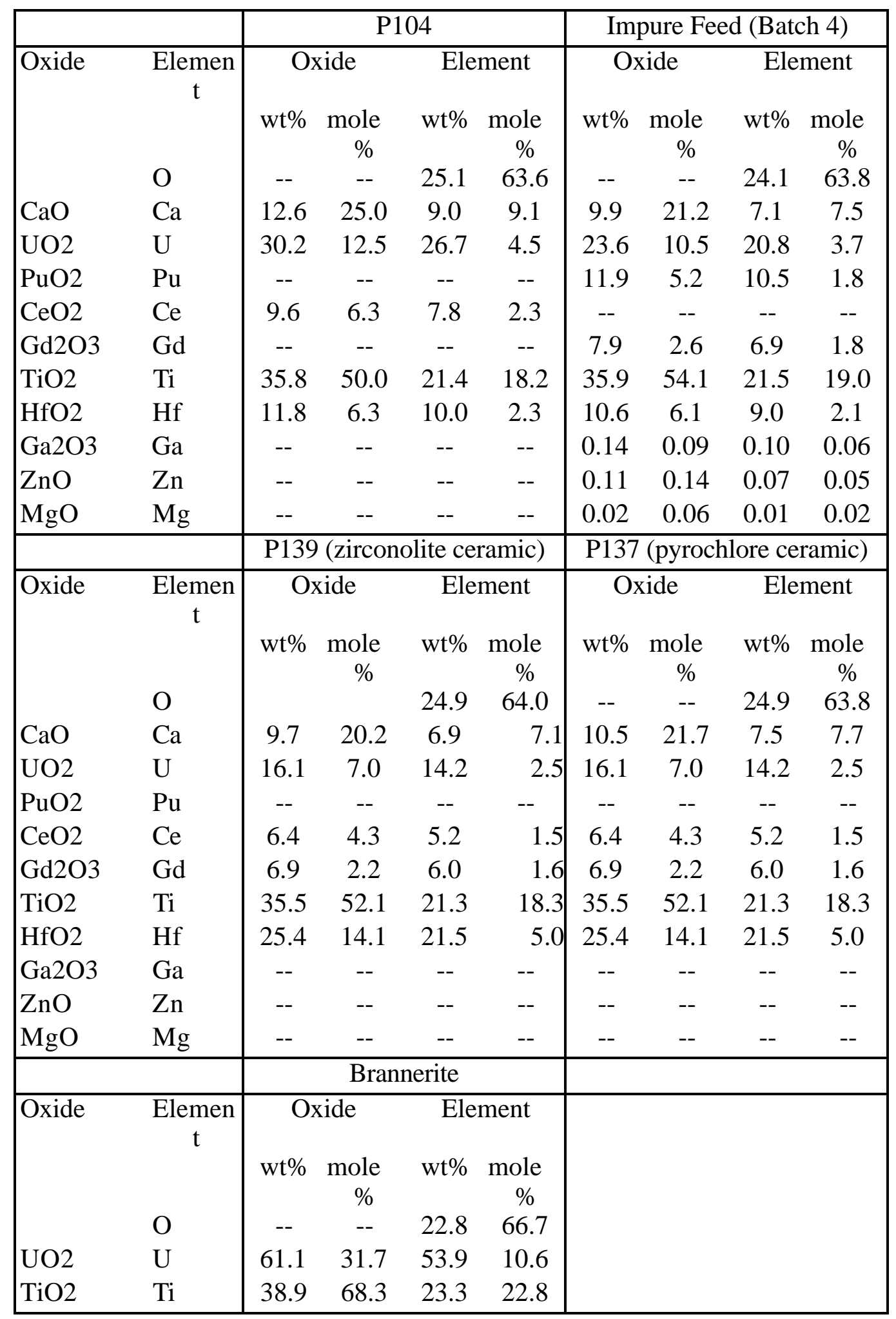


Table A2. Buffer solutions.

\begin{tabular}{|c|c|c|}
\hline $\mathrm{pH} 2$ & $\mathrm{HCl}$ & 0.01 molal \\
\hline $\mathrm{pH} 4$ & Potassium acid phthalate $/ \mathrm{HCl}$ & 0.005 molal \\
\hline pH6 & Potassium acid phthalate $/ \mathrm{NaOH}$ & 0.005 molal \\
\hline pH 8 & $\mathrm{NaHCO}_{3}$ & 0.005 molal \\
\hline $\mathrm{pH} 8$ & Boric acid/NaOH & 0.005 molal \\
\hline $\mathrm{pH} 10$ & Boric acid/NaOH & 0.005 molal \\
\hline $\mathrm{pH} 12$ & $\mathrm{NaCl} / \mathrm{NaOH}$ & 0.01 molal \\
\hline $\mathrm{pH} 12$ & $\mathrm{Na}_{2} \mathrm{CO}_{3} / \mathrm{NaOH}$ & 0.01 molal \\
\hline $\mathrm{pH} 12$ & $\mathrm{KH}_{2} \mathrm{PO}_{4} / \mathrm{NaOH}$ & 0.01 molal \\
\hline
\end{tabular}

\section{Experimental Results}

The following tables contain all available raw data from the SPFT tests performed at Lawrence Livermore National Laboratory. 
Table A3. SPFT test results: (a) Ce-U ceramic at $25^{\circ} \mathrm{C}$; (b) $\mathrm{Pu}-\mathrm{U}$ ceramic at $25^{\circ} \mathrm{C}$; (c) Single phase pyrochlore at 25,50 , and $75^{\circ} \mathrm{C}$. (d) Single phase zirconolite at 25,50 , and $75^{\circ} \mathrm{C}$. 


\begin{tabular}{|c|c|c|c|c|c|c|c|c|c|c|c|c|c|c|c|c|c|c|c|c|c|c|c|}
\hline multiphas & se cerar & nic at 25 & $\mathrm{oC}$; (c) S & Single $\mathrm{ph}$ & ase $p$ & rochlor & cerami & $c$ at 25 , & 50 , and & $750 \mathrm{C}$ & (d) $\operatorname{Sin}$ & phase & zirconolit & & & & & & & & & & \\
\hline ceramic & at 25,5 & 0 , and 75 & 5oc. & & & & & & & & & & & & & & & & & & & & \\
\hline (a) Pu-U & J Ceram & ic $25 \mathrm{C}$ & $(\mathrm{pH} 2,4$ & 4, 6) & & & & & & & & & & & & & & & & & & & \\
\hline Experin & ments Start & ed on: & & & & & & & & & & & & & & & & & & & & & \\
\hline & $7 / 23 / 0$ & & & & & & & & & & & & & & & & & & & & & & \\
\hline Sample: Pu-L & U Ceramics & & & & & & & & & & & & & & & & & & & & & & \\
\hline $\begin{array}{l}\text { tarting } S A= \\
\text { rdenity }\end{array}$ & 0.30 & $m^{\wedge} 2 / g$ & & & & & & & & & & & & & & & & & & & & & \\
\hline density = & $\begin{array}{c}2.70 \\
2.7 E-12\end{array}$ & $\begin{array}{l}\mathrm{g} / \mathrm{cm}^{\wedge} 3 \\
\mathrm{~g} / \mathrm{u}^{\wedge} 3\end{array}$ & & & & & & & & & & & & & & & & & & & & & \\
\hline & Element & WtFract & Element & & & & & & & & & & & & & & & & & & & & \\
\hline & $\mathrm{Ti}$ & 0.215 & & & & & & & & & & & & & & & & & & & & & \\
\hline & 0 & 0.241 & & & & & & & & & & & & & & & & & & & & & \\
\hline & $u$ & 0.208 & & & & & & & & & & & & & & & & & & & & & \\
\hline & $\begin{array}{l}\mathrm{Pu} \\
\mathrm{HF}\end{array}$ & $\begin{array}{l}0.105 \\
0.090\end{array}$ & & & & & & & & & & & & & & & & & & & & & \\
\hline & $\mathrm{Ca}$ & 0.071 & & & & & & & & & & & & & & & & & & & & & \\
\hline & $\mathrm{Gd}$ & 0.069 & & & & & & & & & & & & & & & & & & & & & \\
\hline & $\mathrm{Ga}$ & 0.001 & & & & & & & & & & & & & & & & & & & & & \\
\hline & $\mathrm{Zn}$ & 0.001 & & & & & & & & & & & & & & & & & & & & & \\
\hline & $\begin{array}{c}\mathrm{Mg} \\
\text { sum } \\
\text { sul }\end{array}$ & $\begin{array}{l}0.000 \\
11000\end{array}$ & & & & & & & & & & & & & & & & & & & & & \\
\hline $25 \mathrm{C}$ data & Mass & Flow Rate & Run time & SurfArea & & & & & & & & & & & & & & & & & & & \\
\hline pH 2 & (g) & $(\mathrm{mL} / \mathrm{day})$ & (days) & (sq. m) & $\mathrm{pH}$ & $\mathrm{Pu}$ & u & $\mathrm{Hf}$ & Gd & $\mathrm{Ga}$ & $\mathrm{Ca}$ & $\mathrm{Ti}$ & Zn & $\mathrm{Mg}$ & NR-Pu(pH2) & $\mathrm{NR}-\mathrm{U}(\mathrm{pH} 2)$ & NR-Hf & NR-Gd(pH2) & NR-Ga & NR-Ca & NR-T & NR-Zn & NR-Mg \\
\hline $\begin{array}{l}\text { start } \\
\text { Pu201 }\end{array}$ & $\begin{array}{l}1.00 \\
1.00\end{array}$ & 14.85 & 0.35 & $\begin{array}{l}0.30 \\
0.30\end{array}$ & 2.6 & $\begin{array}{c}\mathrm{ppb} \\
20.65\end{array}$ & $\mathrm{ppb}$ & $\mathrm{ppb}$ & $\mathrm{ppb}$ & $\mathrm{ppb}$ & $\mathrm{ppb}$ & $\mathrm{ppb}$ & $\mathrm{ppb}$ & $\mathrm{ppb}$ & 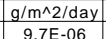 & $g / m^{\wedge} 2 / d a y$ & $\mathrm{~g} / \mathrm{m}^{\wedge} 2 / \mathrm{day}$ & $g / m^{\wedge} 2 / d a y$ & $\mathrm{~g} / \mathrm{m}^{\wedge} 2 / \mathrm{day}$ & $\mathrm{g} / \mathrm{m}^{\wedge} 2 / \mathrm{day}$ & $\mathrm{g} / \mathrm{m}^{\wedge} 2 / \mathrm{day}$ & $g / m^{\wedge} 2 / d a y$ & $g / m^{\wedge} 2 / d a y$ \\
\hline \begin{tabular}{|l|l|} 
Pu202 \\
\end{tabular} & 1.00 & 14.88 & 1.20 & 0.30 & 2.6 & 41.04 & 1467.0 & 1.4 & 4862.0 & & & 161.0 & & & $1.9 \mathrm{E}-05$ & $3.5 \mathrm{E}-04$ & 7.7E-07 & $3.5 \mathrm{E}-03$ & & & 3.7E-05 & & \\
\hline Pu203 & 1.00 & 14.84 & 2.40 & 0.30 & 2.5 & 47.18 & 953.0 & 2.4 & 1148.0 & & & 571.0 & & & $2.2 \mathrm{E}-05$ & $2.3 \mathrm{E}-04$ & $1.3 \mathrm{E}-06$ & $8.3 \mathrm{E}-04$ & & & $1.3 \mathrm{E}-04$ & & \\
\hline Pu204 & 1.00 & 15.04 & 3.01 & 0.30 & 2.4 & 46.03 & & & & & & & & & $2.2 \mathrm{E}-05$ & & & & & & & & \\
\hline Pu205 & 1.00 & 14.84 & 5.84 & 0.30 & 2.4 & 58.74 & & & & & & & & & $2.8 \mathrm{E}-05$ & & & & & & & & \\
\hline Pu206 & 1.00 & 14.84 & 7.87 & 0.30 & 2.5 & 70.98 & & & & & & & & & 3.3E- 05 & & & & & & & & \\
\hline Pu207 & 1.00 & 14.91 & 9.88 & 0.30 & 2.6 & 78.01 & & & & & & & & & 3.7E-05 & & & & & & & & \\
\hline Pu208 & 1.00 & 15.00 & 12.90 & 0.30 & 2.5 & 86.29 & & & & & & & & & $4.1 \mathrm{E}-05$ & & & & & & & & \\
\hline Pu209 & 1.00 & 15.04 & 15.88 & 0.30 & 2.5 & 88.23 & & & & & & & & & 4.2E-05 & & & & & & & & \\
\hline Pu210 & 1.00 & 14.99 & 19.88 & 0.30 & 2.6 & 98.17 & & & & & & & & & 4.7E-05 & & & & & & & & \\
\hline $\begin{array}{l}\text { Pu211 } \\
\text { Pu212 }\end{array}$ & 0.99 & $\begin{array}{l}14.97 \\
15.01\end{array}$ & $\begin{array}{l}22.86 \\
26.86\end{array}$ & 0.30 & 2.6 & 98.77 & & & & & & & & & 4.7E-05 & & & & & & & & \\
\hline $\begin{array}{l}\text { Pu212 } \\
\text { Pu213 }\end{array}$ & $\begin{array}{l}0.99 \\
0.99\end{array}$ & $\begin{array}{l}15.01 \\
15.03\end{array}$ & $\begin{array}{l}26.86 \\
29.89\end{array}$ & $\begin{array}{l}0.30 \\
0.30\end{array}$ & $\begin{array}{l}2.6 \\
2.6\end{array}$ & $\begin{array}{l}95.03 \\
95.03\end{array}$ & & & & & & & & & $\begin{array}{l}4.5 \mathrm{E}-05 \\
4.6 \mathrm{E}-05\end{array}$ & & & & & & & & \\
\hline Pu214 & $\begin{array}{l}0.99 \\
0.99\end{array}$ & 15.18 & $\begin{array}{l}29.89 \\
37.91\end{array}$ & 0.30 & $\begin{array}{l}2.6 \\
2.5\end{array}$ & $\begin{array}{l}93.03 \\
92.21\end{array}$ & & & & & & & & & $\begin{array}{l}4.0 \mathrm{E}-05 \\
4.5 \mathrm{E}-05\end{array}$ & & & & & & & & \\
\hline Pu215 & 0.99 & 30.23 & 48.88 & 0.30 & 2.5 & 58.62 & 236.0 & $\mathrm{ND}<0.5$ & 76.0 & & & 273.0 & & & $5.7 \mathrm{E}-05$ & $1.2 \mathrm{E}-04$ & & 1.1E-04 & & & $1.3 \mathrm{E}-04$ & & \\
\hline Pu216 & 0.98 & 30.21 & 51.83 & 0.30 & 2.4 & 54.55 & & & & & & & & & $5.3 \mathrm{E}-05$ & & & & & & & & \\
\hline Pu217 & 0.98 & 30.21 & 55.90 & 0.30 & 2.5 & 48.67 & 189.0 & $\mathrm{ND}<0.5$ & 59.0 & & & 179.0 & & & $4.7 E-05$ & $9.2 \mathrm{E}-05$ & & $8.8 \mathrm{E}-05$ & & & $8.5 \mathrm{E}-05$ & & \\
\hline Pu218 & 0.98 & 30.30 & 58.83 & 0.30 & 2.5 & 43.50 & & & & & & & & & $4.2 \mathrm{E}-05$ & & & & & & & & \\
\hline Pu219 & 0.98 & 30.44 & 62.39 & 0.30 & 2.4 & 43.20 & 118.0 & $\mathrm{ND}<0.5$ & 40.0 & & & 126.0 & & & $4.2 \mathrm{E}-05$ & $5.8 \mathrm{E}-05$ & & $6.0 \mathrm{E}-05$ & & & $6.0 \mathrm{E}-05$ & & \\
\hline Pu220 & 0.98 & 30.26 & 65.82 & 0.30 & 2.5 & 41.22 & & & & & & & & & $4.0 E-05$ & & & & & & & & \\
\hline Pu221 & 0.98 & 30.26 & 69.86 & 0.30 & 2.5 & 39.46 & 83.0 & $\mathrm{ND}<0.5$ & 28.0 & & & 87.0 & & & $3.8 \mathrm{E}-05$ & $4.1 \mathrm{E}-05$ & & $4.2 \mathrm{E}-05$ & & & 4.1E-05 & & \\
\hline Pu222 & 0.98 & 30.29 & 72.88 & 0.30 & 2.4 & 37.79 & & & & & & & & & 3.7E-05 & & & & & & & & \\
\hline Pu223 & 0.98 & 32.31 & 76.89 & 0.30 & 2.5 & 33.58 & 69.0 & 0.6 & 23.0 & & & 72.0 & & & 3.5E-05 & $3.6 \mathrm{E}-05$ & $7.3 \mathrm{E}-07$ & 3.7E- 05 & & & 3.7E-05 & & \\
\hline $\begin{array}{l}\text { Pu224 } \\
\text { Pu25 }\end{array}$ & 0.98 & $\begin{array}{l}32.01 \\
30.97\end{array}$ & $\begin{array}{l}83.86 \\
86.87\end{array}$ & $\begin{array}{l}0.30 \\
0.30\end{array}$ & $\begin{array}{l}2.4 \\
2.5\end{array}$ & 31.30 & & & & & & & & & 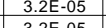 & & & & & & & & \\
\hline $\begin{array}{l}\text { Pu225 } \\
\text { Pu226 }\end{array}$ & $\begin{array}{l}0.98 \\
0.97\end{array}$ & $\begin{array}{l}30.97 \\
31.28\end{array}$ & $\begin{array}{l}86.87 \\
90.94\end{array}$ & $\begin{array}{l}0.30 \\
0.29\end{array}$ & $\begin{array}{l}2.5 \\
2.5\end{array}$ & $\begin{array}{l}31.90 \\
30.88\end{array}$ & 66.0 & 0.9 & 22.0 & & & 67.0 & & & $\begin{array}{l}3.2 \mathrm{E}-05 \\
3.1 \mathrm{E}-05\end{array}$ & $3.3 \mathrm{E}-05$ & $1.1 \mathrm{E}-06$ & 3.4E-05 & & & $3.3 \mathrm{E}-05$ & & \\
\hline Pu227 & 0.97 & 30.88 & $\begin{array}{l}90.94 \\
93.90\end{array}$ & $\begin{array}{l}0.29 \\
0.29\end{array}$ & $\begin{array}{l}2.5 \\
2.5\end{array}$ & $\begin{array}{l}30.88 \\
29.67\end{array}$ & 63.0 & 1.2 & 21.0 & & & 62.0 & & & $\begin{array}{l}3.1 \mathrm{E}-05 \\
3.0 \mathrm{E}-05\end{array}$ & $3.2 \mathrm{E}-05$ & $1.4 \mathrm{E}-06$ & $3.2 \mathrm{E}-05$ & & & $3.0 \mathrm{E}-05$ & & \\
\hline Pu228 & 0.97 & 8.64 & 98.31 & 0.29 & 2.5 & 87.83 & 63.0 & 1.2 & & & & 62.0 & & & $\begin{array}{l}\text {.0E-05 } \\
2.5 \mathrm{E}-05\end{array}$ & $0 . \angle L-O 0^{2}$ & $1.4 E-06$ & $0.2 L-00$ & & & $0.0[-00$ & & \\
\hline Pu229 & 0.97 & 8.65 & 105.01 & 0.29 & 2.5 & 88.87 & 203.0 & 3.3 & 64.0 & & & 165.0 & & & $2.5 \mathrm{E}-05$ & $2.9 \mathrm{E}-05$ & $1.1 \mathrm{E}-06$ & $2.7 \mathrm{E}-05$ & & & $2.3 \mathrm{E}-05$ & & \\
\hline Pu230 & 0.97 & 8.68 & 113.04 & 0.29 & 2.5 & 85.92 & 195.0 & 4.4 & 63.0 & 1.2 & 91.9 & 165.3 & $4.6 \mathrm{E}+01$ & & $2.4 \mathrm{E}-05$ & $2.8 \mathrm{E}$ & $1.4 \mathrm{E}-06$ & $2.7 \mathrm{E}-05$ & $3.5 \mathrm{E}-05$ & $3.8 \mathrm{E}-05$ & $2.3 \mathrm{E}-05$ & $1.9 \mathrm{E}-03$ & \\
\hline Pu231 & & 47 & 119.91 & 0.29 & 2.3 & 18.32 & 61.0 & 5.8 & 15.0 & & 51.1 & 75.5 & $3.2 \mathrm{E}+01$ & & $2.8 \mathrm{E}-05$ & $4.7 \mathrm{E}-05$ & $1.0 \mathrm{E}-05$ & $3.5 \mathrm{E}-05$ & & $1.2 \mathrm{E}-04$ & $5.6 \mathrm{E}-05$ & $7.3 \mathrm{E}-03$ & \\
\hline Pu232 & 0.97 & 46.94 & 125.39 & 0.29 & 2.5 & 17.20 & 38.0 & 2.4 & 10.6 & $\mathrm{ND}<1$ & 13.6 & 31.2 & $2.4 \mathrm{E}+00$ & & $2.6 \mathrm{E}-05$ & $2.9 \mathrm{E}-05$ & $4.3 \mathrm{E}-06$ & $2.5 \mathrm{E}-05$ & & $3.1 \mathrm{E}-05$ & $2.3 \mathrm{E}-05$ & $5.5 \mathrm{E}-04$ & \\
\hline Pu233 & 0.97 & 47.04 & 132.92 & 0.29 & 2.3 & 14.56 & 41.0 & 3.4 & 11.8 & $N D<1$ & 25.0 & 34.7 & $2.4 \mathrm{E}+01$ & & $2.2 \mathrm{E}-05$ & $3.2 \mathrm{E}-05$ & $6.1 \mathrm{E}-06$ & $2.8 \mathrm{E}-05$ & & $5.7 \mathrm{E}-05$ & $2.6 \mathrm{E}-05$ & $5.5 \mathrm{E}-03$ & \\
\hline Pu234 & 0.96 & 46.82 & 139.88 & 0.29 & 2.3 & 14.09 & 33.0 & 3.1 & 8.9 & $N D<1$ & 22.0 & 25.6 & $2.8 \mathrm{E}+01$ & & $2.1 \mathrm{E}-05$ & $2.5 \mathrm{E}-05$ & $5.5 \mathrm{E}-06$ & $2.1 \mathrm{E}-05$ & & $5.0 \mathrm{E}-05$ & $1.9 \mathrm{E}-05$ & $6.3 \mathrm{E}-03$ & \\
\hline Pu235 & 0.96 & 46.87 & 146.85 & 0.29 & 2.5 & 13.46 & 31.0 & 3.7 & 8.5 & $N D<1$ & 24.5 & 24.8 & $3.4 \mathrm{E}+01$ & & $2.1 \mathrm{E}-05$ & 2.4E-05 & $6.6 \mathrm{E}-06$ & $2.0 \mathrm{E}-05$ & & $5.5 \mathrm{E}-05$ & $1.8 \mathrm{E}-05$ & 7.7E-03 & \\
\hline Pu236 & 0.96 & 46.78 & 152.88 & 0.29 & 2.4 & 12.91 & 35.0 & 4.5 & 9.6 & $N D<1$ & 21.4 & 26.9 & $2.4 \mathrm{E}+01$ & & $2.0 \mathrm{E}-05$ & 2.7 & 8.0 & 2.2E-05 & & 4.8 & $2.0 \mathrm{E}-05$ & 5.4E- 03 & \\
\hline Pu237 & 0.96 & 61.94 & 168.01 & 0.2 & 2.6 & 11.24 & 32.0 & 18.0 & 8.7 & $N D<1$ & 41.5 & 42.7 & $7.5 \mathrm{E}+01$ & & $2.3 \mathrm{E}-05$ & $3.3 \mathrm{E}-05$ & $4.2 \mathrm{E}-05$ & 05 & & 04 & $4.2 \mathrm{E}-05$ & $2.3 \mathrm{E}-02$ & \\
\hline $\begin{array}{l}\text { Pu238 } \\
\text { Pu2339 }\end{array}$ & 0.96 & 61.17 & $\begin{array}{l}174.85 \\
\end{array}$ & 0.29 & $\begin{array}{l}2.6 \\
2.5\end{array}$ & $\begin{array}{l}10.14 \\
\end{array}$ & 24.0 & 4.8 & 6.1 & $N D<1$ & $\begin{array}{l}13.6 \\
\end{array}$ & 18.3 & $5.1 \mathrm{E}+01$ & & $2.0 \mathrm{E}-05$ & 2.4E-05 & 1.1E-05 & $\begin{array}{l}1.9 E-05 \\
19 E-05\end{array}$ & & 4.0E-05 & $\begin{array}{l}1.8 \mathrm{E}-05 \\
1\end{array}$ & $1.5 \mathrm{E}-02$ & \\
\hline 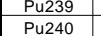 & $\begin{array}{l}0.96 \\
0.96\end{array}$ & $\begin{array}{l}61.35 \\
61.23 \\
61.23\end{array}$ & $\begin{array}{l}181.88 \\
188.92\end{array}$ & $\begin{array}{l}0.29 \\
0.29\end{array}$ & $\begin{array}{l}2.5 \\
2.4\end{array}$ & $\begin{array}{l}9.16 \\
8.96\end{array}$ & $\begin{array}{l}24.0 \\
25.0\end{array}$ & $\begin{array}{l}4.4 \\
4.9\end{array}$ & $\begin{array}{l}5.8 \\
6.1\end{array}$ & $\begin{array}{l}\mathrm{ND}<1 \\
\mathrm{ND}<1\end{array}$ & $\begin{array}{l}17.4 \\
16.6\end{array}$ & $\begin{array}{l}16.8 \\
17.6\end{array}$ & & & $\begin{array}{r}1.8 \mathrm{E}-05 \\
1.8 \mathrm{E}-5\end{array}$ & $\begin{array}{l}2.4 \mathrm{E}-05 \\
2.5 \mathrm{E}-5\end{array}$ & $\begin{array}{l}1.0 \mathrm{E}-05 \\
1.1 \mathrm{E}-05\end{array}$ & $\begin{array}{l}1.8 \mathrm{E}-05 \\
1.9 \mathrm{E}-05\end{array}$ & & $\begin{array}{l}5.2 \mathrm{E}-05 \\
\end{array}$ & $\begin{array}{l}1.6 \mathrm{E}-05 \\
1 . \mathrm{E}-05\end{array}$ & $6 \mathrm{E}-03$ & \\
\hline $\begin{array}{l}\begin{array}{l}\text { Pu240 } \\
\text { Pu241 }\end{array}\end{array}$ & $\begin{array}{l}0.96 \\
0.96\end{array}$ & $\begin{array}{l}61.23 \\
61.88\end{array}$ & $\begin{array}{l}188.92 \\
195.91\end{array}$ & $\begin{array}{l}0.29 \\
0.29\end{array}$ & $\begin{array}{l}2.4 \\
2.4\end{array}$ & $\begin{array}{l}8.96 \\
8.01\end{array}$ & $\begin{array}{l}25.0 \\
25.0\end{array}$ & $\begin{array}{l}4.9 \\
4.6\end{array}$ & $\begin{array}{l}6.1 \\
6.0\end{array}$ & $\begin{array}{l}\mathrm{NDD}<1 \\
\mathrm{ND}<1\end{array}$ & $\begin{array}{l}16.6 \\
21.1\end{array}$ & $\begin{array}{l}17.6 \\
16.7\end{array}$ & $\begin{array}{l}2.5 \mathrm{E}+01 \\
2.4 \mathrm{E}+01\end{array}$ & & $\begin{array}{l}1.8 \mathrm{E}-05 \\
1.6 \mathrm{E}-05\end{array}$ & $\begin{array}{l}2.5 \mathrm{E}-05 \\
2.6 \mathrm{E}-05\end{array}$ & $\begin{array}{l}1.1 \mathrm{E}-05 \\
1.1 \mathrm{E}-05\end{array}$ & $\begin{array}{l}1.9 \mathrm{E}-05 \\
1.9 \mathrm{E}-05\end{array}$ & & $\begin{array}{l}4.9 \mathrm{E}-05 \\
6.3 \mathrm{E}-05\end{array}$ & $\begin{array}{l}1.7 \mathrm{E}-05 \\
1.6 \mathrm{E}-05\end{array}$ & $\begin{array}{l}7.6 E-03 \\
72 E-03\end{array}$ & \\
\hline Pu242 & 0.96 & 60.73 & 202.88 & 0.29 & 2.3 & 8.35 & 24.0 & 4.7 & 5.9 & $\mathrm{ND}<1$ & 22.5 & 16.7 & $3.0 \mathrm{E}+01$ & & $\begin{array}{l}1.0 \mathrm{E}-05 \\
.7 \mathrm{E}-05\end{array}$ & $2.4 \mathrm{E}-05$ & 1.1E-05 & $1.8 \mathrm{E}-05$ & & $\begin{array}{l}0.0 \mathrm{E}-05 \\
6.6 \mathrm{E}-05\end{array}$ & $\begin{array}{l}1.0 \mathrm{E}-05 \\
1.6 \mathrm{E}-05\end{array}$ & $9.0 E-03$ & \\
\hline Pu243 & 0.96 & 61.39 & 209.88 & 0.2 & 2.3 & 8.08 & 23.0 & 4.8 & 5.5 & $N D<1$ & 12.7 & 16.0 & $2.3 \mathrm{E}+01$ & & 1.6 & 2.3 & 1.1 & 1.7 & & $3.8 \mathrm{E}-05$ & $1.6 \mathrm{E}-05$ & $6.8 \mathrm{E}-03$ & \\
\hline Pu244 & 0.96 & 61.46 & 216.88 & 0.29 & 2.2 & 7.59 & 22.0 & 5.1 & 5.4 & $N D<1$ & 16.1 & 14.5 & 2.1E+01 & & 1. & 2.2E-05 & 1.2E-05 & 1.7E-05 & & $4.8 \mathrm{E}-05$ & 1.4E-05 & $6.3 \mathrm{E}-03$ & \\
\hline $\begin{array}{l}\text { Pu245 } \\
\text { Pu246 }\end{array}$ & 0.95 & 61.44 & $\begin{array}{l}223.89 \\
\end{array}$ & 0.29 & 2.1 & 6.61 & $\begin{array}{l}24.0 \\
220\end{array}$ & 5.1 & $\begin{array}{l}5.8 \\
5 ?\end{array}$ & $\begin{array}{l}N D<1 \\
N D<1\end{array}$ & 20.3 & $\begin{array}{l}15.8 \\
110.8\end{array}$ & $3.2 \mathrm{E}+01$ & & $\begin{array}{l}1.3 \mathrm{E}-05 \\
1.20-05\end{array}$ & 2.4E-05 & $\begin{array}{l}1.2 \mathrm{E}-05 \\
\end{array}$ & $1.8 \mathrm{E}-05$ & & $6.1 \mathrm{E}-05$ & $1.6 \mathrm{E}-05$ & $9.5 E-03$ & \\
\hline $\begin{array}{l}\text { Pu246 } \\
\text { Pu247 }\end{array}$ & $\begin{array}{l}0.95 \\
0.95\end{array}$ & $\begin{array}{l}61.31 \\
74.75\end{array}$ & $\begin{array}{l}237.83 \\
244.84\end{array}$ & 0.29 & 2.1 & 6.00 & $\begin{array}{l}22.0 \\
26.0\end{array}$ & 1.4 & $\begin{array}{l}5.2 \\
6.7\end{array}$ & $\begin{array}{l}N D<1 \\
N D<1\end{array}$ & & $\begin{array}{l}10.8 \\
166\end{array}$ & $\begin{array}{l}6.5 \mathrm{E}+01 \\
\end{array}$ & & $\begin{array}{r}1.2 E-05 \\
1.5-0.05\end{array}$ & $\begin{array}{l}2.2 \mathrm{E}-05 \\
3.2 \mathrm{E}-5\end{array}$ & $\begin{array}{l}3.3 \mathrm{E}-06 \\
1 . \mathrm{F}-0 .\end{array}$ & $\begin{array}{l}1.6 \mathrm{E}-05 \\
2.5 \mathrm{E}-05\end{array}$ & & & $1.1 \mathrm{E}-05$ & $\begin{array}{l}1.9 \mathrm{E}-02 \\
\end{array}$ & \\
\hline 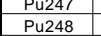 & $\begin{array}{l}0.95 \\
0.95\end{array}$ & $\begin{array}{l}74.75 \\
74.96\end{array}$ & $\begin{array}{l}244.84 \\
245.82\end{array}$ & $\begin{array}{l}0.29 \\
0.29\end{array}$ & $\begin{array}{l}2.1 \\
2.1\end{array}$ & $\begin{array}{l}6.07 \\
5.95\end{array}$ & $\begin{array}{l}26.0 \\
23.0\end{array}$ & $\begin{array}{l}4.9 \\
6.5\end{array}$ & $\begin{array}{l}6.7 \\
5.6\end{array}$ & $\begin{array}{l}\mathrm{NDD}<1 \\
\mathrm{ND}<1\end{array}$ & & $\begin{array}{l}16.6 \\
14.8\end{array}$ & $\begin{array}{l}8.8 \mathrm{E}+01 \\
5.7 \mathrm{E}+1\end{array}$ & & $\begin{array}{r}.155-05 \\
1.5 E-05\end{array}$ & $\begin{array}{l}3.2 \mathrm{E}-05 \\
2 . \mathrm{E}-05\end{array}$ & $\begin{array}{r}1.4 \mathrm{E}-05 \\
1.5 \mathrm{E}-5\end{array}$ & $\begin{array}{l}2.5 \mathrm{E}-05 \\
2 . \mathrm{E}-05\end{array}$ & & & $\begin{array}{l}2.0 \mathrm{E}-05 \\
1.8 \mathrm{E}-05\end{array}$ & $\begin{array}{l}3.2 E-L 22 \\
2.1 E-02\end{array}$ & \\
\hline $\begin{array}{l}\text { Pu249 } \\
\text {. }\end{array}$ & 0.95 & 77.98 & 24 & 0.29 & 2.1 & $\begin{array}{l}.535 \\
6.06\end{array}$ & 20.0 & 5.5 & $\begin{array}{l}.0 .6 \\
4.9\end{array}$ & $\mathrm{ND}<1$ & & 12.6 & $5.3 \mathrm{E}+01$ & & $\begin{array}{l}1.5 \mathrm{E}-05 \\
\end{array}$ & $2.6 \mathrm{E}-05$ & 1.6E-05 & $\begin{array}{l}2.1 \mathrm{TE}-5 \\
1.9 \mathrm{E}-05\end{array}$ & & & $\begin{array}{l}1.8 \mathrm{E}-05 \\
1.6 \mathrm{E}-05\end{array}$ & $\begin{array}{l}2.1 E-02 \\
2.0 E-02\end{array}$ & \\
\hline Pu250 & 0.95 & 78 & & 0. & 2.1 & 6.40 & 21.0 & 4.4 & 5.1 & $N D<1$ & & 16.8 & $2.0 \mathrm{E}$ & & 1. & 2.7 & 05 & 2. & & & 05 & 7.7E-03 & \\
\hline $\begin{array}{l}\text { Pu251 } \\
\text { Pu252 }\end{array}$ & $\begin{array}{l}0.95 \\
0.95\end{array}$ & $\begin{array}{l}78.71 \\
78.41\end{array}$ & $\begin{array}{l}250.84 \\
254.90\end{array}$ & $\begin{array}{l}0.29 \\
0.29\end{array}$ & $\begin{array}{l}2.2 \\
2.1\end{array}$ & $\begin{array}{l}6.07 \\
6.14\end{array}$ & $\begin{array}{l}21.0 \\
21.0\end{array}$ & $\begin{array}{l}4.2 \\
3.4\end{array}$ & $\begin{array}{l}5.3 \\
5.3 \\
\end{array}$ & $\begin{array}{l}\mathrm{NDD}<1 \\
\mathrm{ND}<1\end{array}$ & & $\begin{array}{l}14.1 \\
16.3\end{array}$ & $\begin{array}{l}2.4 \mathrm{E}+01 \\
2.0 \mathrm{E}+01\end{array}$ & & $\begin{array}{l}1.6 \mathrm{E}-05 \\
1.6 \mathrm{E}-05\end{array}$ & $\begin{array}{l}2.7 \mathrm{E}-05 \\
2.7 \mathrm{E}-05\end{array}$ & $\begin{array}{l}1.3 \mathrm{E}-05 \\
1.0 \mathrm{E}-05\end{array}$ & 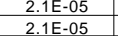 & & & $\begin{array}{l}1.8 \mathrm{E}-05 \\
2.0 \mathrm{E}-05\end{array}$ & $\begin{array}{l}9.4 \mathrm{E}-03 \\
7.8 \mathrm{E}-03\end{array}$ & \\
\hline
\end{tabular}


SPFT Data Table

\begin{tabular}{|c|c|c|c|c|c|c|c|c|c|c|c|c|c|c|c|c|c|c|c|c|c|c|c|}
\hline Pu253 & 0.95 & 78.59 & 258.81 & 0.29 & 2.1 & 6.20 & 200 & 2.9 & 4.8 & $\mathrm{ND}<1$ & & 13.2 & $2.7 \mathrm{E}+01$ & & $1.6 \mathrm{E}-05$ & $2.6 \mathrm{E}-05$ & $8.7 \mathrm{E}-06$ & $1.9 \mathrm{E}-05$ & & & $1.7 \mathrm{E}-05$ & $1.0 \mathrm{E}-02$ & \\
\hline Pu254 & 0.95 & 79.13 & $\begin{array}{l}268.81 \\
266.85\end{array}$ & 0.29 & 2.1 & 5.35 & 19.0 & $\mathrm{ND}<1$ & 4.5 & $\mathrm{ND}<1$ & & 14.4 & $2.7 E+01$ & & $1.4 \mathrm{E}-05$ & $2.5 \mathrm{E}-05$ & & $1.8 \mathrm{E}-05$ & & & $1.8 \mathrm{E}-05$ & $1.0 \mathrm{E}-02$ & \\
\hline Pu255 & 0.95 & 78.77 & 271.86 & 0.29 & 2.0 & 6.25 & 20.0 & 7.2 & 4.9 & $\mathrm{ND}<1$ & 66.3 & 12.6 & $2.4 \mathrm{E}+01$ & & $1.6 \mathrm{E}-05$ & $2.6 \mathrm{E}-05$ & $2.2 \mathrm{E}-05$ & $1.9 \mathrm{E}-05$ & & $2.5 \mathrm{E}-04$ & $1.6 \mathrm{E}-05$ & $9.3 \mathrm{E}-03$ & \\
\hline Pu256 & 0.95 & 79.67 & 279.84 & 0.29 & 2.0 & 4.22 & 16.0 & 3.2 & 3.4 & $N D<1$ & 12.8 & 9.1 & $1.8 \mathrm{E}+01$ & & $1.1 \mathrm{E}-05$ & $2.1 E-05$ & $9.8 \mathrm{E}-06$ & $1.4 \mathrm{E}-05$ & & $5.0 \mathrm{E}-05$ & $1.2 \mathrm{E}-05$ & $6.9 \mathrm{E}-03$ & \\
\hline $\begin{array}{l}\text { Pu257 } \\
\text { Pu250 }\end{array}$ & 0.95 & 79.57 & $\begin{array}{r}286.90 \\
20.95\end{array}$ & 0.29 & 2.0 & $\begin{array}{r}4.60 \\
5.20\end{array}$ & 17.0 & 3.8 & 3.4 & $N D<1$ & 19.2 & 9.3 & $2.0 E+01$ & & 1.2E- -05 & 2.2E- -05 & 1.2E-05 & 1.4E-05 & & 7.4E-05 & $1.2 \mathrm{E}-05$ & $8.0 \mathrm{E}-03$ & \\
\hline Pu258 & 0.95 & 80.63 & 296.85 & 0.29 & 2.1 & 5.32 & 16.0 & 4.3 & 3.3 & $N D<1$ & 21.6 & 9.7 & $3.3 \mathrm{E}+01$ & & $1.4 \mathrm{E}-05$ & 2.1E-05 & $1.3 \mathrm{E}-05$ & $1.3 \mathrm{E}-05$ & & $8.5 \mathrm{E}-05$ & $1.3 \mathrm{E}-05$ & $1.3 \mathrm{E}-02$ & \\
\hline Pu259 & 0.95 & 80.94 & 299.85 & 0.29 & 2.1 & 4.69 & 18.0 & 5.3 & 4.1 & $N D<1$ & 43.3 & 12.7 & $3.6 \mathrm{E}+01$ & & $1.2 \mathrm{E}-05$ & $2.4 \mathrm{E}-05$ & $1.6 \mathrm{E}-05$ & $1.7 \mathrm{E}-05$ & & $1.7 \mathrm{E}-04$ & $1.6 \mathrm{E}-05$ & 1.4E-02 & \\
\hline Pu260 & 0.95 & 81.59 & 315.80 & 0.29 & 2.2 & 3.88 & 15.0 & 3.2 & 2.8 & $\mathrm{ND}<1$ & & 8.0 & 2.2E+01 & & $1.0 \mathrm{E}-05$ & $2.0 E-05$ & $1.0 \mathrm{E}-05$ & $1.2 \mathrm{E}-05$ & & & $1.0 \mathrm{E}-05$ & $8.7 \mathrm{E}-03$ & \\
\hline Pu261 & 0.95 & 82.76 & 323.90 & 0.29 & 2.2 & 3.64 & 14.0 & 3.1 & 2.7 & $\mathrm{ND}<1$ & 15.0 & 7.2 & $2.7 E+01$ & & $9.9 \mathrm{E}-06$ & $1.9 \mathrm{E}-05$ & $9.9 \mathrm{E}-06$ & $1.1 \mathrm{E}-05$ & & $6.1 \mathrm{E}-05$ & $9.6 \mathrm{E}-06$ & 1.11E-02 & \\
\hline Pu262 & 0.95 & 83.86 & 335.89 & 0.29 & 2.3 & 3.33 & 14.0 & 3.1 & 2.7 & $\mathrm{ND}<1$ & 15.4 & 7.5 & $2.7 E+01$ & & $9.2 \mathrm{E}-06$ & $2.0 \mathrm{E}-05$ & $1.0 \mathrm{E}-05$ & $1.1 \mathrm{E}-05$ & & $6.3 \mathrm{E}-05$ & $1.0 \mathrm{E}-05$ & $1.1 \mathrm{E}-02$ & \\
\hline Pu263 & 0.95 & 83.68 & 341.89 & 0.29 & 2.2 & 3.42 & 14.0 & 3.1 & 2.5 & $N D<1$ & 9.5 & 6.3 & $2.4 \mathrm{E}+01$ & & $9.4 \mathrm{E}-06$ & $1.9 \mathrm{E}-05$ & $1.0 \mathrm{E}-05$ & $1.1 \mathrm{E}-05$ & & $3.9 \mathrm{E}-05$ & $8.5 \mathrm{E}-06$ & $9.9 E-03$ & \\
\hline Pu264 & 0.94 & 79.60 & 350.87 & 0.29 & 2.2 & 3.37 & 14.0 & 3.1 & 2.5 & $N D<1$ & 6.9 & 7.6 & $2.0 E+01$ & & $8.8 \mathrm{E}-06$ & $1.9 \mathrm{E}-05$ & $9.5 \mathrm{E}-06$ & $1.0 \mathrm{E}-05$ & & 2.7E-05 & $9.7 E-06$ & $7.8 \mathrm{E}-03$ & \\
\hline Pu265 & 0.94 & 86.60 & 355.90 & 0.29 & 2.1 & 3.00 & 13.0 & 2.7 & 2.2 & $N D<1$ & 7.2 & 6.0 & $1.9 E+01$ & & $8.6 \mathrm{E}-06$ & $1.9 \mathrm{E}-05$ & $9.0 \mathrm{E}-06$ & $9.6 \mathrm{E}-06$ & & $3.0 \mathrm{E}-05$ & $8.4 \mathrm{E}-06$ & $8.0 \mathrm{E}-03$ & \\
\hline Pu266 & 0.94 & 93.19 & 363.85 & 0.29 & 2.2 & 2.98 & 12.0 & 2.7 & 2.0 & $N D<1$ & 9.7 & 5.6 & $2.2 E+01$ & & $9.2 \mathrm{E}-06$ & $1.9 \mathrm{E}-05$ & $9.7 \mathrm{E}-06$ & $9.4 \mathrm{E}-06$ & & $4.4 \mathrm{E}-05$ & $8.4 \mathrm{E}-06$ & $\begin{array}{l}1.0 \mathrm{E}-02 \\
\text {. }\end{array}$ & \\
\hline Pu267 & 0.94 & 60.61 & 377.80 & 0.29 & 2.3 & 4.69 & 17.0 & 4.2 & 3.7 & $N D<1$ & 23.9 & 10.6 & 2.4E+01 & & $9.4 \mathrm{E}-06$ & $1.7 \mathrm{E}-05$ & $9.8 \mathrm{E}-06$ & $1.1 \mathrm{E}-05$ & & 7.1E-05 & $1.0 \mathrm{E}-05$ & $7.0 \mathrm{E}-03$ & \\
\hline Pu268 & 0.94 & 61.11 & 385.88 & 0.29 & 2.3 & 4.56 & 16.0 & 4.0 & 3.4 & $N D<1$ & 15.5 & 9.3 & 3.2E +01 & & $9.2 \mathrm{E}-06$ & $1.6 \mathrm{E}-05$ & $9.4 \mathrm{E}-06$ & $1.1 \mathrm{E}-05$ & & $4.6 \mathrm{E}-05$ & $9.2 \mathrm{E}-06$ & $9.5 \mathrm{E}-03$ & \\
\hline Pu269 & 0.94 & 59.67 & 390.88 & 0.29 & 2.2 & 4.19 & 15.0 & 3.8 & 2.9 & $\mathrm{ND}<1$ & 25.8 & 8.6 & $2.3 E+01$ & & $8.3 \mathrm{E}-06$ & $1.5 \mathrm{E}-05$ & $8.7 \mathrm{E}-06$ & $8.8 \mathrm{E}-06$ & & $7.5 \mathrm{E}-05$ & $8.3 \mathrm{E}-06$ & $6.9 \mathrm{E}-03$ & \\
\hline Pu270 & 0.94 & 59.62 & 399.86 & 0.29 & 2.3 & 4.28 & 15.0 & 3.6 & 3.0 & $N D<1$ & 64.2 & 8.2 & $5.5 E+01$ & & $8.4 \mathrm{E}-06$ & $1.5 \mathrm{E}-05$ & $8.3 \mathrm{E}-06$ & $9.1 \mathrm{E}-06$ & & $1.9 \mathrm{E}-04$ & $7.9 \mathrm{E}-06$ & $1.6 \mathrm{E}-02$ & \\
\hline $\begin{array}{l}\text { Pu271 } \\
\end{array}$ & 0.94 & $\begin{array}{l}59.14 \\
5.05\end{array}$ & 405.87 & 0.29 & 2.2 & 4.31 & 15.0 & 3.6 & 3.0 & 1.9 & 12.4 & 7.7 & $2.5 E+01$ & & $\begin{array}{l}8.4 \mathrm{E}-06 \\
72 \mathrm{C}\end{array}$ & $\begin{array}{l}1.5 E-05 \\
14-05\end{array}$ & $8.2 \mathrm{E}-06$ & $\begin{array}{l}9.0 \mathrm{E}-06 \\
7 \mathrm{~F}-06\end{array}$ & $3.9 \mathrm{E}-04$ & 3.6E-05 & $\begin{array}{l}7.3 \mathrm{E}-06 \\
6\end{array}$ & $\begin{array}{l}7.4 E-03 \\
8\end{array}$ & \\
\hline $\begin{array}{l}\text { Pu272 } \\
\end{array}$ & 0.94 & $\begin{array}{l}58.95 \\
5857\end{array}$ & $\begin{array}{r}419.89 \\
\end{array}$ & 0.29 & 2.2 & $\begin{array}{l}3.67 \\
3.68\end{array}$ & $\begin{array}{l}14.0 \\
140\end{array}$ & $\begin{array}{l}3.1 \\
3.1\end{array}$ & 2.6 & $N D<1$ & $\begin{array}{l}25.6 \\
343\end{array}$ & 7.3 & $\begin{array}{l}2.8 \mathrm{E}+01 \\
42 \mathrm{P}+01\end{array}$ & & $\begin{array}{l}7.2 E-06 \\
71 \text { - }\end{array}$ & $\begin{array}{l}1.4 E-05 \\
14-0.55\end{array}$ & $\begin{array}{l}7.1 \mathrm{E}-06 \\
7.0 \mathrm{E}-6\end{array}$ & $\begin{array}{l}7.8 \mathrm{E}-06 \\
80 \mathrm{~F}-06\end{array}$ & & $\begin{array}{l}7.4 \mathrm{E}-05 \\
0\end{array}$ & $\begin{array}{l}6.9 \mathrm{E}-06 \\
65 \mathrm{~F}-06\end{array}$ & $\begin{array}{l}8.2 E-03 \\
12 E-02\end{array}$ & \\
\hline $\begin{array}{l}\text { Pu273 } \\
\text { Pu274 }\end{array}$ & $\begin{array}{l}0.94 \\
0.94\end{array}$ & $\begin{array}{l}58.57 \\
58.79\end{array}$ & $\begin{array}{l}433.94 \\
447.89\end{array}$ & $\begin{array}{l}0.29 \\
0.29\end{array}$ & $\begin{array}{l}2.3 \\
2.2\end{array}$ & $\begin{array}{l}3.68 \\
3.64\end{array}$ & $\begin{array}{l}14.0 \\
13.0\end{array}$ & $\begin{array}{l}3.1 \\
2.9\end{array}$ & $\begin{array}{l}2.7 \\
2.3\end{array}$ & $\begin{array}{l}\mathrm{ND}<1 \\
\mathrm{ND}<1\end{array}$ & $\begin{array}{l}34.3 \\
19.0\end{array}$ & 6.9 & $\begin{array}{l}4.2 E+01 \\
56 E+01\end{array}$ & & $\begin{array}{l}7.1 \mathrm{E}-06 \\
771-06\end{array}$ & $\begin{array}{r}1.4 \mathrm{E}-05 \\
1.3-0.5\end{array}$ & $\begin{array}{l}\text { 7.0E-06 } \\
66 \mathrm{E}-06\end{array}$ & $\begin{array}{l}8.0 \mathrm{E}-06 \\
6.9 \mathrm{E}-06\end{array}$ & & $\begin{array}{r}9.9 \mathrm{E}-05 \\
5.5 \mathrm{E}-05\end{array}$ & $\begin{array}{l}6.5 \mathrm{E}-06 \\
6.0 \mathrm{E}-06\end{array}$ & $\begin{array}{l}1.2 \mathrm{~L}-02 \\
1\end{array}$ & \\
\hline $\begin{array}{l}\text { Pun274 } \\
\text { Pu275 }\end{array}$ & $\begin{array}{l}0.94 \\
0.94\end{array}$ & $\begin{array}{l}58.79 \\
59.32\end{array}$ & $\begin{array}{l}447.89 \\
460.90\end{array}$ & $\begin{array}{l}0.29 \\
0.29\end{array}$ & $\begin{array}{l}2.2 \\
2.4\end{array}$ & $\begin{array}{l}3.64 \\
3.19\end{array}$ & $\begin{array}{l}13.0 \\
13.0\end{array}$ & $\begin{array}{l}2.9 \\
2.9\end{array}$ & $\begin{array}{l}2.3 \\
2.5\end{array}$ & $\begin{array}{l}\mathrm{NDD}<1 \\
\mathrm{ND}<1\end{array}$ & $\begin{array}{l}19.0 \\
32.3\end{array}$ & $\begin{array}{l}6.3 \\
7.3\end{array}$ & $\begin{array}{l}\begin{array}{l}5.6 \mathrm{E}+01 \\
3.5 \mathrm{E}+01\end{array}\end{array}$ & & 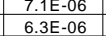 & $\begin{array}{r}.3 \mathrm{~B}-05 \\
1.3 \mathrm{E}-05\end{array}$ & $\begin{array}{l}6.6 \mathrm{E}-06 \\
6.6 \mathrm{E}-06\end{array}$ & $\begin{array}{l}6.9 \mathrm{E}-06 \\
7.5 \mathrm{E}-06\end{array}$ & & $\begin{array}{l}5.5 \mathrm{E}-05 \\
9.4 \mathrm{E}-05\end{array}$ & $\begin{array}{l}6.0 \mathrm{E}-06 \\
7.0 \mathrm{E}-06\end{array}$ & $\begin{array}{r}1.6 E-022 \\
1.0 E-02\end{array}$ & \\
\hline Pu276 & 0.94 & 58.98 & 477.89 & 0.29 & 2.2 & 3.47 & 13.0 & 2.9 & 2.4 & $\mathrm{ND}<1$ & 19.4 & 6.2 & 1.8E+01 & & $\begin{array}{l}6.8 \mathrm{E}-06 \\
6.86\end{array}$ & $\begin{array}{l}1.3 \mathrm{E}-\mathrm{U} \\
1.3 \mathrm{E}-05\end{array}$ & $\begin{array}{l}.6 \mathrm{E}-00 \\
6.6 \mathrm{E}-06\end{array}$ & $\begin{array}{l}1.5 \mathrm{E}-06 \\
7.2 \mathrm{E}-06\end{array}$ & & $\begin{array}{l}9.4 \mathrm{E}-05 \\
5.6 \mathrm{E}-05\end{array}$ & $\begin{array}{l}.0 \mathrm{E}-06 \\
5.9 \mathrm{E}-06\end{array}$ & $\begin{array}{l}1.0 E-02 \\
5.4 E-03\end{array}$ & \\
\hline & 0.94 & 58.58 & 485.90 & 0.29 & 2.0 & 3.39 & & & & & & & & & & & & & & & & & \\
\hline Pu278 & 0.94 & 53.97 & 503.38 & 0.29 & 2.2 & 2.77 & & & & & & & & & $5.0 \mathrm{E}-06$ & & & & & & & & \\
\hline Pu279 & 0.94 & 89.69 & 511.38 & 0.29 & 2.0 & 2.63 & & & & & & & & & $7.8 \mathrm{E}-06$ & & & & & & & & \\
\hline Pu280 & 0.94 & 40.74 & 531.48 & 0.29 & 2.1 & 4.79 & & & & & & & & & $6.5 \mathrm{E}-06$ & & & & & & & & \\
\hline Pu281 & 0.94 & 41.73 & 553.39 & 0.29 & 2.2 & 4.58 & & & & & & & & & $6.3 \mathrm{E}-06$ & & & & & & & & \\
\hline Pu282 & 0.93 & 39.11 & 575.38 & 0.29 & 2.3 & 4.13 & & & & & & & & & $5.4 \mathrm{E}-06$ & & & & & & & & \\
\hline Pu283 & 0.93 & 36.33 & 602.40 & 0.29 & 2.0 & 4.02 & & & & & & & & & $4.9 \mathrm{E}-06$ & & & & & & & & \\
\hline Pu284 & 0.93 & 39.06 & 624.41 & 0.29 & 2.4 & 3.61 & & & & & & & & & $4.7 E-06$ & & & & & & & & \\
\hline Pu285 & 0.93 & 47.97 & 657.34 & 0.29 & 2.3 & 2.92 & & & & & & & & & 4.7E- 06 & & & & & & & & \\
\hline $25 \mathrm{C}$ data & Mass & Flow Rate & Run time & SurfArea & $\mathrm{pH}$ & $\mathrm{Pu}$ & u & $\mathrm{Hf}$ & $\mathrm{Gd}$ & $\mathrm{Ga}$ & $\mathrm{Ca}$ & $\mathrm{Ti}_{\mathrm{i}}$ & $2 n$ & $\mathrm{Mg}$ & NR-Pu(PH4) & $\mathrm{NR}-\mathrm{U}(\mathrm{pH} 4)$ & NR-Hf & NR-Gd(pH4) & NR-Ga & $\mathrm{NR}-\mathrm{Ca}$ & NR-Ti & NR-Zn & NR-Mg \\
\hline $\mathrm{pH} 4$ & (g) & (mL/day) & (days) & (sq. m) & & $\mathrm{ppb}$ & ppb & $\mathrm{ppb}$ & $\mathrm{ppb}$ & $\mathrm{ppb}$ & $\mathrm{ppb}$ & $\mathrm{ppb}$ & ppb & $\mathrm{ppb}$ & $\mathrm{g} / \mathrm{m}^{\wedge} 2 / \mathrm{da}$ & $\mathrm{g} / \mathrm{m}^{2} 2 / \mathrm{day}$ & $\mathrm{g} / \mathrm{m}^{\wedge} 2 / \mathrm{da}$ & $\mathrm{g} / \mathrm{m}^{\wedge} / \mathrm{day}$ & $\mathrm{g} / \mathrm{m}^{\wedge} 2 / \mathrm{day}$ & $\mathrm{g} / \mathrm{m}^{\wedge} 2 / \mathrm{day}$ & $\mathrm{g} / \mathrm{m}^{\wedge} 2 / \mathrm{da}$ & $\mathrm{g} / \mathrm{m}^{\wedge} 2 / \mathrm{da}$ & $\mathrm{g} / \mathrm{m}^{\wedge} 2 / \mathrm{day}$ \\
\hline $\begin{array}{l}\text { start } \\
\text { Punt01 }\end{array}$ & $\begin{array}{l}1.00 \\
1.00\end{array}$ & 15.40 & 0.35 & $\begin{array}{l}0.30 \\
0.30\end{array}$ & $\begin{array}{l}4.1 \\
4.3\end{array}$ & 58 & & & & & & & & & 298 & & & & & & & & \\
\hline $\begin{array}{l}\text { Pu401 } \\
\text { Pu402 }\end{array}$ & $\begin{array}{l}1.00 \\
1.00\end{array}$ & $\begin{array}{l}15.40 \\
15.37\end{array}$ & $\begin{array}{l}0.35 \\
1.20\end{array}$ & $\begin{array}{l}0.30 \\
0.30\end{array}$ & $\begin{array}{l}4.3 \\
4.3\end{array}$ & $\begin{array}{l}58.9 \\
26.7\end{array}$ & 758.0 & 3.5 & 881.0 & & & 14.0 & & & $\begin{array}{l}2.9 \mathrm{E}-05 \\
1.3 \mathrm{E}-05\end{array}$ & $1.9 \mathrm{E}-04$ & $2.0 \mathrm{E}-06$ & $6.6 \mathrm{E}-04$ & & & $3.3 \mathrm{E}-06$ & & \\
\hline Pu403 & 1.00 & 15.25 & 2.40 & 0.30 & 4.3 & 18.5 & 259.0 & $\begin{array}{l}3.5 \\
2.2\end{array}$ & 613.0 & & & $\begin{array}{l}15.0 \\
15.0\end{array}$ & & & $\begin{array}{l}9.0 E-06 \\
9.0 E-06\end{array}$ & $\begin{array}{l}. .35-04 \\
6.3 E-05\end{array}$ & $\begin{array}{l}.0 \mathrm{E}-06 \\
1.2 \mathrm{E}-06\end{array}$ & $\begin{array}{l}0.0 \mathrm{E}-04 \\
4.5 \mathrm{E}-04\end{array}$ & & & $3.5 \mathrm{E}-06$ & & \\
\hline Pu404 & 1.00 & 15.43 & 3.01 & 0.30 & 4.2 & 16.3 & & & & & & & & & $8.0 E-06$ & & & & & & & & \\
\hline Pu405 & 1.00 & 15.23 & 5.84 & 0.30 & 4.1 & 12.4 & & & & & & & & & $6.0 \mathrm{E}-06$ & & & & & & & & \\
\hline Pu406 & 1.00 & 15.26 & 7.87 & 0.30 & 4.1 & 11.4 & & & & & & & & & $5.5 \mathrm{E}-06$ & & & & & & & & \\
\hline Pu407 & 1.00 & 15.44 & 9.88 & 0.30 & 4.1 & 10.9 & & & & & & & & & $5.4 \mathrm{E}-06$ & & & & & & & & \\
\hline Pu408 & 1.00 & 15.54 & 12.90 & 0.30 & 4.1 & 10.6 & & & & & & & & & $5.2 \mathrm{E}-06$ & & & & & & & & \\
\hline $\begin{array}{l}\text { Pu409 } \\
\text { Put10 }\end{array}$ & 1.00 & $\begin{array}{r}15.60 \\
15.56\end{array}$ & $\begin{array}{l}15.88 \\
10.89\end{array}$ & 0.30 & 4.0 & 10.7 & & & & & & & & & & & & & & & & & \\
\hline $\begin{array}{l}\text { Pu410 } \\
\text { Put11 }\end{array}$ & 1.00 & $\begin{array}{r}15.56 \\
15.53\end{array}$ & $\begin{array}{l}19.88 \\
2286\end{array}$ & 0.30 & 4.0 & $\begin{array}{l}11.0 \\
109\end{array}$ & & & & & & & & & $\begin{array}{l}5.4 E-06 \\
5.4 E-06\end{array}$ & & & & & & & & \\
\hline $\begin{array}{l}\text { Pu411 } \\
\text { Put12 }\end{array}$ & 1.00 & $\begin{array}{r}15.53 \\
1564\end{array}$ & $\begin{array}{l}22.86 \\
2686\end{array}$ & $\begin{array}{l}0.30 \\
0.30\end{array}$ & $\begin{array}{l}4.0 \\
40\end{array}$ & $\begin{array}{l}10.9 \\
112\end{array}$ & & & & & & & & & $\begin{array}{l}5.4 \mathrm{E}-06 \\
55 \mathrm{5}-06\end{array}$ & & & & & & & & \\
\hline $\begin{array}{l}\text { Put412 } \\
\text { Pu413 }\end{array}$ & $\begin{array}{l}1.00 \\
1.00\end{array}$ & $\begin{array}{l}\begin{array}{l}15.64 \\
15.60\end{array}\end{array}$ & $\begin{array}{l}26.86 \\
29.89\end{array}$ & $\begin{array}{l}0.30 \\
0.30\end{array}$ & $\begin{array}{l}4.0 \\
4.0\end{array}$ & $\begin{array}{l}11.2 \\
11.6\end{array}$ & 95.0 & 1.5 & 795.0 & & & 52.0 & & & $\begin{array}{l}5.5 \mathrm{E}-06 \\
5.8 \mathrm{E}-06\end{array}$ & $2.4 \mathrm{E}-05$ & $8.7 \mathrm{E}-07$ & $6.0 \mathrm{E}-04$ & & & $1.3 \mathrm{E}-05$ & & \\
\hline Pu414 & 1.00 & 15.87 & 37.91 & 0.30 & 4.0 & 10.5 & & & & & & & & & $5.3 \mathrm{E}-06$ & & & & & & & & \\
\hline Pu415 & 1.00 & 31.40 & 48.88 & 0.30 & 4.0 & 9.4 & & & & & & & & & & & & & & & & & \\
\hline $\begin{array}{l}\text { Pu416 } \\
\text { Put17 }\end{array}$ & 1.00 & 31.36 & $\begin{array}{l}51.83 \\
55\end{array}$ & 0.30 & 3.9 & 9.1 & 36.0 & 0.6 & 117.0 & & & 32.0 & & & $\begin{array}{l}9.1 E-06 \\
9.95-26\end{array}$ & $1.8 \mathrm{E}-05$ & $7.0 \mathrm{E}-07$ & $1.8 \mathrm{E}-04$ & & & $1.6 \mathrm{E}-05$ & & \\
\hline $\begin{array}{l}\text { Pu4417 } \\
\text { Put18 }\end{array}$ & $\begin{array}{l}1.00 \\
1.00\end{array}$ & $\begin{array}{l}31.32 \\
31.42\end{array}$ & $\begin{array}{l}55.90 \\
58.83\end{array}$ & $\begin{array}{l}0.30 \\
0.30\end{array}$ & 3.9 & $\begin{array}{l}9.5 \\
9.5\end{array}$ & 38.0 & 0.7 & 680 & & & & & & $\begin{array}{l}9.5 \mathrm{E}-06 \\
995-06\end{array}$ & $19=05$ & $82 \mathrm{E}-07$ & - OE-04 & & & $18 \mathrm{E}-05$ & & \\
\hline $\begin{array}{l}\text { Put18 } \\
\text { Pu419 }\end{array}$ & $\begin{array}{l}1.00 \\
1.00\end{array}$ & $\begin{array}{l}31.42 \\
31.62\end{array}$ & $\begin{array}{l}58.83 \\
62.39\end{array}$ & $\begin{array}{l}0.30 \\
0.30\end{array}$ & $\begin{array}{l}3.9 \\
4.1\end{array}$ & $\begin{array}{l}9.5 \\
9.6\end{array}$ & $\begin{array}{l}38.0 \\
31.0\end{array}$ & $\begin{array}{l}0.7 \\
0.7\end{array}$ & $\begin{array}{l}68.0 \\
4.0\end{array}$ & & & $\begin{array}{l}37.0 \\
31.0\end{array}$ & & & $\begin{array}{l}9.55-06 \\
9.6 E-06\end{array}$ & $\begin{array}{l}1.9 \mathrm{E}-5-5 \\
1.6 \mathrm{E}-05\end{array}$ & $\begin{array}{l}8.2 \mathrm{E}-07 \\
8.2 \mathrm{E}-07\end{array}$ & $\begin{array}{l}1.0 \mathrm{E}-04 \\
6.2 \mathrm{E}-05\end{array}$ & & & $\begin{array}{l}1.8 \mathrm{E}-05 \\
1.5 \mathrm{E}-05\end{array}$ & & \\
\hline Pu420 & 1.00 & 31.46 & 65.82 & 0.30 & 3.9 & 10.1 & & & & & & & & & $\begin{array}{l}. .05-00 \\
1.0 E-05\end{array}$ & & & & & & & & \\
\hline Pu421 & 1.00 & 31.41 & 69.86 & 0.30 & 4.0 & 9.4 & 26.0 & 0.7 & 23.0 & & & 26.0 & & & $9.3 \mathrm{E}-06$ & $1.3 \mathrm{E}-05$ & $8.2 \mathrm{E}-07$ & $3.5 \mathrm{E}-05$ & & & $1.3 \mathrm{E}-05$ & & \\
\hline Pu422 & 1.00 & & & & 3.9 & 9.4 & & & & & & & & & & & & & & & & & \\
\hline $\begin{array}{l}\text { Pu423 } \\
\end{array}$ & 1.00 & $\begin{array}{r}35.95 \\
3.494\end{array}$ & $\begin{array}{l}76.89 \\
8396\end{array}$ & 0.30 & 4.0 & 8.2 & 20.0 & 0.7 & 13.0 & & & 22.0 & & & $\begin{array}{l}9.3 E-06 \\
925-2\end{array}$ & $1.2 E-05$ & $9.4 \mathrm{E}-07$ & $2.3 \mathrm{E}-05$ & & & $1.2 \mathrm{E}-05$ & & \\
\hline $\begin{array}{l}\text { Put24 } \\
\text { Put25 }\end{array}$ & $\begin{array}{l}1.00 \\
1.00\end{array}$ & $\begin{array}{l}34.94 \\
34.74\end{array}$ & $\begin{array}{l}83.86 \\
86.87\end{array}$ & $\begin{array}{l}0.30 \\
0.30\end{array}$ & $\begin{array}{l}4.0 \\
3.9\end{array}$ & $\begin{array}{l}8.2 \\
8.0\end{array}$ & 22.0 & 1.0 & 12.0 & & & 23.0 & & & $\begin{array}{l}9.2 \mathrm{E}-06 \\
8.8 \mathrm{E}-06\end{array}$ & $1.2 E-05$ & $1.3 \mathrm{E}-06$ & $2.0 \mathrm{E}-05$ & & & $12 E-05$ & & \\
\hline $\begin{array}{l}\text { Punt25 } \\
\text { Pu426 }\end{array}$ & 1.00 & $\begin{array}{l}34.1 / 4 \\
31.66\end{array}$ & 90.94 & $\begin{array}{l}0.30 \\
0.30\end{array}$ & $\begin{array}{l}3.9 \\
3.9\end{array}$ & 8.7 & & & 12.0 & & & 23.0 & & & $\begin{array}{l}8.8-06-06 \\
8.7 E-06\end{array}$ & $1.2 \mathrm{E}-05$ & $1.3 \mathrm{E}-06$ & $2.0 \mathrm{E}-05$ & & & $1.2 \mathrm{E}-05$ & & \\
\hline Pu427 & 0.99 & 31. & & 0. & 3.9 & 8.3 & 20.0 & 1.1 & 11.0 & & & 21.0 & & & $8.3 \mathrm{E}-06$ & $1.0 E-05$ & $1.3 \mathrm{E}-06$ & 1.7E-05 & & & $1.0 \mathrm{E}-05$ & & \\
\hline Pu428 & 0.99 & & & & 4.0 & 27 & & & & & & & & & & & & & & & & & \\
\hline Pu429 & 0.99 & 8. & 105.01 & 0.3 & 3.9 & 25.8 & 61.0 & 5.9 & 28.0 & & & 50.0 & & & 7.3 & $8.7 E-06$ & $1.9 \mathrm{E}-06$ & $1.2 \mathrm{E}-05$ & & & $6.9 \mathrm{E}-06$ & & \\
\hline $\begin{array}{l}\text { Pu430 } \\
\text { Put31 }\end{array}$ & 0.99 & $\begin{array}{r}8.86 \\
88.55\end{array}$ & $\begin{array}{l}113.04 \\
111091\end{array}$ & 0.30 & 3.9 & 23.7 & 50.0 & 6.1 & 23.0 & 8.1 & $\begin{array}{l}76.4 \\
31.4\end{array}$ & 45.5 & $\begin{array}{l}2.7 E+01 \\
3\end{array}$ & $5.8 \mathrm{E}+00$ & $\begin{array}{l}6.7 E-06 \\
7\end{array}$ & $\begin{array}{l}7.1 E-06 \\
117-05\end{array}$ & 2.0E-06 & 1.0E-05 & 2.4E- 04 & 3.2E-05 & $6.3 \mathrm{E}-06$ & 1.11E-03 & 1.7E-03 \\
\hline $\begin{array}{l}\text { Pu431 } \\
\text { Pus32 }\end{array}$ & 0.99 & $\begin{array}{l}48.45 \\
48.19\end{array}$ & $\begin{array}{l}119.91 \\
125.39\end{array}$ & $\begin{array}{l}0.30 \\
0.30\end{array}$ & 4.0 & $\begin{array}{l}4.8 \\
4.5\end{array}$ & $\begin{array}{l}22.0 \\
10.0\end{array}$ & $\begin{array}{l}2.6 \\
1.2\end{array}$ & $\begin{array}{l}20.0 \\
4.3\end{array}$ & $\begin{array}{l}5.6 \\
1.3\end{array}$ & $\begin{array}{l}31.4 \\
113\end{array}$ & $\begin{array}{l}24.0 \\
118\end{array}$ & $\begin{array}{l}3.3 \mathrm{E}+01 \\
80-0.1\end{array}$ & $\begin{array}{l}5.1 E+00 \\
1.1 E+5+0\end{array}$ & $\begin{array}{l}7.4 \mathrm{E}-06 \\
6.9 E-06\end{array}$ & $\begin{array}{r}1.7 \mathrm{E}-05 \\
78 \mathrm{E}-0 .\end{array}$ & $\begin{array}{l}\text { 4.7E-06 } \\
22 \mathrm{E}-06\end{array}$ & $\begin{array}{l}4.7 \mathrm{E}-05 \\
1 . \mathrm{E}-05\end{array}$ & $\begin{array}{l}9.1 E-04 \\
2.1 E-04\end{array}$ & $\begin{array}{l}7.2 \mathrm{E}-05 \\
26 \mathrm{E}-05\end{array}$ & $\begin{array}{l}1.8 \mathrm{E}-05 \\
\end{array}$ & $\begin{array}{l}7.6 E-03 \\
1.6 E-04\end{array}$ & $\begin{array}{l}8.3 \mathrm{E}-03 \\
1\end{array}$ \\
\hline $\begin{array}{l}\text { Pu432 } \\
\text { Pu433 }\end{array}$ & $\begin{array}{l}0.99 \\
0.99\end{array}$ & 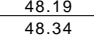 & $\begin{array}{l}125.39 \\
132.92\end{array}$ & $\begin{array}{l}0.30 \\
0.30\end{array}$ & $\begin{array}{l}4.0 \\
4.0\end{array}$ & $\begin{array}{l}4.5 \\
4.1\end{array}$ & $\begin{array}{l}10.0 \\
15.0\end{array}$ & $\begin{array}{l}1.2 \\
1.7\end{array}$ & $\begin{array}{l}4.3 \\
6.2\end{array}$ & $\begin{array}{l}1.3 \\
1.7\end{array}$ & $\begin{array}{l}11.3 \\
23.9\end{array}$ & $\begin{array}{l}11.8 \\
18.7\end{array}$ & $\begin{array}{l}8.0 \mathrm{E}-01 \\
3.5 \mathrm{E}+01\end{array}$ & $\begin{array}{l}1.0 E+00 \\
2.1 E+00\end{array}$ & $\begin{array}{l}6.9 \mathrm{E}-06 \\
6 \mathrm{~B}-06\end{array}$ & $\begin{array}{l}7.82-06 \\
1.2 E-05\end{array}$ & $\begin{array}{l}2.2 \mathrm{E}-06 \\
3.1 \mathrm{E}-6\end{array}$ & $\begin{array}{l}1.0 \mathrm{E}-05 \\
1.5 \mathrm{E}-05\end{array}$ & $\begin{array}{l}2.11-1-44 \\
28 E-04\end{array}$ & $\begin{array}{l}2.6 \mathrm{E}-05 \\
5.5 \mathrm{E}-05\end{array}$ & $\begin{array}{l}8.8 \mathrm{E}-06 \\
1.4 \mathrm{E}-05\end{array}$ & $\begin{array}{l}1.8 \mathrm{E}-04 \\
8\end{array}$ & $\begin{array}{l}1.6 \mathrm{E}-03 \\
3\end{array}$ \\
\hline $\begin{array}{l}\text { Put333 } \\
\text { Put34 }\end{array}$ & $\begin{array}{l}0.99 \\
0.99\end{array}$ & $\begin{array}{l}48.34 \\
48.29\end{array}$ & $\begin{array}{l}132.92 \\
139.88\end{array}$ & 0.3 & $\begin{array}{l}4.0 \\
4.0\end{array}$ & $\begin{array}{l}4.1 \\
4.1\end{array}$ & $\begin{array}{l}15.0 \\
8.9\end{array}$ & $\begin{array}{l}1.7 \\
1.2\end{array}$ & $\begin{array}{l}6.2 \\
3.4\end{array}$ & $\mathrm{ND}<1$ & $\begin{array}{l}3.9 \\
36.0\end{array}$ & $\begin{array}{l}18.1 \\
10.7\end{array}$ & $\begin{array}{l}3.5 \mathrm{E}+01 \\
3.4 \mathrm{E}+01\end{array}$ & $\begin{array}{l}2.1 E+00 \\
2.1 E+00\end{array}$ & & $\begin{array}{l}1.2 \\
6.9\end{array}$ & $\begin{array}{l}3.1 \\
2.2\end{array}$ & $\begin{array}{l}1.5 \\
8.0\end{array}$ & & & $\begin{array}{l}1.4 .4-05 \\
8.0 \mathrm{E}-06\end{array}$ & 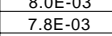 & 03 \\
\hline Pu435 & 0.99 & 48 & 146 & 0. & 4.0 & 4.1 & 8 & 1.3 & 3.1 & $N D<1$ & 20.1 & 10.6 & 3.6E+01 & 1.5 & & & & & & & & & \\
\hline Pu436 & 0.99 & 48. & 152 & 0.3 & 4.0 & 4.1 & 9.2 & 1.7 & 3.3 & 2. & 13 & 9.9 & 2.11 & $1.8 \mathrm{E}+00$ & & & & & 3.7E-04 & & & & \\
\hline Pu437 & 0.99 & 64.59 & 168 & 0.3 & 4.0 & 3.8 & 12.0 & 1.8 & 11.0 & $N D<1$ & 38.9 & 13.0 & $1.0 E+02$ & $5.1 \mathrm{E}+00$ & 7.8 & 1.2 & & & & $1.2 \mathrm{E}$ & $1.3 \mathrm{E}-05$ & $\begin{array}{l}3.1 \mathrm{~T}-02 \\
\text { 3. }\end{array}$ & $1.1 \mathrm{E}-02$ \\
\hline Pu438 & 0.99 & 64.1 & 174 & 0 & 4.0 & 3.1 & 7.4 & 1.3 & 2.5 & $\mathrm{ND}<1$ & 14.9 & 8.8 & $3.7 E+01$ & $1.9 \mathrm{E}$ & 6.4 & 7.7 & 3.1 & $7.9 \mathrm{E}-06$ & & $4.5 \mathrm{E}-05$ & $8.8 \mathrm{E}-06$ & $1.1 \mathrm{E}-02$ & $4.1 \mathrm{E}-03$ \\
\hline & 0. & & & & 3.9 & 3. & 6.6 & 1.1 & 2.0 & & & 7.6 & & & & & & & & & & & \\
\hline Pu440 & 0.99 & 65 & & 0 & 3.9 & 3.0 & 7.2 & 1.3 & 2.3 & $\mathrm{~N}$ & 15.7 & 8. & 2. & $1.3 \mathrm{C}$ & & & 3. & 7. & & 55 & 06 & $8.6 \mathrm{E}-03$ & $2.8 \mathrm{E}-03$ \\
\hline Pu441 & 0.99 & 66 & 19 & 0 & 3.9 & 2.9 & 6.4 & 1.2 & 1.9 & $\mathrm{~N}$ & 9.5 & 6.8 & 2.1 & 1.6 & 6. & 6.8 & 3.0 & 6 & & 55 & 06 & 03 & $3.5 \mathrm{E}-03$ \\
\hline $\begin{array}{l}\text { Pu442 } \\
\text { Pu443 }\end{array}$ & $\begin{array}{l}0.99 \\
0.99\end{array}$ & $\begin{array}{l}64.81 \\
65666\end{array}$ & $\begin{array}{l}202.88 \\
20988\end{array}$ & $\begin{array}{l}0.30 \\
0.30\end{array}$ & $\begin{array}{l}4.0 \\
3.9\end{array}$ & $\begin{array}{l}2.9 \\
2.9\end{array}$ & $\begin{array}{l}6.8 \\
5.8\end{array}$ & $\begin{array}{l}1.3 \\
1.1\end{array}$ & $\begin{array}{l}2.0 \\
1.7\end{array}$ & $\begin{array}{l}N D<1 \\
N D<1\end{array}$ & $\begin{array}{c}18.8 \\
8.0\end{array}$ & $\begin{array}{l}7.2 \\
6.5\end{array}$ & $\begin{array}{l}2.6 \mathrm{E}+01 \\
2.1 \mathrm{E}+01\end{array}$ & $\begin{array}{r}1.9 \mathrm{E}+00 \\
1.2 \mathrm{E}+00\end{array}$ & & $\begin{array}{l}7.11-06 \\
6611-06\end{array}$ & $\begin{array}{l}3.1 \mathrm{E}-06 \\
2.7 \mathrm{E}-06\end{array}$ & $\begin{array}{l}6.3 \mathrm{E}-06 \\
5.5 \mathrm{E}-06\end{array}$ & & $\begin{array}{l}5.8 \mathrm{E}-05 \\
25 \mathrm{E}-05\end{array}$ & $\begin{array}{l}7.3 \mathrm{E}-06 \\
6.7 \mathrm{E}-06\end{array}$ & $\begin{array}{l}8.2 E-03 \\
6.55-03\end{array}$ & $\begin{array}{l}4.1 \mathrm{E}-03 \\
26 \mathrm{E}-03\end{array}$ \\
\hline $\begin{array}{l}\text { Pu443 } \\
\text { Pu444 }\end{array}$ & 0.99 & $\begin{array}{l}65.66 \\
65.95\end{array}$ & $\begin{array}{l}209.88 \\
21.88\end{array}$ & $\begin{array}{l}0.30 \\
0.30\end{array}$ & $\begin{array}{l}3.9 \\
3.9\end{array}$ & $\begin{array}{l}2.9 \\
2.9\end{array}$ & $\begin{array}{l}5.8 \\
56\end{array}$ & $\begin{array}{l}1.1 \\
1.5\end{array}$ & 1.7 & $\begin{array}{l}N D<1 \\
N D<1\end{array}$ & $\begin{array}{l}8.0 \\
115\end{array}$ & $\begin{array}{l}6.5 \\
6.5\end{array}$ & $\begin{array}{l}2.1 \mathrm{E}+01 \\
23 \mathrm{E}+01\end{array}$ & $\begin{array}{r}1.2 \mathrm{E}+00 \\
4 \mathrm{E}+\mathrm{E}+00\end{array}$ & $\begin{array}{l}6.1 \mathrm{E}-06 \\
55 \mathrm{~F}-06\end{array}$ & $\begin{array}{l}6.11 E-06 \\
60-06\end{array}$ & $\begin{array}{l}2.7 \mathrm{E}-06 \\
3.7 \mathrm{E}-06\end{array}$ & $\begin{array}{l}5.5 \mathrm{E}-06 \\
5.2 \mathrm{E}-06\end{array}$ & & $\begin{array}{l}2.5 \mathrm{E}-05 \\
36 \mathrm{E}-05\end{array}$ & $\begin{array}{l}6.7 \mathrm{~F}-06 \\
65-5-06\end{array}$ & $\begin{array}{l}6.5 \mathrm{E}-03 \\
7.4 \mathrm{E}-03\end{array}$ & $\begin{array}{l}2.6 \mathrm{E}-03 \\
3 . \mathrm{E}-03\end{array}$ \\
\hline $\begin{array}{l}\text { Put444 } \\
\text { Pu445 }\end{array}$ & $\begin{array}{l}0.99 \\
0.99\end{array}$ & $\begin{array}{l}65.95 \\
65.70\end{array}$ & $\begin{array}{l}216.88 \\
223.89\end{array}$ & $\begin{array}{l}0.30 \\
0.30\end{array}$ & $\begin{array}{l}3.9 \\
4.0\end{array}$ & $\begin{array}{l}2.7 \\
2.7\end{array}$ & $\begin{array}{l}5.6 \\
5.9\end{array}$ & $\begin{array}{l}1.5 \\
1.1\end{array}$ & $\begin{array}{l}1.6 \\
1.6\end{array}$ & $\begin{array}{l}\mathrm{NDD}<1 \\
\mathrm{ND}<1\end{array}$ & $\begin{array}{l}11.5 \\
19.3\end{array}$ & $\begin{array}{l}6.3 \\
6.7\end{array}$ & $\begin{array}{l}2.3 \mathrm{~B}+01 \\
3.8 \mathrm{E}+01\end{array}$ & $\begin{array}{l}1.4 E+00 \\
3.7 E+00\end{array}$ & $5.6 \mathrm{E}-06$ & $6.3 \mathrm{E}-06$ & $2.7 \mathrm{E}-06$ & $5.2 \mathrm{E}-06$ & & $\begin{array}{l}3.6 \mathrm{E}-05 \\
6.0 \mathrm{E}-05\end{array}$ & $6.9 \mathrm{E}-06$ & $\begin{array}{l}7.4 \mathrm{E}-\mathrm{E}-3 \\
1.2 \mathrm{E}-02\end{array}$ & $\begin{array}{l}3.1 \mathrm{E}-03 \\
8.2 \mathrm{E}-03\end{array}$ \\
\hline
\end{tabular}

Page 39 
SPFT Data Table

\begin{tabular}{|c|c|c|c|c|c|c|c|c|c|c|c|c|c|c|c|c|c|c|c|c|c|c|c|}
\hline Pu446 & 0.99 & 66.46 & 237.83 & 0.30 & 4.0 & 2.9 & 6.0 & 1.6 & 1.5 & $\mathrm{ND}<1$ & & 4.1 & $5.7 E+01$ & & $6.1 \mathrm{E}-06$ & $6.4 \mathrm{E}-06$ & $4.0 \mathrm{E}-06$ & $4.9 \mathrm{E}-06$ & & & $4.3 \mathrm{E}-06$ & $1.8 \mathrm{E}-02$ & \\
\hline Pu447 & 0.99 & 80.74 & 244.84 & 0.30 & 4.0 & 2.4 & 4.7 & 1.3 & 1.3 & $\mathrm{ND}<1$ & & 4.8 & $6.3 \mathrm{E}+01$ & & $6.1 \mathrm{E}-06$ & $6.1 \mathrm{E}-06$ & $3.9 \mathrm{E}-06$ & $5.1 \mathrm{E}-06$ & & & $6.0 \mathrm{E}-06$ & $2.5 \mathrm{E}-02$ & \\
\hline Pu448 & 0.99 & 80.63 & 245.82 & 0.30 & 4.1 & 2.3 & 4.9 & 1.4 & 1.4 & $N D<1$ & & 4.6 & $4.8 \mathrm{E}+01$ & & $5.8 \mathrm{E}-06$ & $6.4 \mathrm{E}-06$ & $4.2 \mathrm{E}-06$ & $5.5 \mathrm{E}-06$ & & & $5.8 \mathrm{E}-06$ & $1.9 \mathrm{E}-02$ & \\
\hline Pu449 & 0.99 & 84.30 & 246.88 & 0.30 & 4.1 & 2.2 & 4.2 & 1.2 & 1.1 & $N D<1$ & & 4.1 & $4.2 \mathrm{E}+01$ & & $5.8 \mathrm{E}-06$ & $5.7 \mathrm{E}-06$ & $3.8 \mathrm{E}-06$ & $4.5 \mathrm{E}-06$ & & & $5.4 \mathrm{E}-06$ & $1.7 E-02$ & \\
\hline $\begin{array}{l}\text { Pu450 } \\
\text { Pu451 }\end{array}$ & $\begin{array}{l}0.99 \\
0.99\end{array}$ & $\begin{array}{l}85.04 \\
84.44\end{array}$ & $\begin{array}{l}247.86 \\
250.84\end{array}$ & $\begin{array}{l}0.30 \\
0.30\end{array}$ & $\begin{array}{l}4.1 \\
4.1\end{array}$ & $\begin{array}{l}2.1 \\
2.3\end{array}$ & $\begin{array}{l}4.6 \\
4.3\end{array}$ & $\begin{array}{l}1.2 \\
1.3\end{array}$ & $\begin{array}{l}1.2 \\
1.1\end{array}$ & $\begin{array}{l}N D<1 \\
N D<1\end{array}$ & & $\begin{array}{l}8.0 \\
3.5\end{array}$ & $\begin{array}{l}2.3 \mathrm{E}+01 \\
1.9 \mathrm{E}+01\end{array}$ & & $\begin{array}{l}5.7 \mathrm{EE}-06 \\
6.2 \mathrm{E}-06\end{array}$ & $\begin{array}{l}6.3 \mathrm{E}-06 \\
5.9 \mathrm{E}-06\end{array}$ & $\begin{array}{l}3.8 \mathrm{E}-06 \\
4.1 \mathrm{E}-06\end{array}$ & $\begin{array}{l}5.0 \mathrm{E}-06 \\
4.6 \mathrm{E}-06\end{array}$ & & & $\begin{array}{l}1.1 \mathrm{E}-05 \\
4.6 \mathrm{E}-06\end{array}$ & $\begin{array}{l}9.4 \mathrm{~A}-03 \\
7.7 \mathrm{E}-03\end{array}$ & \\
\hline $\begin{array}{l}\text { Pu451 } \\
\text { Pu452 }\end{array}$ & $\begin{array}{l}0.99 \\
0.99\end{array}$ & $\begin{array}{l}84.44 \\
84.22\end{array}$ & $\begin{array}{l}255.84 \\
254.80\end{array}$ & $\begin{array}{l}0.30 \\
0.30\end{array}$ & $\begin{array}{l}4.1 \\
4.1\end{array}$ & $\begin{array}{l}2.3 \\
2.3\end{array}$ & $\begin{array}{l}4.3 \\
4.4\end{array}$ & $\begin{array}{l}1.3 \\
1.1\end{array}$ & $\begin{array}{l}1.1 \\
1.1\end{array}$ & $\begin{array}{l}\mathrm{ND}<1 \\
\mathrm{ND}<1\end{array}$ & & $\begin{array}{l}3.5 \\
7.5\end{array}$ & $\begin{array}{l}1.9 E+01 \\
3.2 E+01\end{array}$ & & $\begin{array}{l}\begin{array}{l}6.2 \mathrm{E}-06 \\
6.3 \mathrm{E}-06\end{array} \\
6\end{array}$ & $\begin{array}{l}5.9 \mathrm{E}-06 \\
6.0 \mathrm{E}-06\end{array}$ & $\begin{array}{l}4.1 \mathrm{E}-06 \\
3.5 \mathrm{E}-06\end{array}$ & $\begin{array}{l}4.6 \mathrm{E}-06 \\
4.5 \mathrm{E}-06\end{array}$ & & & $\begin{array}{l}4.6 \mathrm{E}-06 \\
9.9 \mathrm{E}-06\end{array}$ & $\begin{array}{l}7.7 F-03 \\
1.3 E-02\end{array}$ & \\
\hline Pu453 & 0.99 & 86.06 & 258.81 & 0.30 & 4.1 & 2.7 & 5.4 & 1.6 & 1.3 & $N D<1$ & & 3.5 & $2.9 \mathrm{E}+01$ & & $7.4 \mathrm{E}-06$ & $7.5 \mathrm{E}-06$ & $\begin{array}{l}3.5 \mathrm{E}-06 \\
5.1 \mathrm{E}-06\end{array}$ & $\begin{array}{l}4.5 \mathrm{E}-06 \\
5.5 \mathrm{E}-06\end{array}$ & & & $\begin{array}{l}.9 \mathrm{E}-06 \\
4.7 \mathrm{E}-06\end{array}$ & $\begin{array}{l}1.1 \mathrm{EE}-22 \\
1.2 \mathrm{E}-02\end{array}$ & \\
\hline & 0.99 & 87.17 & 266.85 & 0.30 & 4.1 & 2.8 & & 1.1 & 1.0 & $N D<1$ & & 4.3 & $2.7 E+01$ & & $7.9 \mathrm{E}-06$ & $6.1 \mathrm{E}-06$ & $3.6 \mathrm{E}-06$ & $\begin{array}{l}4.4 \mathrm{E}-06 \\
4 \mathrm{~s}-06\end{array}$ & & & $5.5 \mathrm{E}-06$ & $\begin{array}{l}\text {. } 1.2 \mathrm{E}-\mathrm{U} \\
1.1 \mathrm{E}-02\end{array}$ & \\
\hline Pu455 & 0.99 & 86.53 & 271.86 & 0.30 & 4.1 & 2.2 & 4.8 & 1.5 & 1.3 & $N D<1$ & 24.9 & 5.0 & $3.6 \mathrm{E}+01$ & $2.9 \mathrm{E}+00$ & $6611-06$ & $67 \mathrm{E}-06$ & $4.9 \mathrm{E}-06$ & $5.5 \mathrm{E}-06$ & & $10 \mathrm{E}-04$ & $\begin{array}{l}6.08=06 \\
68 \mathrm{E}-0 .\end{array}$ & $1.5 \mathrm{E}-02$ & $8.4 \mathrm{E}-03$ \\
\hline Pu456 & 0.99 & 87.85 & 279.84 & 0.30 & 4.0 & 2.2 & 3.6 & 1.3 & $N D<1$ & $N D<1$ & 111.1 & 4.3 & $2.2 E+01$ & $1.6 \mathrm{E}+00$ & $6.22-06$ & $5.1 \mathrm{E}-06$ & $4.3 \mathrm{E}-06$ & & & $\begin{array}{l}4.6 \mathrm{E}-05 \\
-105\end{array}$ & $5.9 \mathrm{E}-06$ & $\begin{array}{l}9.4 \mathrm{E}-03 \\
\end{array}$ & $\begin{array}{l}0.4 \mathrm{E}-03 \\
4.7 \mathrm{E}-03\end{array}$ \\
\hline Pu457 & 0.99 & 87.78 & 286.90 & 0.30 & 4.0 & 2.2 & 3.7 & 1.3 & $N D<1$ & $N D<1$ & 8.8 & 4.2 & $2.5 \mathrm{E}+01$ & $1.4 E+00$ & $6.2 \mathrm{E}-06$ & $5.3 \mathrm{E}-06$ & $4.3 \mathrm{E}-06$ & & & $3.7 \mathrm{E}-05$ & $5.8 \mathrm{E}-06$ & $1.0 \mathrm{E}-02$ & $4.1 \mathrm{E}-03$ \\
\hline Pu458 & 0.99 & 89.75 & 296.85 & 0.30 & 3.9 & 2.9 & 4.1 & 1.2 & 1.0 & $N D<1$ & 5.7 & 4.3 & $1.8 \mathrm{E}+01$ & $8.0 \mathrm{E}-01$ & $8.2 \mathrm{E}-06$ & $6.0 \mathrm{E}-06$ & $4.0 \mathrm{E}-06$ & $4.4 \mathrm{E}-06$ & & 2.4E-05 & $6.0 \mathrm{E}-06$ & $7.8 \mathrm{E}-03$ & 2.4E-03 \\
\hline Pu459 & 0.99 & 90.40 & 299.85 & 0.30 & 3.9 & 2.9 & 5.4 & 2.2 & 2.0 & 4.4 & 13.6 & 4.8 & $3.2 \mathrm{E}+01$ & $1.4 \mathrm{E}+00$ & $8.3 \mathrm{E}-06$ & $7.9 \mathrm{E}-06$ & $7.4 \mathrm{E}-06$ & $8.9 \mathrm{E}-06$ & $1.3 \mathrm{E}-03$ & $5.8 \mathrm{E}-05$ & $6.8 \mathrm{E}-06$ & $1.4 \mathrm{E}-02$ & $4.3 \mathrm{E}-03$ \\
\hline Pu460 & 0.98 & 92.17 & 315.81 & 0.30 & 3.9 & 2.6 & 3.7 & 1.2 & $N D<1$ & $N D<1$ & 9.3 & 3.9 & $2.6 \mathrm{E}+01$ & $1.1 \mathrm{E}+00$ & $7.6 \mathrm{E}-06$ & $5.5 \mathrm{E}-06$ & $4.1 \mathrm{E}-06$ & & & $4.1 \mathrm{E}-05$ & $5.6 \mathrm{E}-06$ & $1.2 \mathrm{E}-02$ & $3.4 \mathrm{E}-03$ \\
\hline Pu461 & 0.98 & 93.38 & 323.88 & 0.30 & 3.8 & 2.4 & 3.6 & 1.1 & $N D<1$ & $N D<1$ & 8.3 & 4.0 & $2.7 E+01$ & $1.1 \mathrm{E}+00$ & 7.2E- 06 & $5.4 \mathrm{E}-06$ & $3.8 \mathrm{E}-06$ & & & $3.7 \mathrm{E}-05$ & $5.8 \mathrm{E}-06$ & $1.2 \mathrm{E}-02$ & $3.5 \mathrm{E}-03$ \\
\hline Pu462 & 0.98 & 95.74 & 335.89 & 0.30 & 3.9 & 2.2 & 3.4 & 1.1 & $N D<1$ & $N D<1$ & 8.0 & 3.5 & $3.2 \mathrm{E}+01$ & $1.4 \mathrm{E}+00$ & $6.9 \mathrm{E}-06$ & 5.3E-06 & $3.9 \mathrm{E}-06$ & & & 3.6E-05 & $5.2 \mathrm{E}-06$ & $1.5 \mathrm{E}-02$ & $4.5 \mathrm{E}-03$ \\
\hline $\begin{array}{l}\text { Pu463 } \\
\text { Put64 }\end{array}$ & 0.98 & $\begin{array}{l}95.76 \\
8184\end{array}$ & $\begin{array}{r}341.89 \\
358.87\end{array}$ & 0.30 & 3.8 & $\begin{array}{l}2.3 \\
2.4\end{array}$ & 3.3 & $\begin{array}{l}1.0 \\
1.2\end{array}$ & $N D<1$ & $N D<1$ & 9.6 & $\begin{array}{l}3.4 \\
3.8\end{array}$ & 3.5E+01 & $\begin{array}{l}1.5 \mathrm{E}+00 \\
1\end{array}$ & $\begin{array}{l}6.9 E-06 \\
63-06\end{array}$ & $\begin{array}{l}5.1 \mathrm{E}-06 \\
5\end{array}$ & $\begin{array}{l}3.6 \mathrm{E}-06 \\
3.7 \mathrm{~F}-6\end{array}$ & & & -05 & $\begin{array}{l}5.1 \mathrm{E}-06 \\
4 \mathrm{~F}-06\end{array}$ & $\begin{array}{l}1.6 \mathrm{E}-02 \\
87 \mathrm{~F}\end{array}$ & $\begin{array}{l}1.8 \mathrm{E}-03 \\
3 \mathrm{E}-03\end{array}$ \\
\hline $\begin{array}{l}\text { Pu464 } \\
\text { Pu465 }\end{array}$ & $\begin{array}{l}0.98 \\
0.98\end{array}$ & $\begin{array}{l}81.84 \\
84.38\end{array}$ & $\begin{array}{l}355.87 \\
355.90\end{array}$ & $\begin{array}{l}0.30 \\
0.30\end{array}$ & $\begin{array}{l}3.8 \\
3.8\end{array}$ & $\begin{array}{l}2.4 \\
2.2\end{array}$ & $\begin{array}{l}3.8 \\
3.2\end{array}$ & $\begin{array}{l}1.2 \\
1.1\end{array}$ & $\begin{array}{l}N<1 \\
N D<1\end{array}$ & $\begin{array}{l}N D<1 \\
N D<1\end{array}$ & $\begin{array}{l}8.1 \\
6.3\end{array}$ & $\begin{array}{l}3.8 \\
3.1\end{array}$ & $\begin{array}{l}2.2 E+01 \\
2.2 E+01\end{array}$ & $\begin{array}{l}1.3 \mathrm{E}+00 \\
9.0 \mathrm{E}-01\end{array}$ & $\begin{array}{l}6.3-3 \mathrm{E}-06 \\
5.8 \mathrm{E}-06\end{array}$ & $\begin{array}{l}5.0 \mathrm{E}-06 \\
4.4 \mathrm{E}-06\end{array}$ & $\begin{array}{l}3.7 \mathrm{E}-06 \\
3.5 \mathrm{E}-06\end{array}$ & & & $\begin{array}{l}3.2 .2-55 \\
2.5 E-05\end{array}$ & $\begin{array}{l}4.9 \mathrm{E}-06 \\
4.1 \mathrm{E}-06\end{array}$ & $\begin{array}{l}8.77-03 \\
9.1 E-03\end{array}$ & $\begin{array}{l}3.6 \mathrm{E}-03 \\
2.6 \mathrm{E}-03\end{array}$ \\
\hline Pu466 & 0.98 & 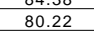 & $\begin{array}{l}3655.90 \\
363.85\end{array}$ & $\begin{array}{l}0.30 \\
0.30\end{array}$ & 3.8 & 3.2 & $\begin{array}{l}3.2 \\
3.5\end{array}$ & 1.1 & $N D<1$ & $\begin{array}{l}\mathrm{N} D<1 \\
\mathrm{ND}<1\end{array}$ & $\begin{array}{l}0.9 \\
10.9\end{array}$ & $\begin{array}{l}3.1 \\
3.7\end{array}$ & $\begin{array}{l}2.2 \mathrm{E}+01 \\
3.6 \mathrm{E}+01\end{array}$ & $\begin{array}{l}9.0 E-10 \\
1.9 E+00\end{array}$ & $\begin{array}{l}5.88-06 \\
8.3 \mathrm{E}-06\end{array}$ & $\begin{array}{l}4.4 \mathrm{E}-06 \\
4.6 \mathrm{E}-06\end{array}$ & $\begin{array}{l}3.5 \mathrm{E}-06 \\
3.3 \mathrm{E}-06\end{array}$ & & & $\begin{array}{l}2.5 \mathrm{E}-55 \\
4.2 \mathrm{E}-05\end{array}$ & 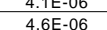 & $\begin{array}{l}9.1 E-1 E-3 \\
1.4 E-02\end{array}$ & $\begin{array}{l}2.6 \mathrm{E}-03 \\
5.1 \mathrm{E}-03\end{array}$ \\
\hline Pu467 & 0.98 & 58.19 & 377.80 & 0.30 & 3.4 & 3.6 & 5.7 & 1.4 & 1.5 & $N D<1$ & 12.9 & 5.0 & $2.8 \mathrm{E}+01$ & $1.7 \mathrm{E}+00$ & $6.8 \mathrm{E}-06$ & $5.4 \mathrm{E}-06$ & 3.1E-06 & 4.3E-06 & & $\begin{array}{l}4.2 E-05 \\
3.6 \mathrm{E}-05\end{array}$ & $\begin{array}{l}\text { 4.6E-06 } \\
4.6 \mathrm{E}-06\end{array}$ & 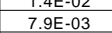 & $\begin{array}{l}\text { 5.1E }-03 \\
3.3 \mathrm{E}-03\end{array}$ \\
\hline Pu468 & 0.98 & 57.08 & 385.88 & 0.30 & 3.1 & 4.7 & 5.1 & 1.3 & 1.3 & $N D<1$ & 12.9 & 4.4 & $3.6 \mathrm{E}+01$ & $2.2 \mathrm{E}+00$ & $8.6 \mathrm{E}-06$ & 4.7E-06 & $2.8 \mathrm{E}-06$ & 3.7E-06 & & $3.5 \mathrm{E}-05$ & $3.9 \mathrm{E}-06$ & $9.9 \mathrm{E}-03$ & $4.2 \mathrm{E}-03$ \\
\hline Pu469 & 0.98 & 55.47 & 390.90 & 0.30 & 3.9 & 15.7 & 9.2 & $N D<1$ & $N D<1$ & $N D<1$ & 14.6 & 2.8 & $2.9 \mathrm{E}+01$ & $1.5 \mathrm{E}+00$ & $2.8 \mathrm{E}-05$ & $8.3 \mathrm{E}-06$ & & & & 3.9E-05 & $2.4 \mathrm{E}-06$ & $7.6 \mathrm{E}-03$ & $2.8 \mathrm{E}-03$ \\
\hline Pu470 & 0.98 & 55.53 & 399.90 & 0.30 & 4.1 & 21.6 & 6.1 & $N D<1$ & $N D<1$ & $N D<1$ & 21.7 & 3.6 & $5.5 \mathrm{E}+01$ & 4.1E+00 & $3.9 \mathrm{E}-05$ & $5.5 \mathrm{E}-06$ & & & & $5.7 E-05$ & $3.1 \mathrm{E}-06$ & $1.5 \mathrm{E}-02$ & $7.7 \mathrm{E}-03$ \\
\hline Pu471 & 0.98 & 63.13 & 405.87 & 0.30 & 3.9 & 1.4 & 4.9 & $N D<1$ & $\mathrm{ND}<1$ & $N D<1$ & 13.4 & 2.0 & 2.4E+01 & $2.0 \mathrm{E}+00$ & $2.8 \mathrm{E}-06$ & $5.0 \mathrm{E}-06$ & & & & $4.0 E-05$ & $2.0 \mathrm{E}-06$ & $7.3 \mathrm{E}-03$ & $4.3 \mathrm{E}-03$ \\
\hline Pu472 & 0.98 & 60.93 & 419.89 & 0.30 & 3.5 & 1.6 & 3.7 & 1.9 & $N D<1$ & $N D<1$ & 38.3 & 3.7 & $3.0 E+01$ & $4.9 \mathrm{E}+00$ & $3.2 \mathrm{E}-06$ & 3.7E-06 & 4.4E-06 & & & 1.1E-04 & $3.5 \mathrm{E}-06$ & $8.9 \mathrm{E}-03$ & $1.0 \mathrm{E}-02$ \\
\hline Pu473 & 0.98 & 59.35 & 433.94 & 0.30 & 3.7 & 1.8 & 4.5 & $N D<1$ & $N D<1$ & $N D<1$ & 21.7 & 3.0 & $3.5 \mathrm{E}+01$ & $4.2 \mathrm{E}+00$ & 3.4E- 06 & $4.3 \mathrm{E}-06$ & & & & $6.2 \mathrm{E}-05$ & $2.8 \mathrm{E}-06$ & $1.0 \mathrm{E}-02$ & $8.4 \mathrm{E}-03$ \\
\hline Pu474 & 0.98 & 59.61 & 447.89 & 0.30 & 3.4 & 1.8 & 3.7 & $N D<1$ & $N D<1$ & $N D<1$ & 18.4 & 2.9 & $4.6 \mathrm{E}+01$ & $2.5 \mathrm{E}+00$ & $3.5 \mathrm{E}-06$ & $3.6 \mathrm{E}-06$ & & & & $5.2 \mathrm{E}-05$ & $2.7 \mathrm{E}-06$ & $1.3 \mathrm{E}-02$ & $5.0 \mathrm{E}-03$ \\
\hline Pu475 & 0.98 & 59.66 & 460.90 & 0.30 & 3.9 & 1.7 & 3.7 & $N D<1$ & $N D<1$ & $N D<1$ & 18.7 & 2.1 & $3.5 E+01$ & $2.4 \mathrm{E}+00$ & 3.2E- 06 & 3.6E-06 & & & & & $2.0 \mathrm{E}-06$ & $1.0 \mathrm{E}-02$ & $4.8 \mathrm{E}-03$ \\
\hline $\begin{array}{l}\text { Pu476 } \\
\text { Put77 }\end{array}$ & 0.98 & $\begin{array}{l}58.00 \\
58.94\end{array}$ & $\begin{array}{l}477.89 \\
4850\end{array}$ & 0.30 & 4.7 & $\begin{array}{l}1.7 \\
1.8\end{array}$ & 3.7 & $N D<1$ & $N D<1$ & $N D<1$ & 22.5 & 1.6 & $4.6 \mathrm{E}+01$ & $3.6 \mathrm{E}+00$ & 3.2E-06 & $3.5 \mathrm{E}-06$ & & & & $6.2 E-05$ & $1.5 \mathrm{E}-06$ & $1.3 \mathrm{E}-02$ & 7.1E-03 \\
\hline $\begin{array}{l}\text { Pu477 } \\
\text { Pu478 }\end{array}$ & $\begin{array}{l}0.98 \\
0.98\end{array}$ & $\begin{array}{l}58.94 \\
34.51\end{array}$ & $\begin{array}{l}485.90 \\
503.38\end{array}$ & $\begin{array}{l}0.30 \\
0.30\end{array}$ & $\begin{array}{l}3.9 \\
4.0\end{array}$ & $\begin{array}{l}1.8 \\
2.9\end{array}$ & & & & & & & & & $\begin{array}{l}3.3 \mathrm{E}-06 \\
32-06\end{array}$ & & & & & & & & \\
\hline $\begin{array}{l}\text { Pu478 } \\
\text { Pu479 }\end{array}$ & $\begin{array}{l}0.98 \\
0.98\end{array}$ & $\begin{array}{l}\begin{array}{l}34.51 \\
38.68\end{array} \\
3\end{array}$ & $\begin{array}{l}503.38 \\
511.38\end{array}$ & $\begin{array}{l}0.30 \\
0.30\end{array}$ & $\begin{array}{l}4.0 \\
4.0\end{array}$ & $\begin{array}{l}2.9 \\
2.9\end{array}$ & & & & & & & & & 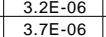 & & & & & & & & \\
\hline Pu480 & 0.98 & 36.94 & 531.48 & 0.30 & 4.0 & 2.5 & & & & & & & & & $\begin{array}{l}3.0 \mathrm{E}-06 \\
3\end{array}$ & & & & & & & & \\
\hline Pu481 & 0.98 & 36.54 & 553.39 & 0.29 & 4.1 & 2.5 & & & & & & & & & $2.9 \mathrm{E}-06$ & & & & & & & & \\
\hline Pu482 & 0.97 & 35.49 & 575.38 & 0.29 & 4.1 & 2.4 & & & & & & & & & $2.7 \mathrm{E}-06$ & & & & & & & & \\
\hline Pu483 & 0.97 & 36.79 & 602.40 & 0.29 & 4.1 & 2.3 & & & & & & & & & $2.8 \mathrm{E}-06$ & & & & & & & & \\
\hline Pu484 & 0.97 & 38.03 & 624.40 & 0.29 & 4.1 & 2.2 & & & & & & & & & $2.7 \mathrm{E}-06$ & & & & & & & & \\
\hline Pu485 & 0.97 & 44.90 & 657.34 & 0.29 & 4.0 & 2.0 & & & & & & & & & $2.9 \mathrm{E}-06$ & & & & & & & & \\
\hline Pu486 & 0.97 & 42.39 & 679.42 & 0.29 & 4.1 & 2.0 & & & & & & & & & $2.7 \mathrm{E}-06$ & & & & & & & & \\
\hline $\begin{array}{l}\text { Average } \\
\text { \% loss }\end{array}$ & $\begin{array}{l}0.97 \\
2.54\end{array}$ & & & & & & & & & & & & & & & & & & & & & & \\
\hline \% loss & 2.54 & & & & & & & & & & & & & & & & & & & & & & \\
\hline $25 \mathrm{C}$ data & Mass & $\begin{array}{l}\text { Flow Rate } \\
(\mathrm{mL} / \text { day) }\end{array}$ & Run time & SurfArea & $\mathrm{pH}$ & $\mathrm{Pu}$ & u & $\mathrm{Hf}$ & Gd & $\mathrm{Ga}$ & $\mathrm{Ca}$ & $\pi$ & $\mathrm{Zn}$ & $\mathrm{Mg}$ & NR-Pu(pH6) & NR-U(pH6) & NR-Hf & NR-Gd(pH6) & NR-Ga & $\mathrm{NR}-\mathrm{Ca}$ & NR-TI & NR-Zn & NR-Mg \\
\hline $\begin{array}{l}\text { pH } 6 \\
\text { start }\end{array}$ & $\begin{array}{l}\text { (g) } \\
1.00\end{array}$ & $\begin{array}{l}(\mathrm{mLL} \text { day) } \\
\mathrm{mL} / \text { day }\end{array}$ & (days) & $\begin{array}{l}\text { (sq. m) } \\
0.30\end{array}$ & 5.9 & $\mathrm{ppb}$ & ppb & $\mathrm{ppb}$ & $\mathrm{ppb}$ & ppb & ppb & $\mathrm{ppb}$ & $\mathrm{ppb}$ & $\mathrm{ppb}$ & $g / m^{\wedge} 2 / d a y$ & $g / m^{\wedge} 2 /$ day & $\mathrm{g} / \mathrm{m}^{\wedge} 2 / \mathrm{day}$ & $g / m^{\wedge} 2 / d a y$ & g/m^2/day & $\mathrm{g} / \mathrm{m}^{\wedge} \mathrm{z} / \mathrm{day}$ & $\mathrm{g} / \mathrm{m}^{\wedge} 2 / \mathrm{day}$ & $g / m^{\wedge} 2 / d a y$ & $g / m^{\wedge} 2 / d a y$ \\
\hline Pu601 & 1.00 & 14.43 & 0.35 & 0.30 & 5.8 & 29.9 & & & & & & & & & 1.4E-05 & & & & & & & & \\
\hline Pu602 & 1.00 & 14.42 & 1.20 & 0.30 & 5.8 & 20.8 & 1263.0 & $\mathrm{ND}<0.5$ & 158.0 & & & 1.4 & & & $9.5 \mathrm{E}-06$ & $2.9 \mathrm{E}-04$ & & $1.1 \mathrm{E}-04$ & & & $3.1 \mathrm{E}-07$ & & \\
\hline Рu603 & 1.00 & 14.32 & 2.40 & 0.30 & 5.9 & 19.3 & 673.0 & $N D<0.5$ & 172.0 & & & 2.0 & & & $8.8 \mathrm{E}-06$ & $1.5 \mathrm{E}-04$ & & $1.2 \mathrm{E}-04$ & & & 4.4E- 07 & & \\
\hline Pu604 & 1.00 & 14.61 & 3.01 & 0.30 & 5.7 & 17.8 & & & & & & & & & $8.2 E-06$ & & & & & & & & \\
\hline Pu605 & 1.00 & 14.36 & 5.84 & 0.30 & 5.7 & 15.0 & & & & & & & & & $6.8 \mathrm{E}-06$ & & & & & & & & \\
\hline Pu606 & 1.00 & 14.30 & 7.87 & 0.30 & 5.6 & 13.1 & & & & & & & & & $5.9 \mathrm{E}-06$ & & & & & & & & \\
\hline Pu607 & 1.00 & 14.29 & 9.88 & 0.30 & 5.6 & 11.6 & & & & & & & & & $5.3 \mathrm{E}-06$ & & & & & & & & \\
\hline Pu608 & 1.00 & 13.77 & 12.90 & 0.30 & 5.7 & 10.8 & & & & & & & & & $4.7 E-06$ & & & & & & & & \\
\hline Pu609 & 1.00 & 14.33 & 15.88 & 0.30 & 5.7 & 9.5 & & & & & & & & & $4.3 \mathrm{E}-06$ & & & & & & & & \\
\hline Poro & 1.00 & 14.10 & 19.88 & 0.30 & 5.6 & 8.8 & & & & & & & & & S.GE-Ub & & & & & & & & \\
\hline Pu611 & 1.00 & $\begin{array}{r}14.12 \\
1.395\end{array}$ & 22.86 & 0.30 & 5.6 & 8.4 & & & & & & & & & $\begin{array}{l}3.8 \mathrm{E}-06 \\
35-06\end{array}$ & & & & & & & & \\
\hline $\begin{array}{l}\text { Pu612 } \\
\text { Pu613 }\end{array}$ & $\begin{array}{l}1.00 \\
1.00\end{array}$ & $\begin{array}{l}13.95 \\
13.95\end{array}$ & $\begin{array}{l}26.86 \\
29.89\end{array}$ & $\begin{array}{l}0.30 \\
0.30\end{array}$ & 5.6 & $\begin{array}{l}7.9 \\
7.8\end{array}$ & 560 & $N D=05$ & 530 & & & 34 & & & $\begin{array}{l}3.5 \mathrm{E}-06 \\
35-06\end{array}$ & $13 \mathrm{E}-05$ & & $36 \mathrm{~F}-05$ & & & 74F-07 & & \\
\hline $\begin{array}{l}\text { Pub13 } \\
\text { Pu614 }\end{array}$ & $\begin{array}{l}1.00 \\
1.00\end{array}$ & $\begin{array}{l}\begin{array}{l}3.95 \\
13.31\end{array} \\
\end{array}$ & $\begin{array}{l}29.89 \\
37.91\end{array}$ & $\begin{array}{l}0.30 \\
0.30\end{array}$ & $\begin{array}{l}5.7 \\
5.6\end{array}$ & $\begin{array}{l}7.8 \\
7.2\end{array}$ & 56.0 & $N D<0.5$ & 53.0 & & & 3.4 & & & $\begin{array}{l}\begin{array}{l}3.5-5-06 \\
3.0 E-06\end{array} \\
\end{array}$ & $1.3 \mathrm{E}-05$ & & $3.6 \mathrm{E}-05$ & & & $7.4 \mathrm{E}-07$ & & \\
\hline Pu615 & 1.00 & 23 & 48.88 & 0.3 & 5.7 & 4.6 & 21.0 & $N D<0.5$ & 24.0 & & & 2.2 & & & 3.4E-06 & $7.8 \mathrm{E}-06$ & & $2.7 \mathrm{E}-05$ & & & $7.9 \mathrm{E}-07$ & & \\
\hline Pu616 & 1.00 & 24 & 51.83 & 0. & 5.6 & 3.7 & & & & & & & & & 2.9 & & & & & & & & \\
\hline Pu617 & 1.00 & 22.27 & 55.90 & 0.30 & 5.7 & 3.7 & 16.0 & $N D<0.5$ & 28.0 & & & 1.3 & & & $2.6 \mathrm{E}-06$ & $5.7 \mathrm{E}-06$ & & $3.0 \mathrm{E}-05$ & & & $4.5 \mathrm{E}-07$ & & \\
\hline $\begin{array}{l}\text { Pu618 } \\
\text { Pffto }\end{array}$ & 1.00 & $\begin{array}{r}23.50 \\
23.71\end{array}$ & 58.83 & 0.30 & 5.7 & 3.5 & & & & & & & & & $2.6 E-06$ & & & & & & $375-07$ & & \\
\hline $\begin{array}{l}\text { Pu619 } \\
\text { P6620 }\end{array}$ & $\begin{array}{l}1.00 \\
1.00\end{array}$ & $\begin{array}{l}23.71 \\
23.14\end{array}$ & $\begin{array}{l}62.39 \\
65.82\end{array}$ & $\begin{array}{l}0.30 \\
0.30\end{array}$ & $\begin{array}{l}5.8 \\
5.7\end{array}$ & $\begin{array}{l}3.5 \\
3.5\end{array}$ & 11.0 & $\mathrm{ND}<0.5$ & 21.0 & & & 1.0 & & & $\begin{array}{l}2.75-06 \\
2.5 E-06\end{array}$ & 4.2E- -06 & & 2.4E-05 & & & $3.7 \mathrm{E}-07$ & & \\
\hline Pu621 & 1.00 & 21 & 69 & 0 & 5.7 & 3.4 & 14.0 & $\mathrm{ND}<0.5$ & 21.0 & & & 1.1 & & & 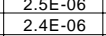 & $4.8 \mathrm{E}-06$ & & $2.2 \mathrm{E}-05$ & & & $3.7 \mathrm{E}-07$ & & \\
\hline Pu622 & 1.00 & 18 & 72 & 0. & 5.8 & 3.7 & & & & & & & & & 2. & & & & & & & & \\
\hline Pu623 & 1.00 & 22 & 76.89 & 0. & 5.8 & 2.8 & 10.0 & $N D<0.5$ & 21.0 & & & 0.9 & & & 2. & 3.7E-06 & & $2.3 \mathrm{E}-05$ & & & $3.2 \mathrm{E}-07$ & & \\
\hline Pu624 & 1.00 & 20.91 & 83.86 & 0. & 5.7 & 3.2 & & & & & & & & & $2.1 \mathrm{E}-06$ & & & & & & & & \\
\hline $\begin{array}{l}\text { Pu625 } \\
\text { Puf26 }\end{array}$ & $\begin{array}{l}1.00 \\
1.00\end{array}$ & $\begin{array}{l}24.68 \\
31.99\end{array}$ & $\begin{array}{l}86.87 \\
90.94\end{array}$ & 0.3 & 5.7 & $\begin{array}{l}2.4 \\
25\end{array}$ & 8.0 & $\mathrm{ND}<0.5$ & 20.0 & & & 0.7 & & & $\begin{array}{l}1.9 E-06 \\
26-5\end{array}$ & $3.2 \mathrm{E}-06$ & & 2.4E-05 & & & 2.7E-07 & & \\
\hline $\begin{array}{l}\text { Pub26 } \\
\text { Pu627 }\end{array}$ & $\begin{array}{l}1.00 \\
1.00\end{array}$ & $\begin{array}{l}31 \\
31\end{array}$ & $\begin{array}{l}90.94 \\
93.90\end{array}$ & 0. & $\begin{array}{l}5.7 \\
5.7\end{array}$ & $\begin{array}{l}2.5 \\
1.7\end{array}$ & 5.8 & $\mathrm{ND}<0.5$ & 17.0 & & & $N D<0.5$ & & & -06 & $3.0 \mathrm{E}-06$ & & $2.6 \mathrm{E}-05$ & & & & & \\
\hline Puf & 1.0 & 9. & & 0 & 5.7 & 5.3 & & & & & & & & & & & & & & & & & \\
\hline $\mathrm{Pu}$ & 1.00 & & & & 5.6 & 5.6 & 13.0 & $\mathrm{ND}<0.5$ & 17 & & & 1. & & & & 6 & & 6 & & & 07 & & \\
\hline Рu630 & 1.00 & 8.93 & 113 & 0.3 & 5.6 & 4.5 & 12.0 & $\mathrm{NL}$ & 16.0 & 3.8 & 149.9 & 4. & $3.7 E+01$ & $6.6 \mathrm{E}-\mathrm{s}$ & 1.3 & $1.7 \mathrm{E}-06$ & & $7.0 \mathrm{E}-06$ & 1.1E-04 & & 07 & $1.6 \mathrm{E}-03$ & $2.0 \mathrm{E}-03$ \\
\hline Pu631 & 1.00 & $\begin{array}{r}47.19 \\
45.13\end{array}$ & 119.91 & 0.3 & 5.8 & 0.9 & 7.9 & $N D<1$ & 19.0 & 4.8 & 141.3 & 11.0 & $5.9 \mathrm{E}+01$ & $1.2 \mathrm{E}+01$ & 1.4E- -06 & $6.0 \mathrm{E}-06$ & & 4.4E-05 & 7.6E-04 & $3.1 \mathrm{E}-04$ & $8.1 \mathrm{E}-06$ & $1.3 \mathrm{E}-02$ & $1.8 \mathrm{E}-02$ \\
\hline Pu632 & 1.00 & $\begin{array}{l}45.13 \\
1.175\end{array}$ & $\begin{array}{l}125.39 \\
1200\end{array}$ & 0.30 & 5.9 & 1.2 & 3.3 & $N D<1$ & 16.0 & $\mathrm{ND}<3$ & $\begin{array}{l}106.4 \\
207\end{array}$ & 1.8 & $2.2 \mathrm{E}+00$ & $3.2 \mathrm{E}+00$ & $\begin{array}{l}1.7 E-06 \\
1\end{array}$ & 2.4E-06 & & 3.5E-05 & & $2.3 \mathrm{E}-04$ & $1.3 \mathrm{E}-06$ & 4.7E-04 & $4.8 \mathrm{E}-03$ \\
\hline Рu633 & 1.00 & $\begin{array}{l}41.75 \\
40.25\end{array}$ & $\begin{array}{l}132.92 \\
\end{array}$ & 0.30 & 5.9 & $\begin{array}{l}1.3 \\
1.3\end{array}$ & $\begin{array}{l}7.4 \\
5.5\end{array}$ & $\begin{array}{l}N D<1 \\
N D<1\end{array}$ & 31.0 & $\begin{array}{l}4.3 \\
3.7\end{array}$ & $\begin{array}{l}227.7 \\
191.8\end{array}$ & 5.2 & $5.3 \mathrm{E}+01$ & $1.0 E+01$ & $\begin{array}{l}1.7 E-06 \\
16 E-02\end{array}$ & $\begin{array}{l}5.0 \mathrm{E}-06 \\
3\end{array}$ & & $6.3 \mathrm{E}-05$ & $6.0 \mathrm{E}-04$ & $\begin{array}{l}4.5 E-04 \\
3\end{array}$ & 3.4E-06 & $1.0 E-02$ & 1.4E-02 \\
\hline $\begin{array}{l}\text { Pub34 } \\
\text { Pu6355 }\end{array}$ & $\begin{array}{l}1.00 \\
1.00\end{array}$ & $\begin{array}{l}40.25 \\
41.21\end{array}$ & $\begin{array}{l}139.88 \\
146.85\end{array}$ & $\begin{array}{l}0.30 \\
0.30\end{array}$ & $\begin{array}{l}5.7 \\
5.7\end{array}$ & $\begin{array}{l}1.3 \\
1.2\end{array}$ & $\begin{array}{l}5.5 \\
4.2\end{array}$ & $\begin{array}{l}N D<1 \\
N D<1\end{array}$ & $\begin{array}{l}30.0 \\
23.0\end{array}$ & $\begin{array}{c}3.7 \\
\mathrm{ND}<3\end{array}$ & $\begin{array}{l}191.8 \\
169.3\end{array}$ & $\begin{array}{l}4.7 \\
7.5\end{array}$ & $\begin{array}{l}5.4 \mathrm{E}+01 \\
9.0 \mathrm{E}+01\end{array}$ & $\begin{array}{l}8.8 \mathrm{E}+000 \\
6.8 \mathrm{E}+00\end{array}$ & $\begin{array}{l}1.6 \mathrm{E}-06 \\
1.6 \mathrm{E}-06\end{array}$ & $\begin{array}{l}3.6 \mathrm{E}-06 \\
2.8 \mathrm{E}-06\end{array}$ & & $\begin{array}{l}5.9 \mathrm{E}-05 \\
4.6 \mathrm{E}-05\end{array}$ & 5.0E-04 & $\begin{array}{l}3.6 \mathrm{E}-04 \\
3.3 \mathrm{E}-04\end{array}$ & $\begin{array}{l}2.9 \mathrm{E}-06 \\
4.8 \mathrm{E}-06\end{array}$ & $\begin{array}{l}1.0 \mathrm{E}-02 \\
1.8 \mathrm{E}-02\end{array}$ & $\begin{array}{l}1.2 \mathrm{E}-02 \\
94 \mathrm{~F}-2\end{array}$ \\
\hline
\end{tabular}

Page 40 
SPFT Data Table

\begin{tabular}{|c|c|c|c|c|c|c|c|c|c|c|c|c|c|c|c|c|c|c|c|c|c|c|}
\hline Pu636 & 1.00 & 39.30 & 15288 & 0,30 & 58 & 1.2 & 3.7 & $\mathrm{ND<1}$ & 210 & $\mathrm{ND}<3$ & 157.2 & 33 & $6.0 \mathrm{E}+01$ & $5.2 E+00$ & $1.5 \mathrm{E}-06$ & $2.3 \mathrm{E}-06$ & $4.0 \mathrm{E}-05$ & & $2.9 \mathrm{E}-04$ & $2.0 \mathrm{E}-06$ & $1.1 \mathrm{E}-02$ & $6.8 \mathrm{E}-03$ \\
\hline Pu637 & 1.00 & 58.51 & 168.01 & 0.30 & $\begin{array}{l}5.8 \\
5.8\end{array}$ & 0.8 & 4.9 & $\mathrm{ND}<1$ & 9.0 & 3.8 & 80.3 & 8.4 & $5.2 \mathrm{E}+01$ & $6.4 \mathrm{E}+00$ & $1.4 \mathrm{E}-06$ & $\begin{array}{l}2.3 \mathrm{E}-0 \mathrm{0} \\
4.6 \mathrm{E}-06\end{array}$ & $2.6 \mathrm{E}-05$ & 7.4E- -04 & $2.2 \mathrm{E}-04$ & $7.6 \mathrm{E}-06$ & $1.5 \mathrm{E}-02$ & $1.3 \mathrm{E}-02$ \\
\hline Pu638 & 1.00 & 53.58 & 174.85 & 0.30 & 5.8 & 0.8 & 2.7 & $N D<1$ & 12.0 & $N D<3$ & 90.3 & 7.3 & $3.4 \mathrm{E}+01$ & $4.3 \mathrm{E}+00$ & $1.4 \mathrm{E}-06$ & $2.3 \mathrm{E}-06$ & $3.1 \mathrm{E}-05$ & & $2.3 \mathrm{E}-04$ & $6.1 \mathrm{E}-06$ & $8.8 \mathrm{E}-03$ & $7.7 \mathrm{E}-03$ \\
\hline Pu639 & 1.00 & 52.88 & 181.88 & 0.30 & 5.9 & 0.9 & 2.8 & $N D<1$ & 13.0 & $N D<3$ & 87.7 & 2.1 & $3.8 \mathrm{E}+01$ & $3.9 \mathrm{E}+00$ & $1.5 \mathrm{E}-06$ & $2.4 \mathrm{E}-06$ & 3.4E-05 & & $2.2 \mathrm{E}-04$ & 1.7E-06 & $9.6 \mathrm{E}-03$ & $6.9 \mathrm{E}-03$ \\
\hline Pu640 & 1.00 & 50.92 & 188.92 & 0.30 & 5.8 & 0.9 & 3.1 & $N D<1$ & 13.0 & $N D<3$ & 93.8 & 1.9 & $2.7 E+01$ & $4.1 \mathrm{E}+00$ & $1.4 \mathrm{E}-06$ & $2.5 \mathrm{E}-06$ & 3.2E-05 & & $2.3 \mathrm{E}-04$ & $1.5 \mathrm{E}-06$ & $6.6 \mathrm{E}-03$ & $7.0 \mathrm{E}-03$ \\
\hline $\begin{array}{l}\text { Pu641 } \\
\text { Puf6? }\end{array}$ & 1.00 & 50.87 & 195.91 & 0.30 & 5.8 & 0.9 & 3.1 & $N D<1$ & $\begin{array}{l}13.0 \\
15.0\end{array}$ & $\begin{array}{l}N D<3 \\
\end{array}$ & 83.6 & 1.8 & 3.0E+01 & $4.7 \mathrm{E}+00$ & $1.4 \mathrm{E}-06$ & 2.5E-06 & 3.2E-05 & & $2.0 \mathrm{E}-04$ & 1.4E-06 & 7.3E-03 & $8.0 E-03$ \\
\hline $\begin{array}{l}\text { Pu662 } \\
\text { Pu643 }\end{array}$ & $\begin{array}{l}1.00 \\
1.00\end{array}$ & $\begin{array}{l}53.08 \\
48.75\end{array}$ & $\begin{array}{l}202.88 \\
209.88\end{array}$ & $\begin{array}{l}0.30 \\
0.30\end{array}$ & $\begin{array}{l}6.0 \\
5.8\end{array}$ & $\begin{array}{l}0.7 \\
1.1\end{array}$ & $\begin{array}{l}2.7 \\
2.8\end{array}$ & $\begin{array}{l}N D<1 \\
N D<1\end{array}$ & $\begin{array}{l}15.0 \\
20.0\end{array}$ & $\begin{array}{l}N D<3 \\
N D<3\end{array}$ & $\begin{array}{l}109.7 \\
129.8\end{array}$ & $\begin{array}{l}2.4 \\
2.5\end{array}$ & $\begin{array}{l}2.8 \mathrm{E}+01 \\
3\end{array}$ & $\begin{array}{l}4.5 \mathrm{E}+00 \\
6.4 \mathrm{E}+00\end{array}$ & $\begin{array}{l}1.2 \mathrm{E}-06 \\
1.7 \mathrm{E}-6\end{array}$ & $\begin{array}{l}2.3 \mathrm{E}-06 \\
2.2 \mathrm{E}-06\end{array}$ & $\begin{array}{l}3.9 \mathrm{E}-05 \\
4.8 \mathrm{E}-05\end{array}$ & & $\begin{array}{l}2.7 \mathrm{E}-04 \\
3.0 \mathrm{E}-04\end{array}$ & $\begin{array}{l}2.0 \mathrm{E}-06 \\
1.5 \mathrm{~F}\end{array}$ & $\begin{array}{l}7.0 \mathrm{E}-03 \\
7\end{array}$ & $8.0 \mathrm{E}-03$ \\
\hline $\begin{array}{l}\text { Pub43 } \\
\text { Pu644 }\end{array}$ & $\begin{array}{l}1.00 \\
1.00\end{array}$ & $\begin{array}{l}48.75 \\
51.97\end{array}$ & $\begin{array}{l}209.88 \\
216.88\end{array}$ & $\begin{array}{l}0.30 \\
0.30\end{array}$ & $\begin{array}{l}5.8 \\
5.8\end{array}$ & $\begin{array}{l}1.1 \\
0.9\end{array}$ & $\begin{array}{l}2.8 \\
2.5\end{array}$ & $\begin{array}{l}N D<1 \\
N D<1\end{array}$ & $\begin{array}{l}20.0 \\
19.0\end{array}$ & $\begin{array}{l}\mathrm{ND}<3 \\
\mathrm{ND}<3\end{array}$ & $\begin{array}{l}129.8 \\
122.5\end{array}$ & $\begin{array}{l}2.5 \\
2.1\end{array}$ & $\begin{array}{l}3.3 \mathrm{E}+01 \\
2.9 \mathrm{E}+01\end{array}$ & $\begin{array}{l}6.4 \mathrm{E}+00 \\
4.8 \mathrm{E}+00\end{array}$ & $\begin{array}{l}1.7 \mathrm{E}-06 \\
1.5 \mathrm{E}-06\end{array}$ & $\begin{array}{l}2.2 E-66 \\
2.1 E-06\end{array}$ & $\begin{array}{l}4.8 \mathrm{E}-05 \\
4.8 \mathrm{E}-05\end{array}$ & & $\begin{array}{l}3.0 \mathrm{E}-04 \\
3.0 \mathrm{E}-04\end{array}$ & $\begin{array}{l}1.9 \mathrm{E}-06 \\
1.7 \mathrm{E}-06\end{array}$ & $\begin{array}{l}7.7 \mathrm{E}-03 \\
7.2 \mathrm{E}-03\end{array}$ & $\begin{array}{l}1.0 \mathrm{O}-02 \\
8.3 \mathrm{E}-03\end{array}$ \\
\hline Pu645 & 1.00 & 52.41 & 223.89 & 0.30 & 5.9 & 0.9 & 2.6 & $N D<1$ & 18.0 & $\mathrm{ND}<3$ & 137.7 & 2.5 & $\begin{array}{l}2.9 \mathrm{E}+01 \\
4.6 \mathrm{E}+01\end{array}$ & $\begin{array}{l}4.88+00 \\
7.7 \mathrm{E}+00\end{array}$ & $\begin{array}{l}1.5 \mathrm{E}-06 \\
1.4 \mathrm{E}-06\end{array}$ & $\begin{array}{l}2.1 E-06 \\
2.2 E-06\end{array}$ & $\begin{array}{l}4.8 \mathrm{E}-05 \\
4.6 \mathrm{E}-05\end{array}$ & & $\begin{array}{l}3.0 E-04 \\
3.4 E-04\end{array}$ & $\begin{array}{l}1.7 \mathrm{E}-06 \\
2.0 \mathrm{E}-06\end{array}$ & $\begin{array}{l}1.2 \mathrm{E}-03 \\
1.1 \mathrm{E}-02\end{array}$ & $\begin{array}{l}.8 .3-03 \\
1.3 \mathrm{E}-02\end{array}$ \\
\hline Pu646 & 1.00 & 50.68 & 237.83 & 0.30 & 6.0 & 0.8 & 2.0 & $N D<1$ & 11.0 & $N D<3$ & & 4.5 & $7.9 \mathrm{E}+01$ & & $\begin{array}{l}1.4 \mathrm{E}-06 \\
1.3 \mathrm{E}-06\end{array}$ & $1.6 \mathrm{E}-06$ & 2.7E-05 & & & $\begin{array}{l}2.0 \mathrm{E}-06 \\
3.5 \mathrm{E}-06\end{array}$ & $\begin{array}{l}1.1 \mathrm{E}-02 \\
1.9 \mathrm{E}-02\end{array}$ & \\
\hline Pu647 & 1.00 & 59.27 & 244.84 & 0.30 & 6.1 & 0.7 & 2.2 & $N D<1$ & 13.0 & $N D<3$ & & 8.5 & $1.3 \mathrm{E}+02$ & & $1.2 \mathrm{E}-06$ & $2.1 \mathrm{E}-06$ & $3.8 \mathrm{E}-05$ & & & $7.8 \mathrm{E}-06$ & $3.7 \mathrm{E}-02$ & \\
\hline Pu648 & 1.00 & 59.86 & 245.82 & 0.30 & 6.1 & 0.7 & 2.5 & $N D<1$ & 15.0 & $N D<3$ & & 3.4 & $8.7 \mathrm{E}+01$ & & $1.3 \mathrm{E}-06$ & $2.4 \mathrm{E}-06$ & $4.4 \mathrm{E}-05$ & & & $3.25-06$ & $2.5 \mathrm{E}-02$ & \\
\hline Pu649 & 1.00 & 61.44 & 246.88 & 0.30 & 6.0 & 0.6 & 1.8 & $N D<1$ & 11.0 & $N D<3$ & & 1.5 & $3.4 E+01$ & & $1.2 \mathrm{E}-06$ & $1.8 \mathrm{E}-06$ & $3.3 \mathrm{E}-05$ & & & $1.4 \mathrm{E}-06$ & $9.9 \mathrm{E}-03$ & \\
\hline Pu650 & 1.00 & 64.06 & 247.86 & 0.30 & 6.0 & 0.6 & 1.7 & $N D<1$ & 10.0 & $N D<3$ & & 6.1 & $4.2 \mathrm{E}+01$ & & $1.3 \mathrm{E}-06$ & $1.7 \mathrm{E}-06$ & $3.1 \mathrm{E}-05$ & & & $6.1 \mathrm{E}-06$ & $1.3 \mathrm{E}-02$ & \\
\hline Pu651 & 1.00 & 61.52 & 250.84 & 0.30 & 6.0 & 0.6 & 2.2 & $\mathrm{ND}<1$ & 13.0 & $\mathrm{ND}<3$ & & 2.3 & $3.1 E+01$ & & $1.3 \mathrm{E}-06$ & $2.2 \mathrm{E}-06$ & $3.9 \mathrm{E}-05$ & & & $2.2 \mathrm{E}-06$ & $9.0 \mathrm{E}-03$ & \\
\hline Pu652 & 1.00 & 62.12 & 254.80 & 0.30 & 6.0 & 0.6 & 2.1 & $N D<1$ & 11.0 & $N D<3$ & & 6.5 & $4.8 \mathrm{E}+01$ & & $1.2 \mathrm{E}-06$ & $2.1 \mathrm{E}-06$ & $3.3 \mathrm{E}-05$ & & & $6.3 \mathrm{E}-06$ & $1.4 \mathrm{E}-02$ & \\
\hline Pu653 & 1.00 & 64.66 & 258.81 & 0.30 & 6.1 & 0.6 & 2.5 & $N D<1$ & 13.0 & $N D<3$ & & 4.8 & $3.7 E+01$ & & $1.3 \mathrm{E}-06$ & $2.6 \mathrm{E}-06$ & 4.1E-05 & & & $4.8 \mathrm{E}-06$ & $1.1 \mathrm{E}-02$ & \\
\hline $\begin{array}{l}\text { Pu654 } \\
\text { Pu655 }\end{array}$ & 1.00 & 64.72 & 266.85 & 0.30 & 6.1 & 0.6 & 2.2 & $N D<1$ & 11.0 & $N D<3$ & & 5.7 & $2.9 \mathrm{E}+01$ & & $1.3 \mathrm{E}-06$ & 2.3E-06 & 3.5E-05 & & & $5.7 \mathrm{E}-06$ & $8.8 \mathrm{E}-03$ & \\
\hline $\begin{array}{l}\text { Pu655 } \\
\text { Pu656 }\end{array}$ & 1.00 & $\begin{array}{l}64.40 \\
63.81\end{array}$ & $\begin{array}{l}271.86 \\
27984\end{array}$ & 0.30 & 6.0 & 0.6 & 2.8 & $\begin{array}{l}N D<1 \\
N D<1\end{array}$ & $\begin{array}{l}15.0 \\
110\end{array}$ & $\begin{array}{l}N D<3 \\
\end{array}$ & $\begin{array}{l}134.1 \\
75.1\end{array}$ & 4.2 & $\begin{array}{l}7.5 \mathrm{E}+01 \\
3\end{array}$ & $7.8 \mathrm{E}+00$ & $1.3 \mathrm{E}-06$ & 2.9E-06 & 4.7E-05 & & 4.1E-04 & 4.2E-06 & $2.3 \mathrm{E}-02$ & 1.7E-02 \\
\hline $\begin{array}{l}\text { Pu656 } \\
\text { Pu657 }\end{array}$ & 1.00 & $\begin{array}{l}63.81 \\
63.46\end{array}$ & $\begin{array}{l}279.84 \\
286.90\end{array}$ & 0.30 & 6.0 & 0.6 & $\begin{array}{l}1.9 \\
2.1\end{array}$ & $\begin{array}{l}N D<1 \\
N D<1\end{array}$ & $\begin{array}{c}10.0 \\
90\end{array}$ & $\begin{array}{l}N D<3 \\
N D<3\end{array}$ & $\begin{array}{l}75.0 \\
7760\end{array}$ & $\begin{array}{l}2.0 \\
2 .\end{array}$ & $\begin{array}{l}3.0 \mathrm{E}+01 \\
3\end{array}$ & $\begin{array}{l}4.1 \mathrm{E}+00 \\
50 \mathrm{~F}+00\end{array}$ & $\begin{array}{l}1.3 \mathrm{E}-06 \\
1.3 \mathrm{E}-06\end{array}$ & $\begin{array}{l}1.9 \mathrm{E}-06 \\
2.1 \mathrm{E}-06\end{array}$ & $\begin{array}{l}3.1 \mathrm{E}-05 \\
28 \mathrm{E}-05\end{array}$ & & $\begin{array}{l}2.3 \mathrm{E}-04 \\
2.3 \mathrm{E}-04\end{array}$ & $\begin{array}{l}2.0 \mathrm{E}-06 \\
2.2 \mathrm{E}-60\end{array}$ & $\begin{array}{l}9.0 \mathrm{E}-03 \\
1.0 \mathrm{E}-02\end{array}$ & $\begin{array}{l}8.7 E-03 \\
111-02\end{array}$ \\
\hline $\begin{array}{l}\text { Pu657 } \\
\text { Pu658 }\end{array}$ & $\begin{array}{l}1.00 \\
1.00\end{array}$ & $\begin{array}{l}63.46 \\
64.69\end{array}$ & $\begin{array}{l}286.90 \\
296.85\end{array}$ & $\begin{array}{l}0.30 \\
0.30\end{array}$ & $\begin{array}{l}6.0 \\
6.0\end{array}$ & $\begin{array}{l}0.7 \\
0.6\end{array}$ & $\begin{array}{l}2.1 \\
1.9\end{array}$ & $\begin{array}{l}\mathrm{ND}<1 \\
\mathrm{ND}<1\end{array}$ & $\begin{array}{l}9.0 \\
7.0\end{array}$ & $\begin{array}{l}\mathrm{ND}<3 \\
\mathrm{ND}<3\end{array}$ & $\begin{array}{l}76.0 \\
58.3\end{array}$ & $\begin{array}{l}2.2 \\
1.3\end{array}$ & $\begin{array}{l}3.3 \mathrm{E}+01 \\
2.8 \mathrm{E}+01\end{array}$ & $\begin{array}{l}5.0 \mathrm{E}+00 \\
3.2 \mathrm{E}+00\end{array}$ & $\begin{array}{l}1.3 \mathrm{E}-06 \\
1.3 \mathrm{E}-06\end{array}$ & $\begin{array}{l}2.1 \mathrm{E}-06 \\
2.0 \mathrm{E}-06\end{array}$ & $\begin{array}{l}2.8 \mathrm{E}-05 \\
2.2 \mathrm{E}-05\end{array}$ & & $\begin{array}{l}2.3 \mathrm{E}-04 \\
1.8 \mathrm{E}-04\end{array}$ & $\begin{array}{l}2.2 \mathrm{E}-06 \\
1.3 \mathrm{E}-06\end{array}$ & $\begin{array}{l}1.0 \mathrm{E}-02 \\
8.7 \mathrm{E}-03\end{array}$ & $\begin{array}{l}1.11 \mathrm{E}-02 \\
6.9 \mathrm{E}-03\end{array}$ \\
\hline Pu659 & 1.00 & 64.80 & 299.89 & 0.30 & 6.0 & 0.7 & 2.1 & $N D<1$ & 8.0 & $\mathrm{ND}<3$ & 67.4 & 2.1 & $4.6 \mathrm{E}+01$ & $4.1 \mathrm{E}+00$ & $\begin{array}{l}1.3 \mathrm{E}-06 \\
1.4 \mathrm{E}-06\end{array}$ & $2.2 \mathrm{E}-06$ & $\begin{array}{l}2.2 \mathrm{E}-05 \\
2.5 \mathrm{E}-05\end{array}$ & & $2.1 \mathrm{E}-04$ & 2.3E-06 & $\begin{array}{l}8.1 \mathrm{E}-03 \\
1.4 \mathrm{E}-02\end{array}$ & $\begin{array}{l}.0 .9-03 \\
8.9 \mathrm{E}-03\end{array}$ \\
\hline Pu660 & 1.00 & 67.24 & 315.82 & 0.30 & 6.0 & 0.5 & 1.7 & $N D<1$ & 6.0 & $N D<3$ & 70.9 & 3.8 & $4.2 \mathrm{E}+01$ & $3.5 \mathrm{E}+00$ & $1.1 \mathrm{E}-06$ & $1.8 \mathrm{E}-06$ & $2.0 \mathrm{E}-05$ & & $2.3 \mathrm{E}-04$ & $4.0 E-06$ & $1.3 \mathrm{E}-02$ & $7.9 E-03$ \\
\hline Pu661 & & & & & 5.8 & & 1.6 & $N D<1$ & & $N D<3$ & 50.5 & & $3.5 \mathrm{E}+01$ & $2.2 \mathrm{E}+00$ & $9.9 \mathrm{E}-07$ & & $2.0 \mathrm{E}-05$ & & $1.6 \mathrm{E}-04$ & $2.8 \mathrm{E}-06$ & $1.1 \mathrm{E}-02$ & $5.0 \mathrm{E}-03$ \\
\hline Pu662 & 1.00 & 64.65 & 335.89 & 0.30 & 5.9 & 0.5 & 1.6 & $N D<1$ & 5.0 & $N D<3$ & 54.0 & 3.3 & $4.5 \mathrm{E}+01$ & $3.5 \mathrm{E}+00$ & $9.4 \mathrm{E}-07$ & $1.7 \mathrm{E}-06$ & $1.6 \mathrm{E}-05$ & & $1.6 \mathrm{E}-04$ & $3.3 \mathrm{E}-06$ & $1.4 \mathrm{E}-02$ & $7.6 \mathrm{E}-03$ \\
\hline Pu663 & 1.00 & 65.07 & 341.89 & 0.30 & 5.6 & 0.5 & 1.7 & $N D<1$ & 6.0 & $N D<3$ & 74.3 & 2.8 & $4.2 \mathrm{E}+01$ & $3.6 \mathrm{E}+00$ & $1.0 \mathrm{E}-06$ & $1.8 \mathrm{E}-06$ & $1.9 \mathrm{E}-05$ & & $2.3 \mathrm{E}-04$ & $2.8 \mathrm{E}-06$ & $1.3 \mathrm{E}-02$ & $7.8 \mathrm{E}-03$ \\
\hline Pu664 & 1.00 & 66.76 & 350.89 & 0.30 & 5.6 & 0.8 & 1.8 & $N D<1$ & 11.0 & $N D<3$ & 94.0 & 1.6 & $2.9 \mathrm{E}+01$ & $3.3 \mathrm{E}+00$ & $1.7 \mathrm{E}-06$ & $1.9 \mathrm{E}-06$ & $3.6 \mathrm{E}-05$ & & $3.0 \mathrm{E}-04$ & $1.7 \mathrm{E}-06$ & $9.3 \mathrm{E}-03$ & 7.4E- 03 \\
\hline Pu665 & 1.00 & 65.77 & 355.90 & 0.30 & 5.7 & 0.6 & 1.5 & $N D<1$ & 9.0 & $\mathrm{ND}<3$ & 75.2 & 1.9 & $4.5 \mathrm{E}+01$ & $2.8 \mathrm{E}+00$ & $1.2 \mathrm{E}-06$ & $1.6 \mathrm{E}-06$ & $2.9 \mathrm{E}-05$ & & $2.3 \mathrm{E}-04$ & $1.9 \mathrm{E}-06$ & $1.4 \mathrm{E}-02$ & $6.2 \mathrm{E}-03$ \\
\hline Pu666 & 1.00 & 48.24 & 363.85 & 0.30 & 5.8 & 0.7 & 1.9 & $N D<1$ & 10.0 & $N D<3$ & 75.9 & 3.0 & $5.6 \mathrm{E}+01$ & $4.1 \mathrm{E}+00$ & $1.1 \mathrm{E}-06$ & $1.5 \mathrm{E}-06$ & $2.4 \mathrm{E}-05$ & & $1.7 \mathrm{E}-04$ & $2.2 \mathrm{E}-06$ & $1.3 \mathrm{E}-02$ & $6.6 \mathrm{E}-03$ \\
\hline Pu667 & 1.00 & 49.87 & 377.84 & 0.30 & 5.4 & 0.8 & 1.9 & $N D<1$ & 6.0 & $N D<3$ & 53.8 & 3.6 & $4.8 \mathrm{E}+01$ & $5.7 \mathrm{E}+00$ & $1.2 \mathrm{E}-06$ & $1.5 \mathrm{E}-06$ & $1.5 \mathrm{E}-05$ & & $1.3 \mathrm{E}-04$ & $2.8 \mathrm{E}-06$ & $1.1 \mathrm{E}-02$ & $9.5 \mathrm{E}-03$ \\
\hline Pu668 & 1.00 & 47.59 & 385.88 & 0.30 & 5.1 & 0.8 & 2.1 & $N D<1$ & 6.0 & $N D<3$ & 59.5 & 3.0 & $5.2 E+01$ & $4.0 \mathrm{E}+00$ & $1.2 \mathrm{E}-06$ & $1.6 \mathrm{E}-06$ & $1.4 \mathrm{E}-05$ & & $1.3 \mathrm{E}-04$ & $2.2 \mathrm{E}-06$ & $1.2 \mathrm{E}-02$ & $6.4 \mathrm{E}-03$ \\
\hline $\begin{array}{l}\text { Pu669 } \\
\text { Pu670 }\end{array}$ & $\begin{array}{l}1.00 \\
1.00\end{array}$ & $\begin{array}{l}46.78 \\
45.88\end{array}$ & $\begin{array}{l}390.90 \\
399.90\end{array}$ & $\begin{array}{l}0.30 \\
0.30\end{array}$ & $\begin{array}{l}5.8 \\
5.8\end{array}$ & $\begin{array}{l}0.7 \\
0.8\end{array}$ & $\begin{array}{c}\mathrm{ND}<1 \\
1.4\end{array}$ & $\begin{array}{l}N D<1 \\
N D<1\end{array}$ & $\begin{array}{l}\mathrm{ND} D<1 \\
1.1\end{array}$ & $\begin{array}{l}N D<3 \\
N D<3\end{array}$ & $\begin{array}{l}33.8 \\
38.8\end{array}$ & $\begin{array}{l}3.9 \\
2.9\end{array}$ & $\begin{array}{l}4.8 \mathrm{E}+01 \\
56 \mathrm{E}+01\end{array}$ & $\begin{array}{l}4.0 \mathrm{E}+00 \\
5.5 \mathrm{~F}+00\end{array}$ & $\begin{array}{l}1.1 \mathrm{E}-06 \\
1 . \mathrm{E}-06\end{array}$ & & & & $\begin{array}{r}7.5 \mathrm{E}-05 \\
8.4 \mathrm{E}-0.5\end{array}$ & $\begin{array}{l}2.8 \mathrm{E}-06 \\
2 . \mathrm{E}-06\end{array}$ & $\begin{array}{l}1.1 \mathrm{E}-02 \\
1\end{array}$ & $6.3 E-03$ \\
\hline $\begin{array}{l}\text { Pub670 } \\
\text { Pu671 }\end{array}$ & $\begin{array}{l}1.00 \\
0.99\end{array}$ & $\begin{array}{l}\begin{array}{l}45.88 \\
44.54\end{array}\end{array}$ & $\begin{array}{l}399.90 \\
405.87\end{array}$ & $\begin{array}{l}0.30 \\
0.30\end{array}$ & $\begin{array}{l}5.8 \\
5.7\end{array}$ & $\begin{array}{l}0.8 \\
0.6\end{array}$ & $\begin{array}{l}1.4 \\
1.4\end{array}$ & $\begin{array}{l}\mathrm{ND}<1 \\
\mathrm{ND}<1\end{array}$ & $\begin{array}{l}1.1 \\
1.1\end{array}$ & $\begin{array}{l}\mathrm{ND}<3 \\
\mathrm{ND}<3\end{array}$ & $\begin{array}{l}38.8 \\
23.8\end{array}$ & $\begin{array}{l}2.9 \\
1.8\end{array}$ & $\begin{array}{l}5.6 \mathrm{E}+01 \\
2.9 \mathrm{E}+01\end{array}$ & $\begin{array}{l}5.5 \mathrm{E}+00 \\
2.3 \mathrm{E}+00\end{array}$ & $\begin{array}{l}1.1 \mathrm{E}-06 \\
8.3 \mathrm{E}-07\end{array}$ & $\begin{array}{l}1.0 \mathrm{E}-06 \\
1.0 \mathrm{E}-06\end{array}$ & $\begin{array}{l}2.5 \mathrm{E}-06 \\
2.4 \mathrm{E}-06\end{array}$ & & $\begin{array}{l}8.4 \mathrm{E}-05 \\
5.0 \mathrm{E}-5\end{array}$ & $\begin{array}{l}2.1 \mathrm{E}-06 \\
1.2 \mathrm{E}-06\end{array}$ & $\begin{array}{l}1.2 \mathrm{E}-02 \\
6\end{array}$ & $\begin{array}{l}8.4 \mathrm{E}-03 \\
3.43\end{array}$ \\
\hline Pu672 & 0.99 & $\begin{array}{l}44.54 \\
46.26\end{array}$ & $\begin{array}{l}405.87 \\
419.89\end{array}$ & 0.30 & $\begin{array}{l}.11 \\
5.3\end{array}$ & $\begin{array}{l}0.6 \\
1.0\end{array}$ & $\begin{array}{l}1.4 \\
1.9\end{array}$ & $\begin{array}{l}\mathrm{N} U<1 \\
\mathrm{ND}<1\end{array}$ & $\begin{array}{l}4.1 \\
4.0\end{array}$ & $\begin{array}{l}\mathrm{N} D<3 \\
\mathrm{ND}<3\end{array}$ & $\begin{array}{l}23.8 \\
69.9\end{array}$ & $\begin{array}{l}1.8 \\
3.0\end{array}$ & $\begin{array}{l}2.9 \mathrm{E}+\mathrm{U} \\
3.8 \mathrm{E}+01\end{array}$ & $\begin{array}{l}2.3+00 \\
8.7 E+00\end{array}$ & $\begin{array}{l}8.3 \mathrm{E}-0 / \\
1.5 \mathrm{E}-06\end{array}$ & $\begin{array}{l}1.0 E-06 \\
1.4 E-06\end{array}$ & $\begin{array}{l}2.4 \mathrm{E}-06 \\
9.0 \mathrm{E}-06\end{array}$ & & $\begin{array}{l}5.0 \mathrm{E}-05 \\
1.5 \mathrm{E}-04\end{array}$ & $\begin{array}{l}1.2 \mathrm{E}-06 \\
2.2 \mathrm{E}-06\end{array}$ & $\begin{array}{l}6.2 \mathrm{E}-03 \\
8.3 \mathrm{E}-03\end{array}$ & $\begin{array}{l}3.4 \mathrm{~A}=03 \\
1 . \mathrm{E}-02\end{array}$ \\
\hline Pu673 & 0.99 & 49.38 & 433.94 & 0.30 & 5.8 & 0.4 & $N D<1$ & $N D<1$ & $\mathrm{ND}<1$ & $\mathrm{ND}<3$ & 40.3 & 4.0 & $4.0 \mathrm{E}+01$ & $5.8 \mathrm{E}+00$ & $6.1 \mathrm{E}-07$ & & & & $9.4 \mathrm{E}-05$ & $3.1 \mathrm{E}-06$ & $9.4 \mathrm{E}-03$ & $9.6 \mathrm{E}-03$ \\
\hline Pu674 & 0.99 & 48.81 & 447.89 & 0.30 & 5.8 & 0.4 & 1.1 & $N D<1$ & $N D<1$ & $N D<3$ & 19.9 & 3.9 & $3.6 \mathrm{E}+01$ & $2.4 \mathrm{E}+00$ & $5.8 \mathrm{E}-07$ & $8.6 \mathrm{E}-07$ & & & 4.6E-05 & $3.0 \mathrm{E}-06$ & $8.3 \mathrm{E}-03$ & 3.9E-03 \\
\hline $\begin{array}{l}\text { Pu675 } \\
\text { Puf66 }\end{array}$ & 0.99 & 48.26 & 460.90 & 0.30 & 5.2 & 0.5 & $N D<1$ & $N D<1$ & $N D<1$ & $N D<3$ & 37.2 & 4.0 & $4.1 E+01$ & $3.5 \mathrm{E}+00$ & $7.0 \mathrm{E}-07$ & & & & $8.5 \mathrm{E}-05$ & $3.0 \mathrm{E}-06$ & $9.3 \mathrm{E}-03$ & $5.7 \mathrm{E}-03$ \\
\hline Pu676 & 0.99 & 49.96 & 477.89 & 0.30 & 5.9 & 0.4 & $N D<1$ & $N D<1$ & $N D<1$ & $\mathrm{ND}<3$ & 61.4 & 1.8 & $9.6 \mathrm{E}+01$ & $6.6 \mathrm{E}+00$ & $6.4 \mathrm{E}-07$ & & & & 1.4E-04 & $1.4 \mathrm{E}-06$ & $2.3 \mathrm{E}-02$ & 1.1E-02 \\
\hline Pu677 & 0.99 & 49.19 & 485.90 & 0.30 & 5.9 & 0.4 & & & & & & & & & $5.8 \mathrm{E}-07$ & & & & & & & \\
\hline Pu678 & 0.99 & 35.84 & 503.38 & 0.30 & 5.9 & 0.9 & & & & & & & & & $1.1 \mathrm{E}-06$ & & & & & & & \\
\hline Pu679 & 0.99 & 40.64 & 511.38 & 0.30 & 6.0 & 0.8 & & & & & & & & & $9.8 \mathrm{E}-07$ & & & & & & & \\
\hline Pu680 & 0.99 & 40.42 & 531.48 & 0.30 & 6.0 & 0.9 & & & & & & & & & $1.1 \mathrm{E}-06$ & & & & & & & \\
\hline $\begin{array}{l}\text { Pu681 } \\
\text { Puge? }\end{array}$ & 0.99 & $\begin{array}{l}41.92 \\
30.70\end{array}$ & $\begin{array}{r}553.39 \\
575.3\end{array}$ & 0.30 & 6.1 & 0.7 & & & & & & & & & $8.8 \mathrm{E}-07$ & & & & & & & \\
\hline $\begin{array}{l}\text { Pu682 } \\
\text { Pu683 }\end{array}$ & 0.99 & $\begin{array}{l}39.70 \\
\end{array}$ & 575.38 & 0.30 & 5.8 & 0.6 & & & & & & & & & $7.9 \mathrm{E}-07$ & & & & & & & \\
\hline $\begin{array}{l}\text { Pu683 } \\
\text { Pug64 }\end{array}$ & 0.99 & $\begin{array}{l}139.37 \\
42.23\end{array}$ & $\begin{array}{l}603.93 \\
624.40\end{array}$ & 0.30 & $\begin{array}{l}5.8 \\
5.9\end{array}$ & 0.3 & & & & & & & & & $\begin{array}{l}1.5 \mathrm{E}-06 \\
7\end{array}$ & & & & & & & \\
\hline $\begin{array}{l}\text { Pub64 } \\
\text { Pu685 }\end{array}$ & $\begin{array}{l}0.99 \\
0.99\end{array}$ & $\begin{array}{l}4.23 \\
45.98\end{array}$ & $\begin{array}{l}624.40 \\
657.34\end{array}$ & $\begin{array}{l}0.30 \\
0.30\end{array}$ & $\begin{array}{l}5.9 \\
5.9\end{array}$ & $\begin{array}{l}0.5 \\
0.6\end{array}$ & & & & & & & & & $\begin{array}{l}7.3 \mathrm{E}-07 \\
9.5 \mathrm{E}-07\end{array}$ & & & & & & & \\
\hline Pu686 & 0.99 & 44.66 & 679.42 & 0.30 & 5.9 & 0.6 & & & & & & & & & $9.3 \mathrm{E}-07$ & & & & & & & \\
\hline \multirow{2}{*}{\multicolumn{23}{|c|}{$\begin{array}{l}\text { (b) Ce-U Ceramic 25 C } \\
\text { Experiments Started on: }\end{array}$}} \\
\hline & & & & & & & & & & & & & & & & & & & & & & \\
\hline U & $7 / 10 / 0$ & 1 11:00 & & & & & & & & & & & & & & & & & & & & \\
\hline U-Ce-Ti-Ca C & Ceramic & BATCH = & $\begin{array}{l}\mathrm{P} 133 \\
\mathrm{~m}^{\wedge} 2 / \mathrm{g}\end{array}$ & & & & & & & & & & & & & & & & & & & \\
\hline Star & arting $S A=$ & $\begin{array}{l}0.10 \\
5.00\end{array}$ & $\begin{array}{l}m^{\wedge} / \mathrm{g} \\
\mathrm{g} / \mathrm{c}^{\wedge} 3\end{array}$ & & & & & & & & & & & & & & & & & & & \\
\hline & density $=$ & $\begin{array}{c}5.00 \\
5.00 E-12\end{array}$ & $\begin{array}{l}\mathrm{g} / \mathrm{g} \mathrm{m}^{\wedge} 3 \\
\mathrm{~s} / \mu^{\wedge} 3\end{array}$ & & & & & & & & & & & & & & & & & & & \\
\hline & Element & VtFracElement & it & & & & & & & & & & & & & & & & & & & \\
\hline & U & 0.256 & & & & & & & & & & & & & & & & & & & & \\
\hline & Ce & 0.075 & & & & & & & & & & & & & & & & & & & & \\
\hline & $\mathrm{Ca}$ & 0.086 & & & & & & & & & & & & & & & & & & & & \\
\hline & $\mathrm{Ti}$ & 0.206 & & & & & & & & & & & & & & & & & & & & \\
\hline & $\mathrm{Hf}$ & 0.096 & & & & & & & & & & & & & & & & & & & & \\
\hline $25 \mathrm{C}$ data & Mass & Flow Rate & Run time & SurfArea & & & & & & & & & & & & & & & & & & \\
\hline $\mathrm{pH} 2$ & (g) & (mL/day) & (days) & (sq. m) & $\mathrm{pH}$ & u & $\mathrm{Ce}$ & $\mathrm{Ca}$ & $\mathrm{Ti}$ & $\mathrm{Hf}$ & NR-U & NR-Ce & NR-Ca & NR-Ti & NR-Hf & & & & & & & \\
\hline start & 1.54 & & & 0.15 & 2.2 & $\mathrm{ppb}$ & $\mathrm{ppb}$ & $\mathrm{ppb}$ & $\mathrm{ppb}$ & ppb & $g / m^{\wedge} / 2 d d a y$ & $\mathrm{~g} / \mathrm{m}^{\wedge} 2 /$ day & $/ \mathrm{m} \wedge^{\wedge} 2 /$ day & $\mathrm{g} / \mathrm{m}^{\wedge} 2 / \mathrm{day}$ & $\mathrm{g} / \mathrm{m}^{\wedge} 2 / \mathrm{day}$ & & & & & & & \\
\hline U201 & 1.54 & 19.44 & 0.52 & 0.15 & 2.2 & 2600.00 & 9400.00 & 18800 & 110.00 & & $1.3 \mathrm{E}-03$ & $1.6 \mathrm{E}-02$ & $2.8 \mathrm{E}-02$ & $6.9 \mathrm{E}-05$ & & & & & & & & \\
\hline U202 & 1.54 & 19.90 & 2.13 & 0.15 & 2.1 & 790.00 & 390.00 & 540.00 & 310.00 & & 4.1E- 04 & $6.9 \mathrm{E}-04$ & $8.3 \mathrm{E}-04$ & $2.0 \mathrm{E}-04$ & & & & & & & & \\
\hline U203 & 1.54 & 20.22 & 5.42 & 0.15 & 2.1 & 280.00 & 170.00 & 190.00 & 180.00 & & $1.5 \mathrm{E}-04$ & 3.0E-04 & 3.0E-04 & $1.2 \mathrm{E}-04$ & & & & & & & & \\
\hline U204 & 1.54 & 20.20 & 7.47 & 0.15 & 2.1 & 210.00 & 120.00 & 140.00 & 150.00 & & 1.1E-04 & 2.1E-04 & 2.2E-04 & $9.8 \mathrm{E}-05$ & & & & & & & & \\
\hline $\begin{array}{l}\text { U205 } \\
\text { U206 }\end{array}$ & $\begin{array}{l}1.54 \\
1.54\end{array}$ & $\begin{array}{l}20.63 \\
20.33\end{array}$ & $\begin{array}{r}9.13 \\
12.39\end{array}$ & 0.15 & 2.1 & $\begin{array}{l}180.00 \\
150.00\end{array}$ & 100.00 & 120.00 & 130.00 & & $9.7 \mathrm{E}-05$ & $1.8 \mathrm{E}-04$ & $\begin{array}{l}1.9 \mathrm{E}-04 \\
1.5-04\end{array}$ & $\begin{array}{l}8.7 \mathrm{~F}-05 \\
\end{array}$ & & & & & & & & \\
\hline $\begin{array}{l}\text { U206 } \\
\text { U207 }\end{array}$ & $\begin{array}{r}1.54 \\
1.54\end{array}$ & $\begin{array}{l}20.33 \\
21.42\end{array}$ & $\begin{array}{l}12.39 \\
14.38\end{array}$ & $\begin{array}{l}0.15 \\
0.15\end{array}$ & $\begin{array}{l}2.1 \\
2.1\end{array}$ & $\begin{array}{l}150.00 \\
150.00\end{array}$ & $\begin{array}{l}80.00 \\
80.00\end{array}$ & 90.00 & 100.00 & & $\begin{array}{l}7.9 \mathrm{E}-05 \\
8.4 \mathrm{E}-05\end{array}$ & $\begin{array}{l}1.4 \mathrm{E}-04 \\
15 \mathrm{E}-04\end{array}$ & $\begin{array}{l}1.4 E-04 \\
1.5 E-04\end{array}$ & $\begin{array}{l}6.6 \mathrm{E}-05 \\
6 \mathrm{E}-05\end{array}$ & & & & & & & & \\
\hline U208 & $\begin{array}{l}1.54 \\
1.54\end{array}$ & $\begin{array}{l}\begin{array}{l}21.42 \\
21.35\end{array} \\
2.55\end{array}$ & $\begin{array}{l}\begin{array}{l}44.38 \\
16.15\end{array}\end{array}$ & $\begin{array}{l}0.15 \\
0.15\end{array}$ & $\begin{array}{l}2.1 \\
2.1\end{array}$ & $\begin{array}{l}150.00 \\
119.00\end{array}$ & $\begin{array}{l}80.00 \\
65.00\end{array}$ & $\begin{array}{l}90.00 \\
74.00\end{array}$ & $\begin{array}{l}1000.00 \\
118.00\end{array}$ & 0.03 & $\begin{array}{l}8.4-05 \\
6.6 \mathrm{E}-05\end{array}$ & $\begin{array}{l}1.5 \mathrm{E}-04 \\
1.2 \mathrm{E}-04\end{array}$ & $\begin{array}{l}\text { 1.5E-04 } \\
1.2 \mathrm{E}-04\end{array}$ & $\begin{array}{l}6.9 \mathrm{E}-05 \\
8.2 \mathrm{E}-05\end{array}$ & 4.4E-08 & & & & & & & \\
\hline U209 & $\begin{array}{l}1.54 \\
1.54\end{array}$ & 21.70 & $\begin{array}{l}10.07 \\
19.07\end{array}$ & 0.15 & 2.0 & 101.00 & 53.00 & 57.00 & 97.00 & 0.02 & 5.7E-05 & $1.0 \mathrm{E}-04$ & $\begin{array}{l}9.6 \mathrm{E}-05 \\
9\end{array}$ & $\begin{array}{l}0.8 \mathrm{E}-05 \\
6.05\end{array}$ & $30 \mathrm{E}-08$ & & & & & & & \\
\hline U210 & 1.54 & 21.85 & 21.07 & 0.15 & 2.1 & 96.00 & 51.00 & 63.00 & 95.00 & & $5.5 \mathrm{E}-05$ & $9.9 \mathrm{E}-05$ & 1.1. $\mathrm{E}-04$ & $6.7 \mathrm{E}-05$ & & & & & & & & \\
\hline U211 & 1.54 & 22.10 & 23.08 & 0.15 & 2.1 & 99.00 & 50.00 & 50.00 & 86.00 & & $5.7 \mathrm{E}-05$ & $9.8 \mathrm{E}-05$ & $8.5 \mathrm{E}-05$ & $6.2 \mathrm{E}-05$ & & & & & & & & \\
\hline U212 & 1.54 & 22.38 & 26.07 & 0.15 & 2.1 & 83.00 & 41.00 & 43.00 & 73.00 & & $4.8 \mathrm{E}-05$ & $8.1 \mathrm{E}-05$ & 7.4E-05 & $5.3 \mathrm{E}-05$ & & & & & & & & \\
\hline
\end{tabular}

Page 41 
SPFT Data Table

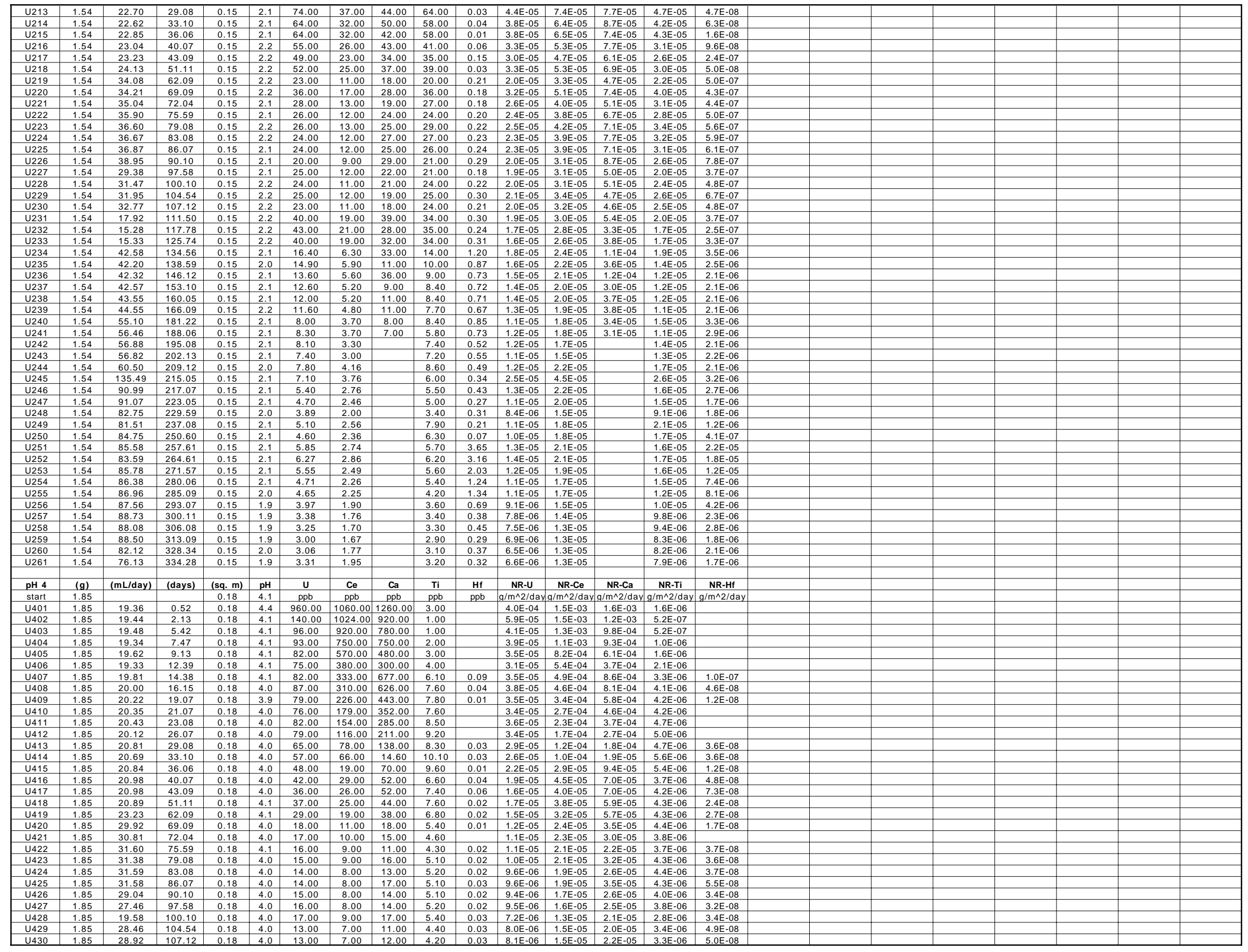

Page 42 
SPFT Data Table

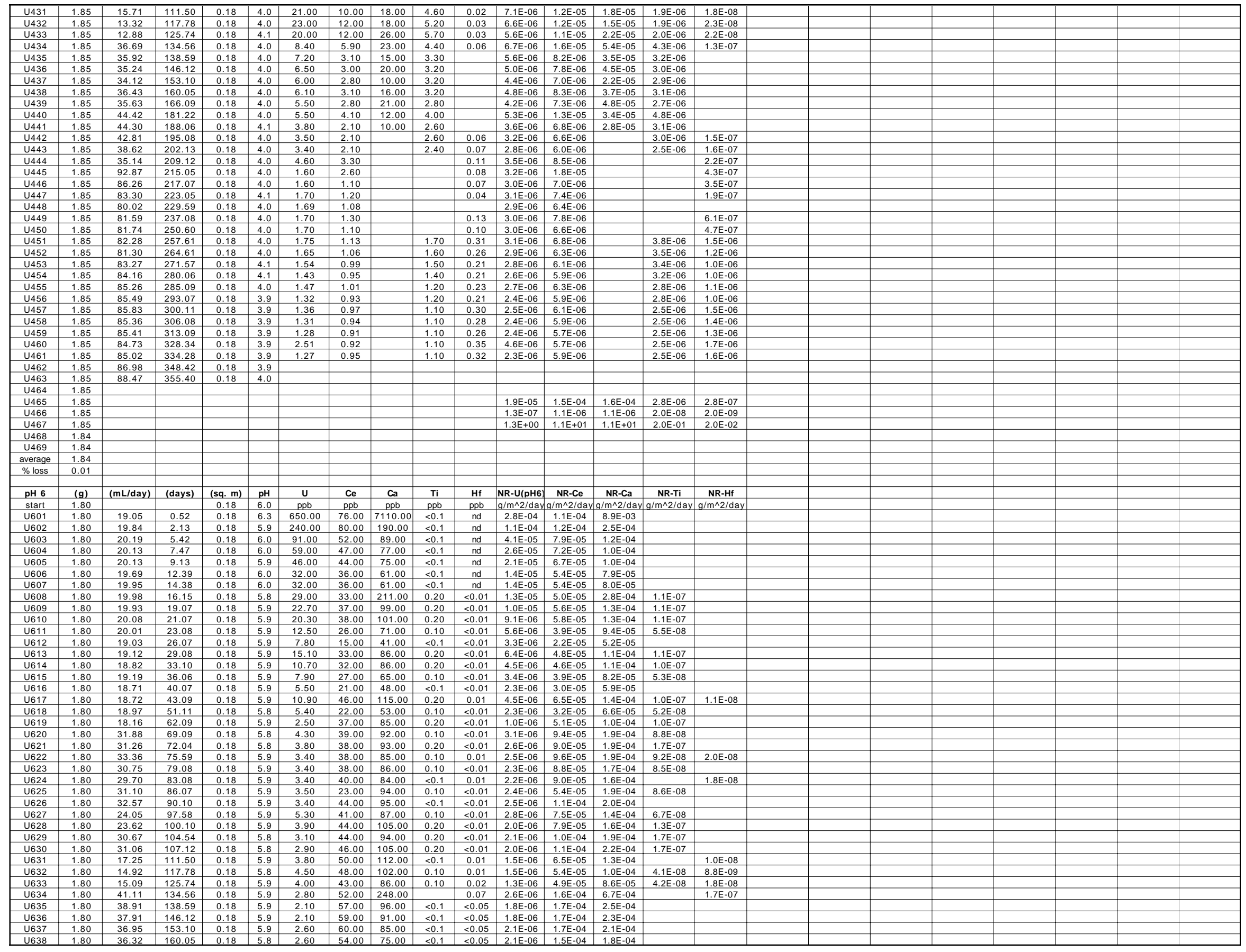


SPFT Data Table

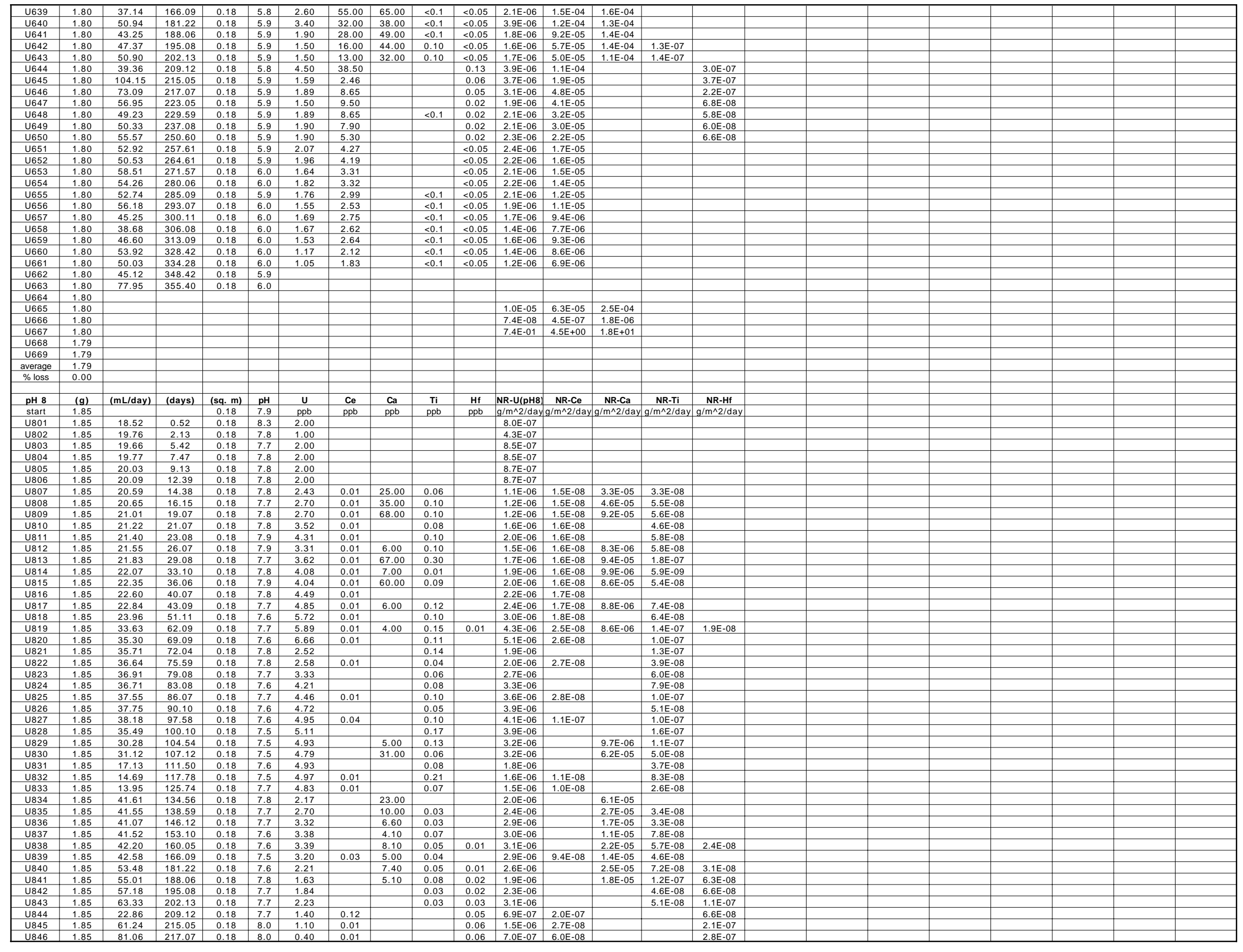

Page 44 
SPFT Data Table

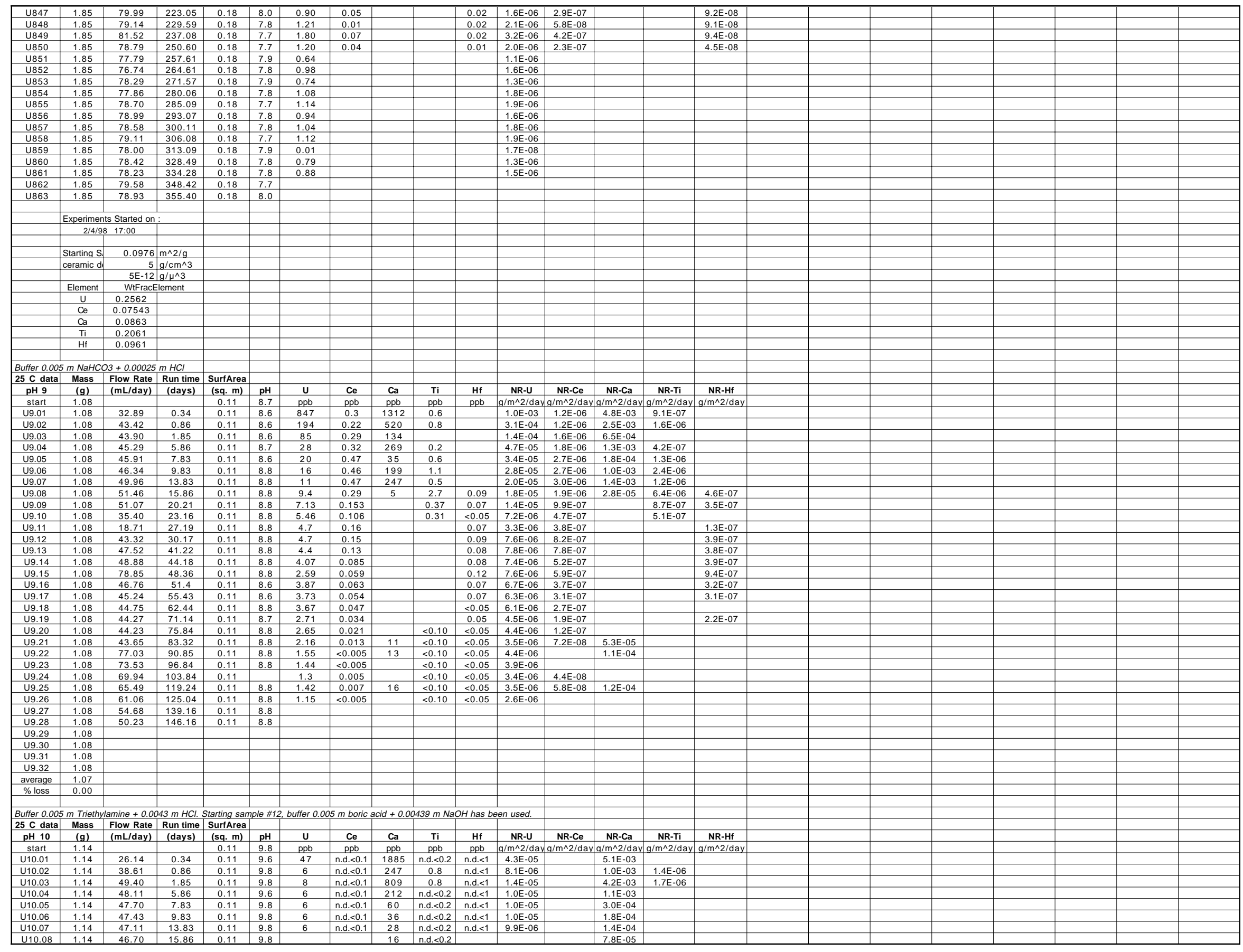


SPFT Data Table

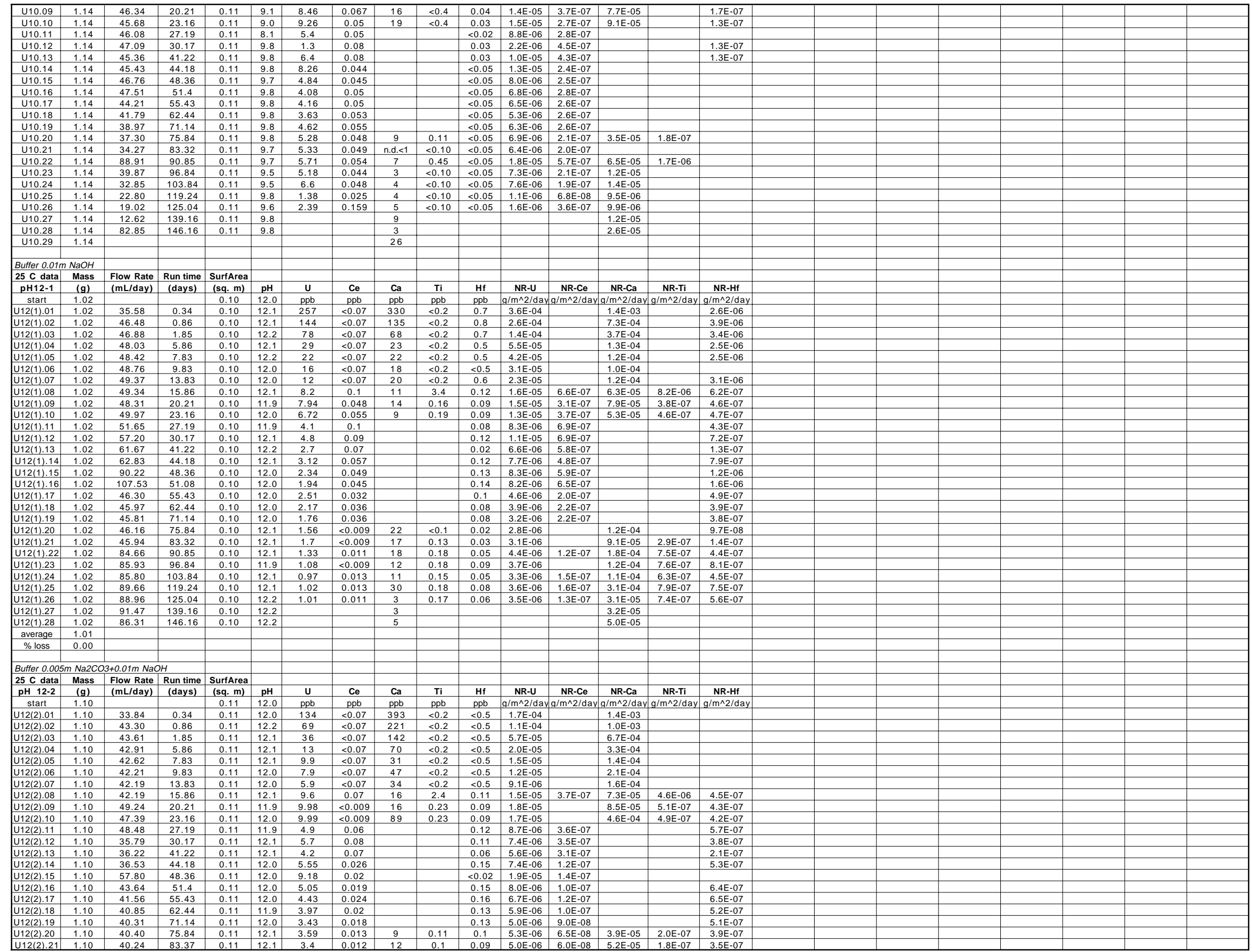

Page 46 
SPFT Data Table

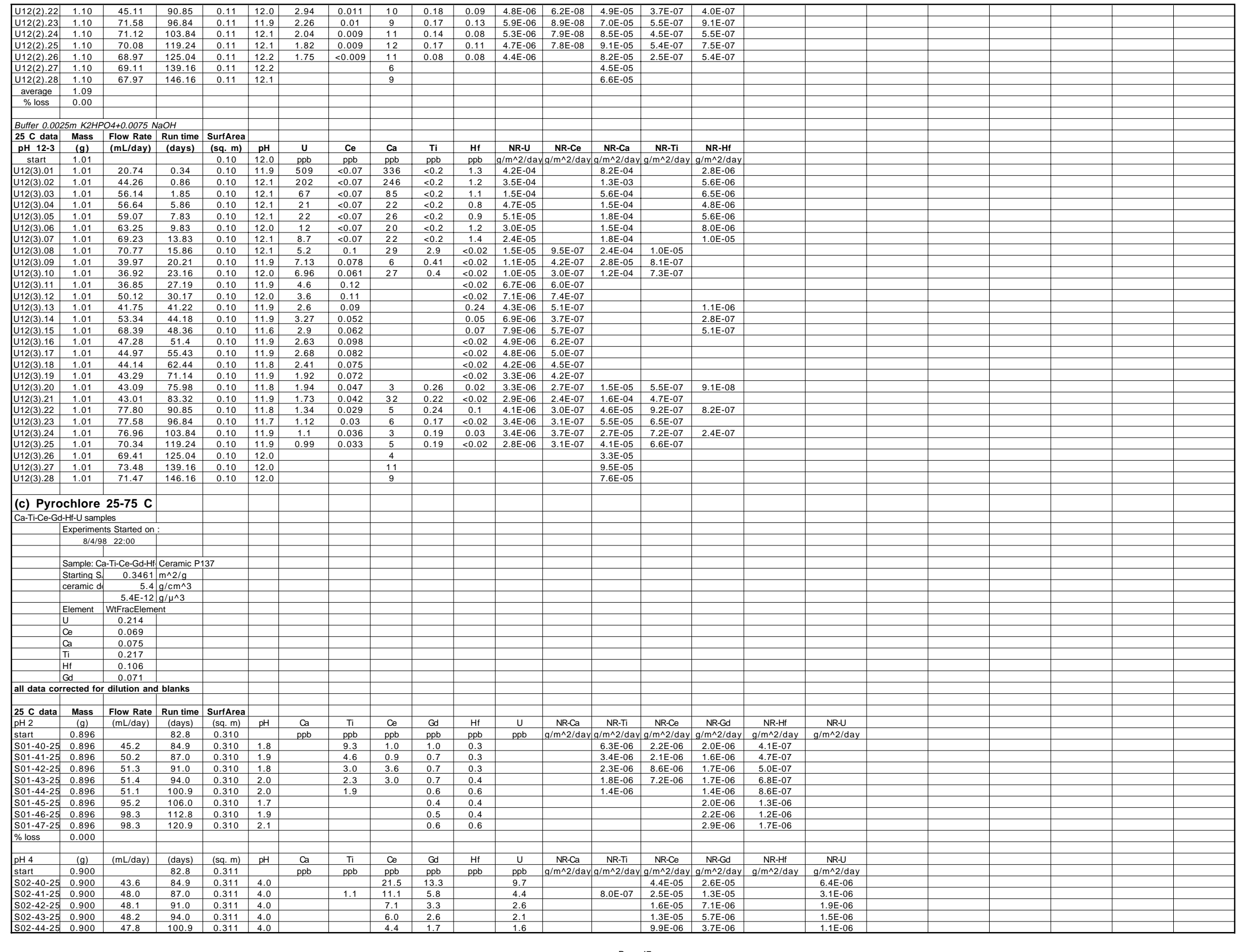


SPFT Data Table

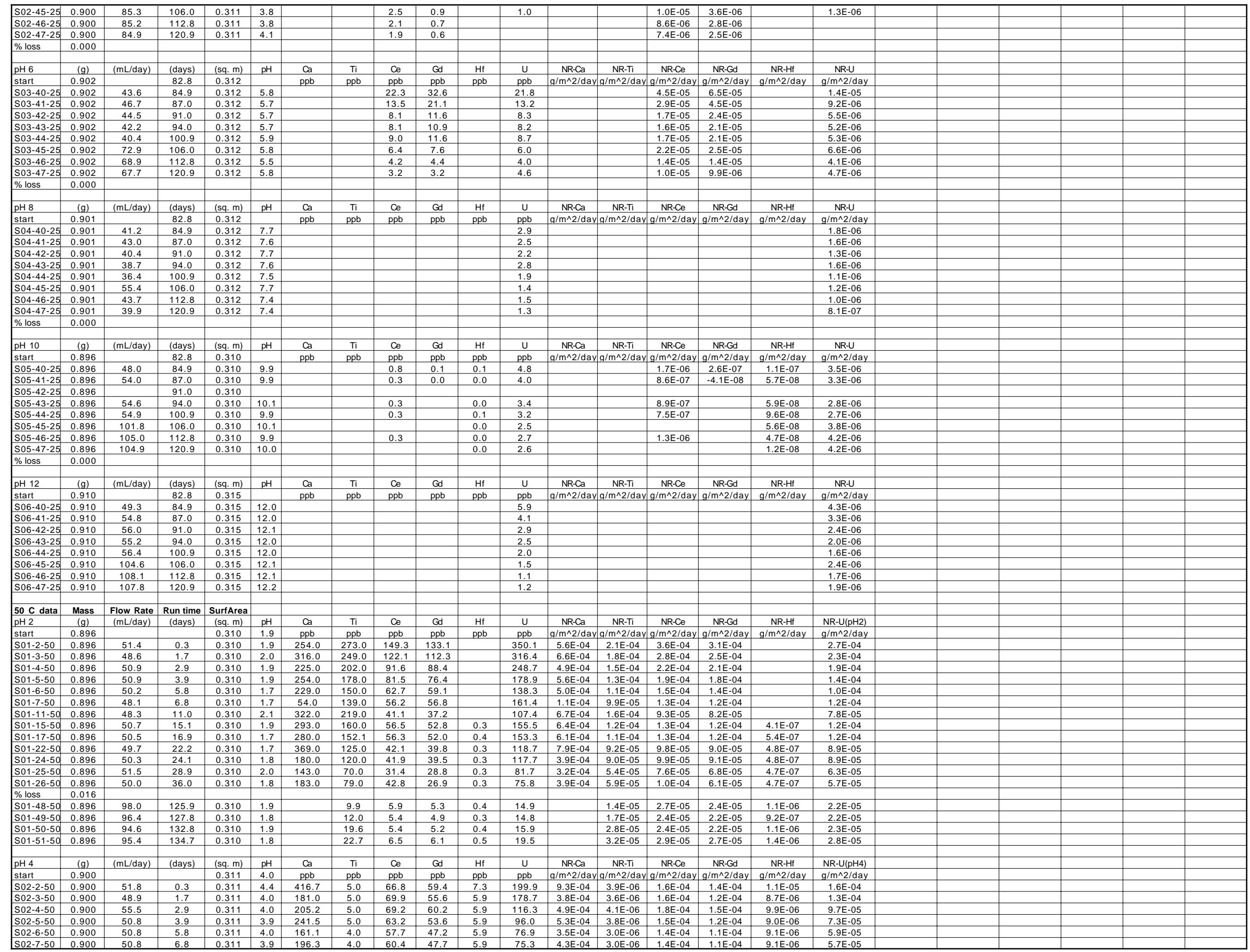

Page 48 
SPFT Data Table

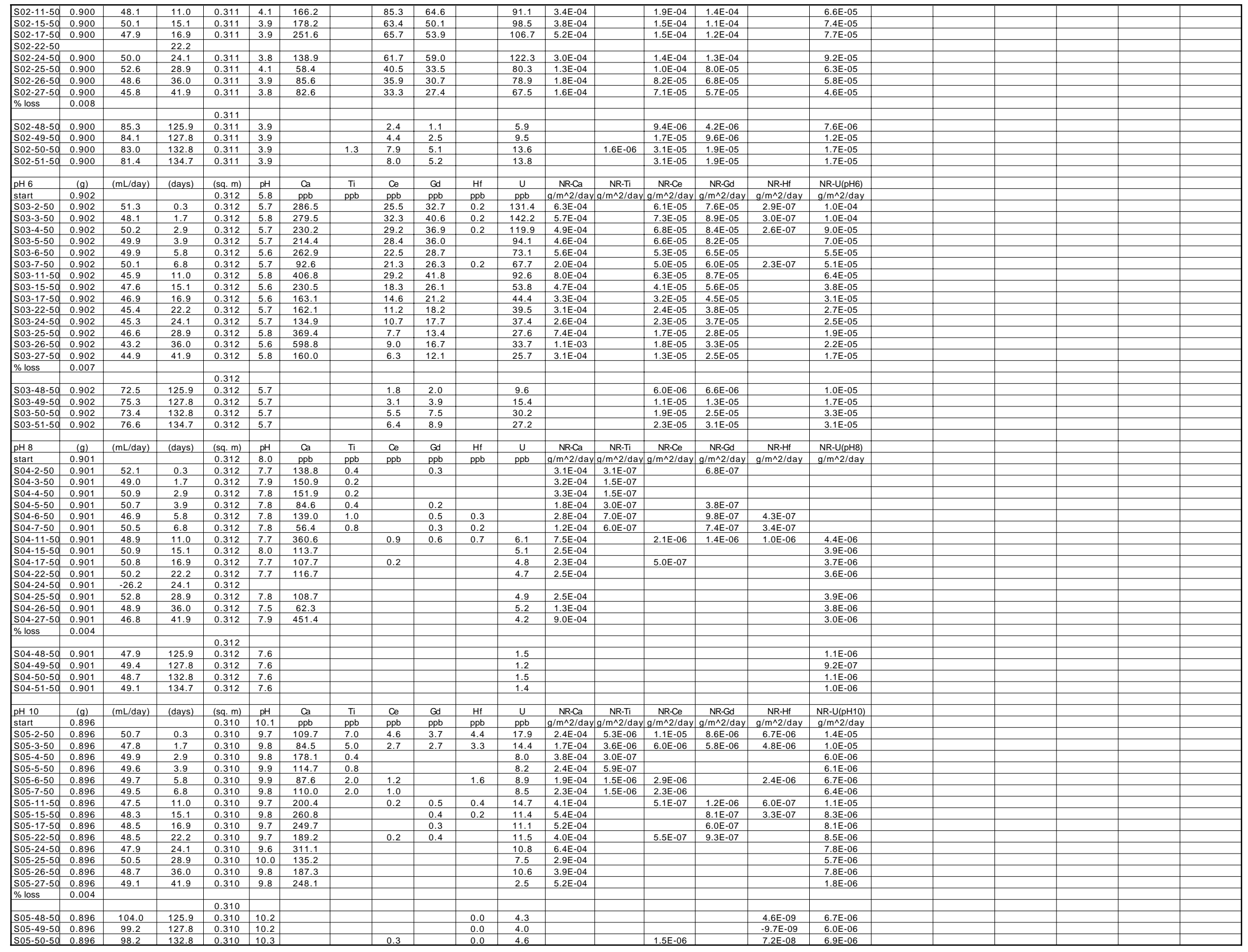


SPFT Data Table

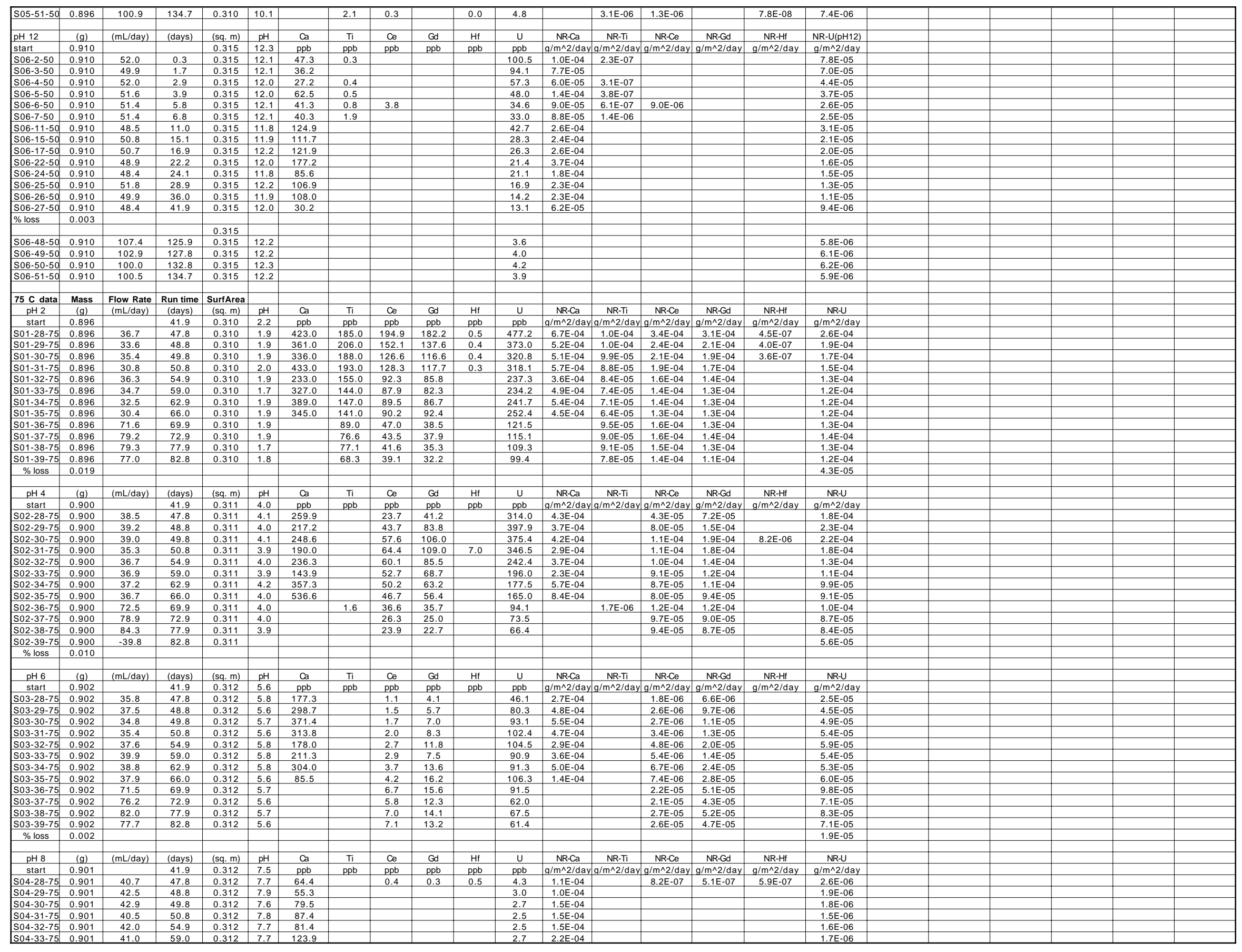


SPFT Data Table

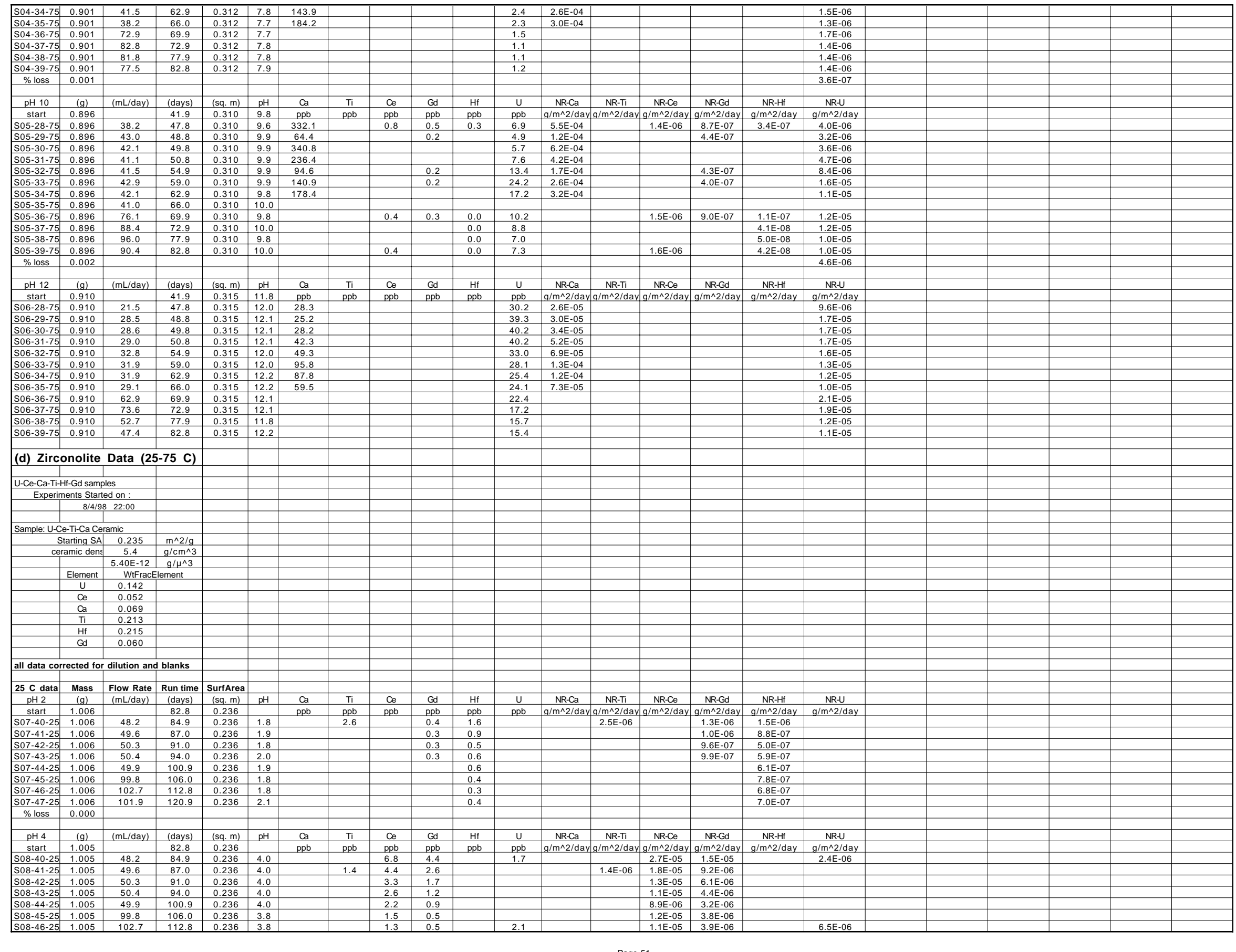


SPFT Data Table

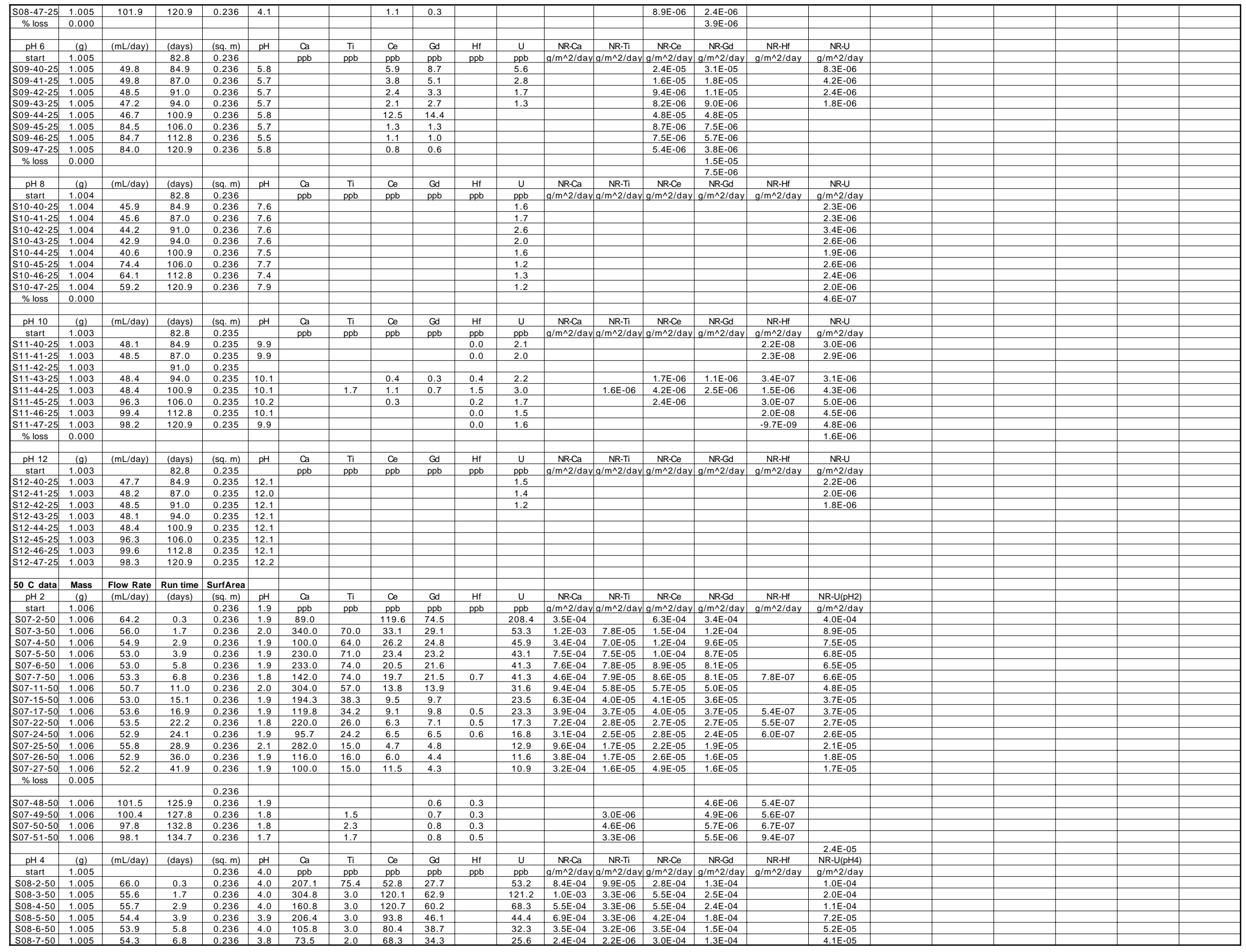

Page 52 
SPFT Data Table

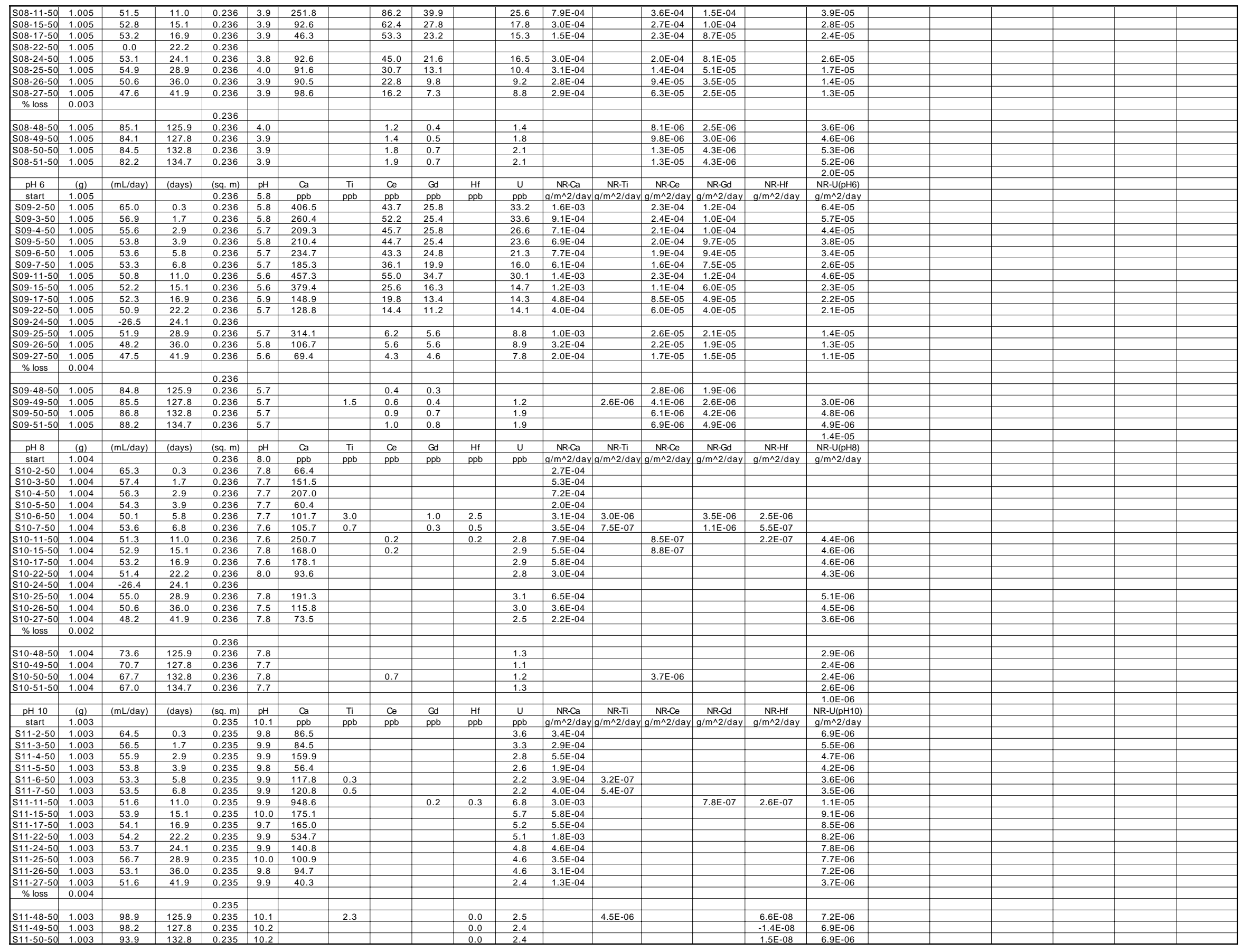


SPFT Data Table

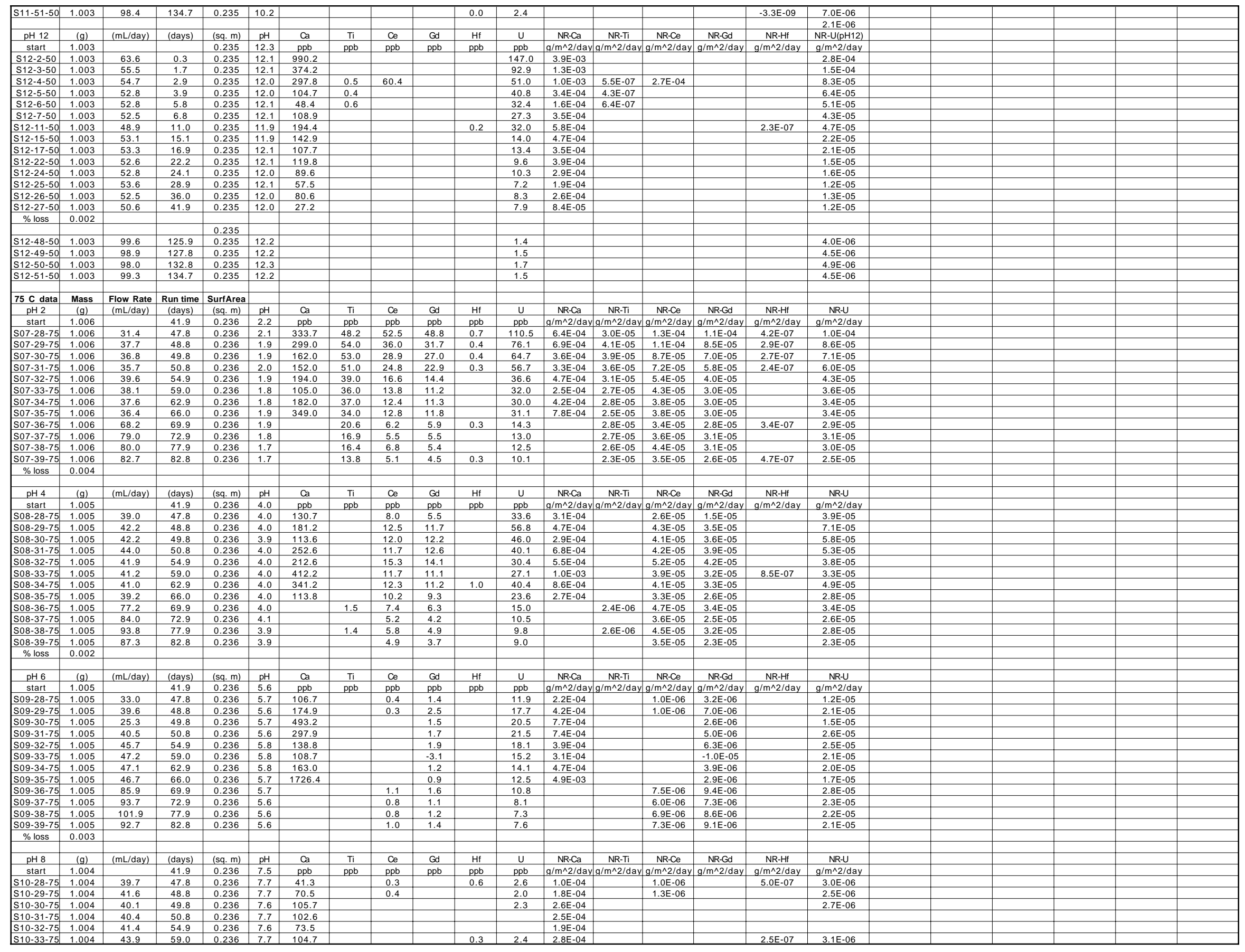


SPFT Data Table

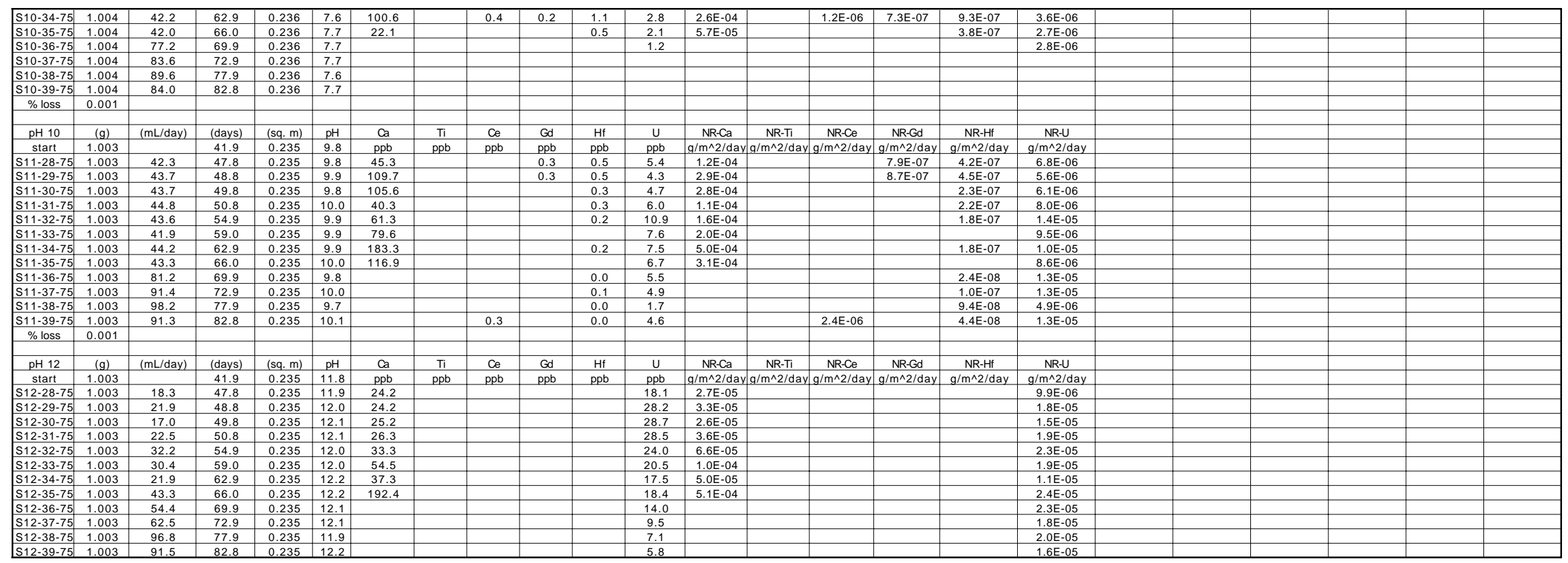

